DEPARTMENT OF THE INTERIOR

UNITED STATES GEOLOYICAL SURVEY

GEORGE OTIS SMTTH, DTRECTOR

WATER-SUPPLY PAPER 220

GEOLOGY AND WATER RESOURCES

OF

A PORTION OF SOUTH-CENTRAL OREG0N

BY

GERAID A. WARING

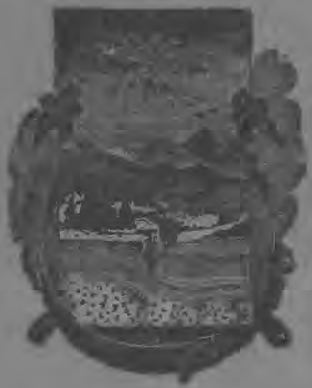

WASHINGTON

GOVERNMENT PRINTING OFFICE

1908 
DEPARTMENT OF THE INTERIOR

UNITED STATES GEOLOGICAL SURVEY

GEORGE OTIS SMITH, DIRECTOR

WAter-SuppLy PAPER 220

GEOLOGY AND WATER RESOURCES

OF

\section{A PORTION OF SOUTH-CENTRAL OREGON}

BY

GERALD A. WARING

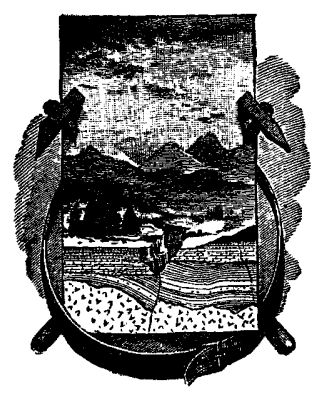

WASHINGTON

GOVERNMENT PRINTING OFFICE

1908 



\section{CONTENTS.}

Introduction

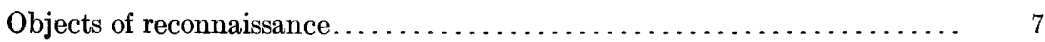

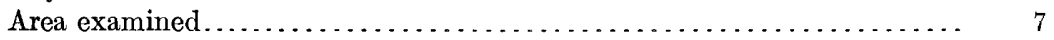

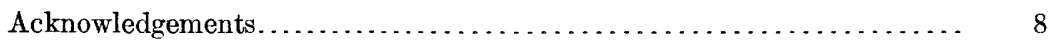

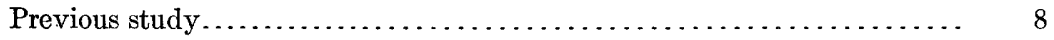

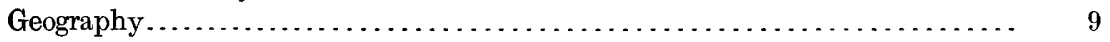

General features.......................................... 9

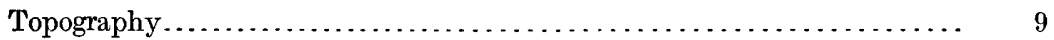

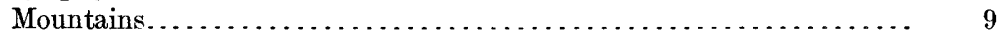

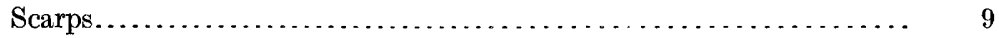

Minor features...................................... 10

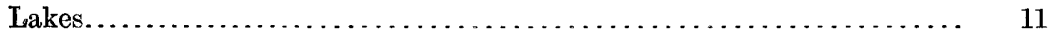

Character of the lakes.................................... 12

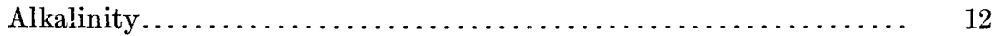

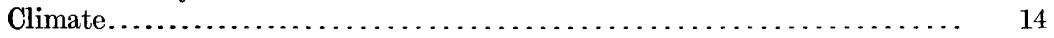

General conditions......................................... 14

Temperature and rainfall records......................... 15

Vegetation................................................ 16

Animal life................................................. 17

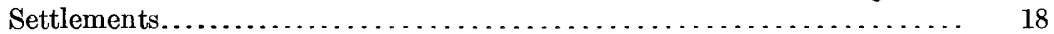

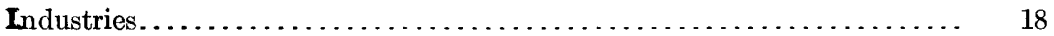

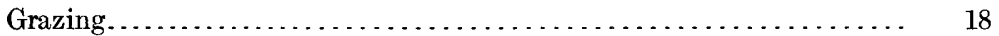

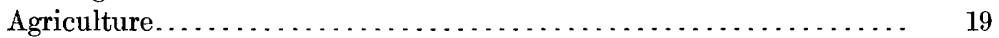

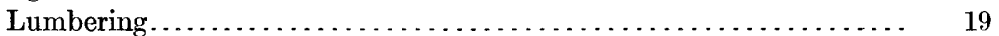

Mining.............................................. 20

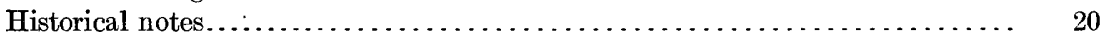

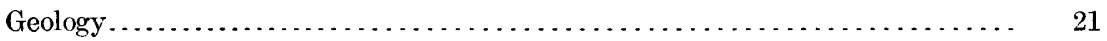

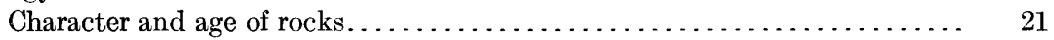

Classes of rocks...................................... ${ }_{2} 22$

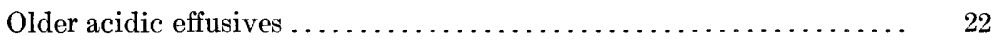

Older basaltic effusives.................................... 23

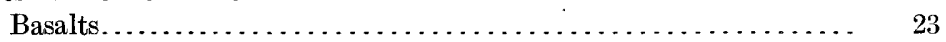

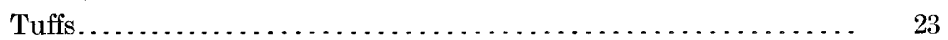

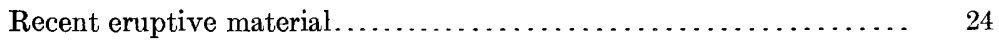

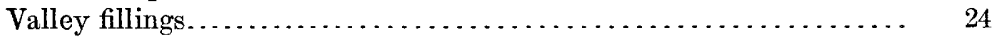

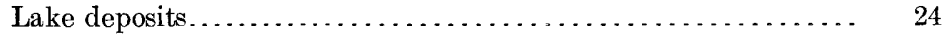

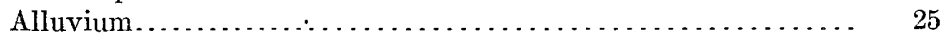

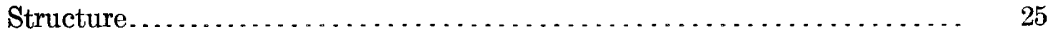

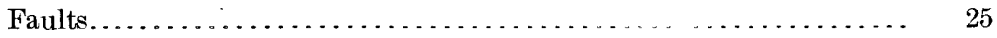

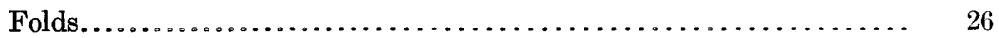


Geology-Continued. Page.

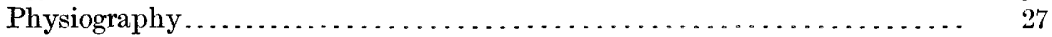

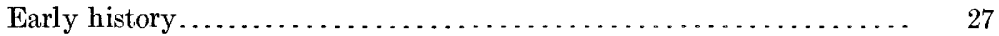

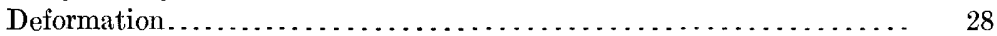

Preservation of deformational features..................... 29

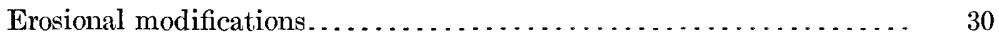

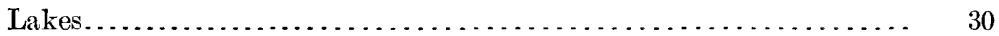

Present lakes......................................... 30

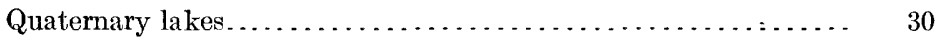

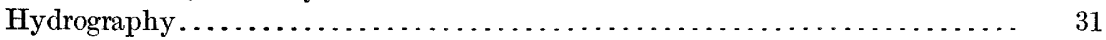

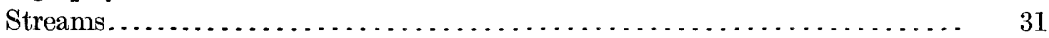

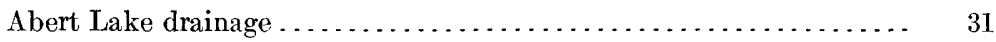

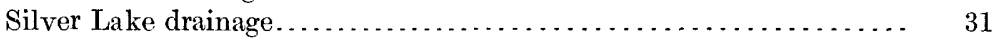

Sprague River drainage................................ 32

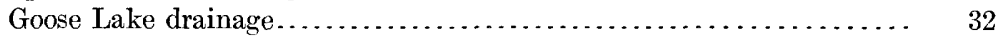

Summer Lake Basin...................................... 32

Warner Valley streams................................... 32

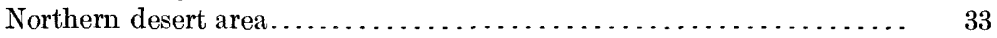

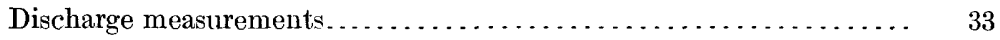

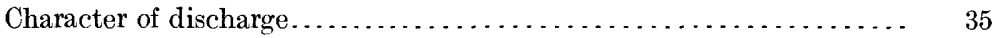

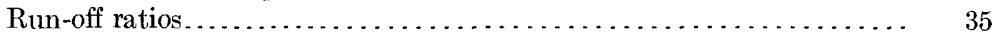

Effect of forests......................................... 36

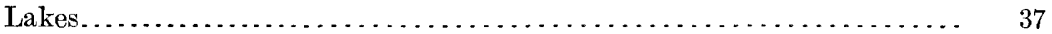

Changes in surface level.............................. 37

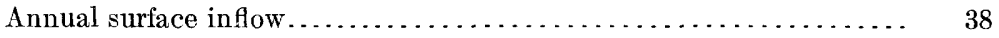

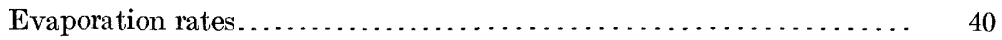

Subsurface inflow to Goose Lake........................ 42

Hydrology ..................................................... 43

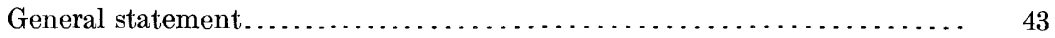

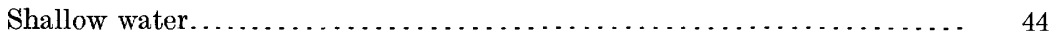

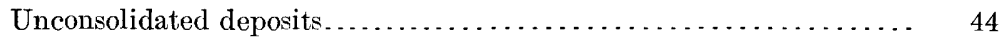

Thickness and processes of formation ................... 44

Ground-water level.................................. 44

Artesian couditions in lake and stream deposits............... 45

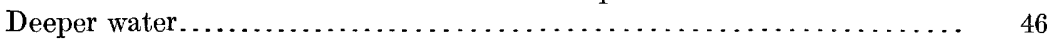

Conditions of occurrence............................. 46

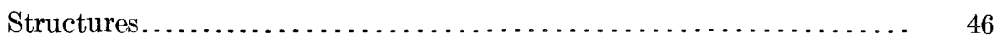

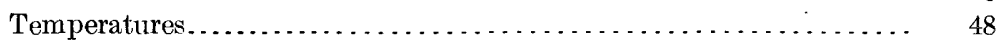

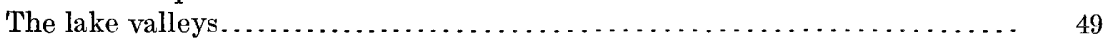

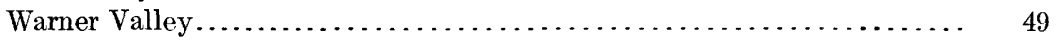

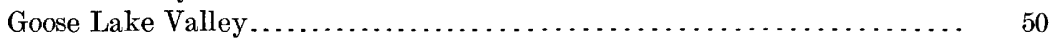

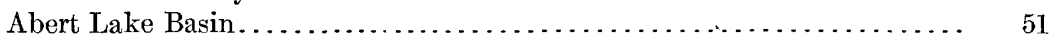

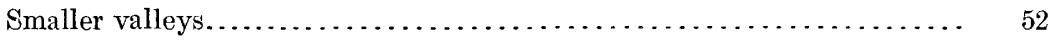

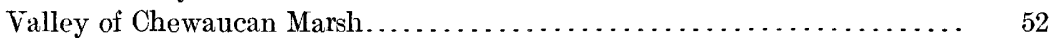

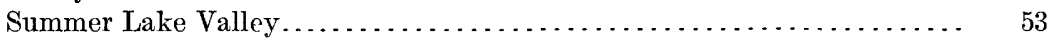

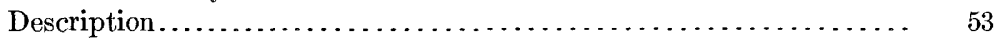

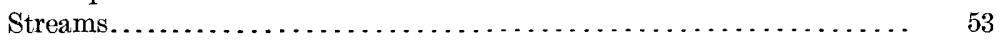

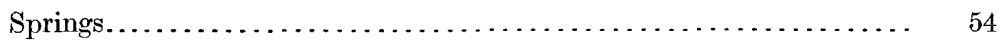

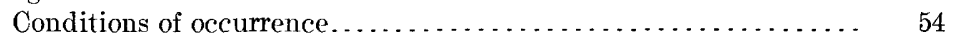

Origin of the Ana River springs........................ 55

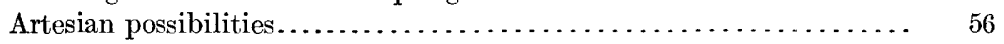

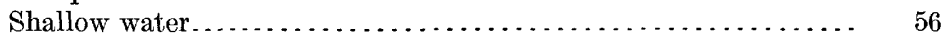

Deep water...................................... 57 
The lake valleys-Continued.

Silver Lake Valley..................................... 57

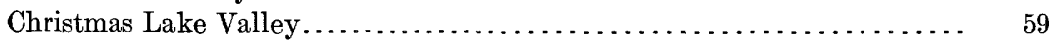

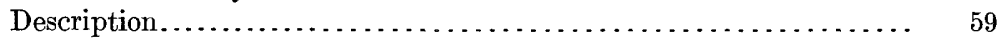

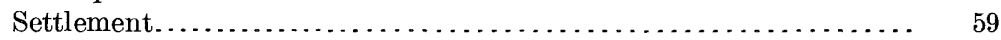

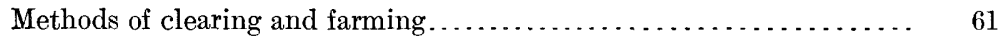

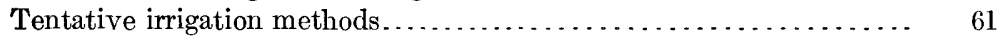

Desert claims................................... 61

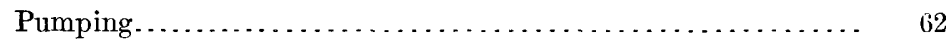

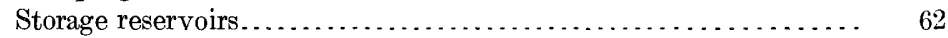

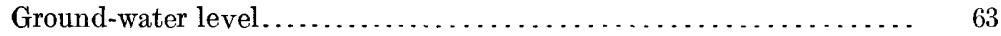

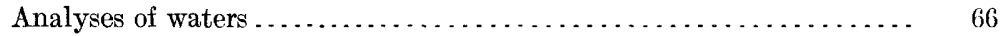

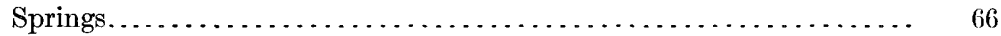

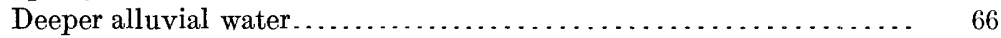

Rock water........................................... 67

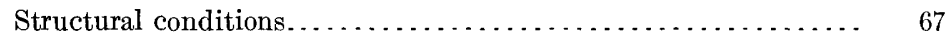

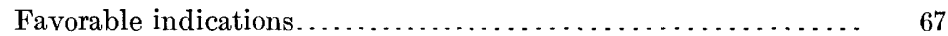

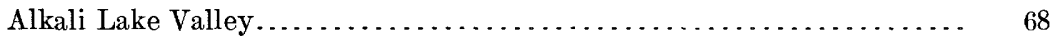

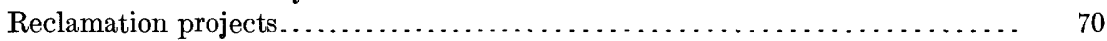

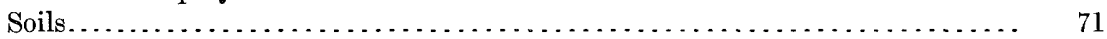

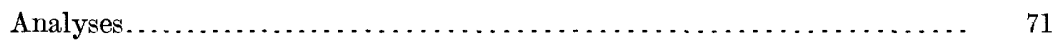

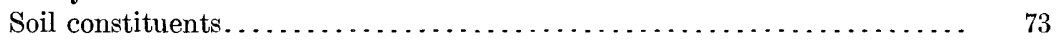

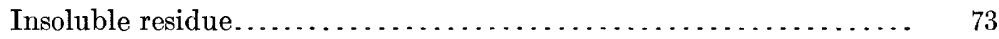

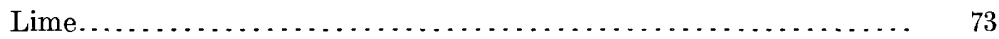

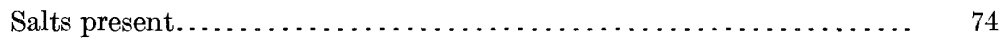

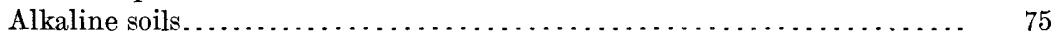

The alkalies and their effects............................ 75

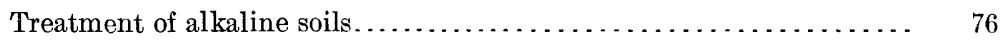

Conditions in Lake County................................. 78

Crops adaptable to alkaline soils......................... 78

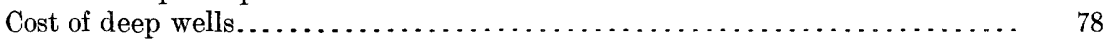

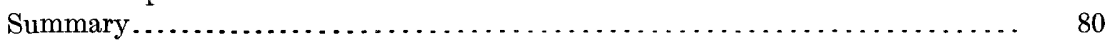

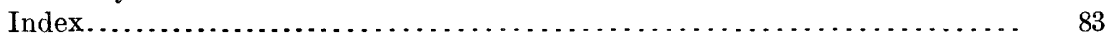

\section{ILLUSTRATIONS.}

Plate I. Index map showing location of area discussed................. 7

II. Reconnaissance topographic map of south-central Oregon .... In pocket.

III. $A$, Typical sink in high desert near Alkali Lake; $B$, Hillocks near

Alkali Lake; $C$, Alkaline pools in Christmas Lake Valley....... 10

IV. Scarp and landslide area near south end of Lake Abert .......... 12

V. Lakeview, Oreg., from the north....................... 18

VI. Reconnaissance geologic map of south-central Oregon........ In pocket.

VII. $A$, Fort Rock, from the southeast; $B$, Alkali Lake, from the north.. $\quad 26$

VIII. Sketch of Lake Abert, from the southeast ................. 50

IX. $A$, Sagebrush in Christmas Lake Valley; $B$, Area in Christmas Lake

Valley, cleared by burning; $C$, Sand Springs............... 58

X. Approximate geologic cross sections ........................ 66

Fig. 1. Map of Christmas Lake Valley, showing area filed on............. 60 



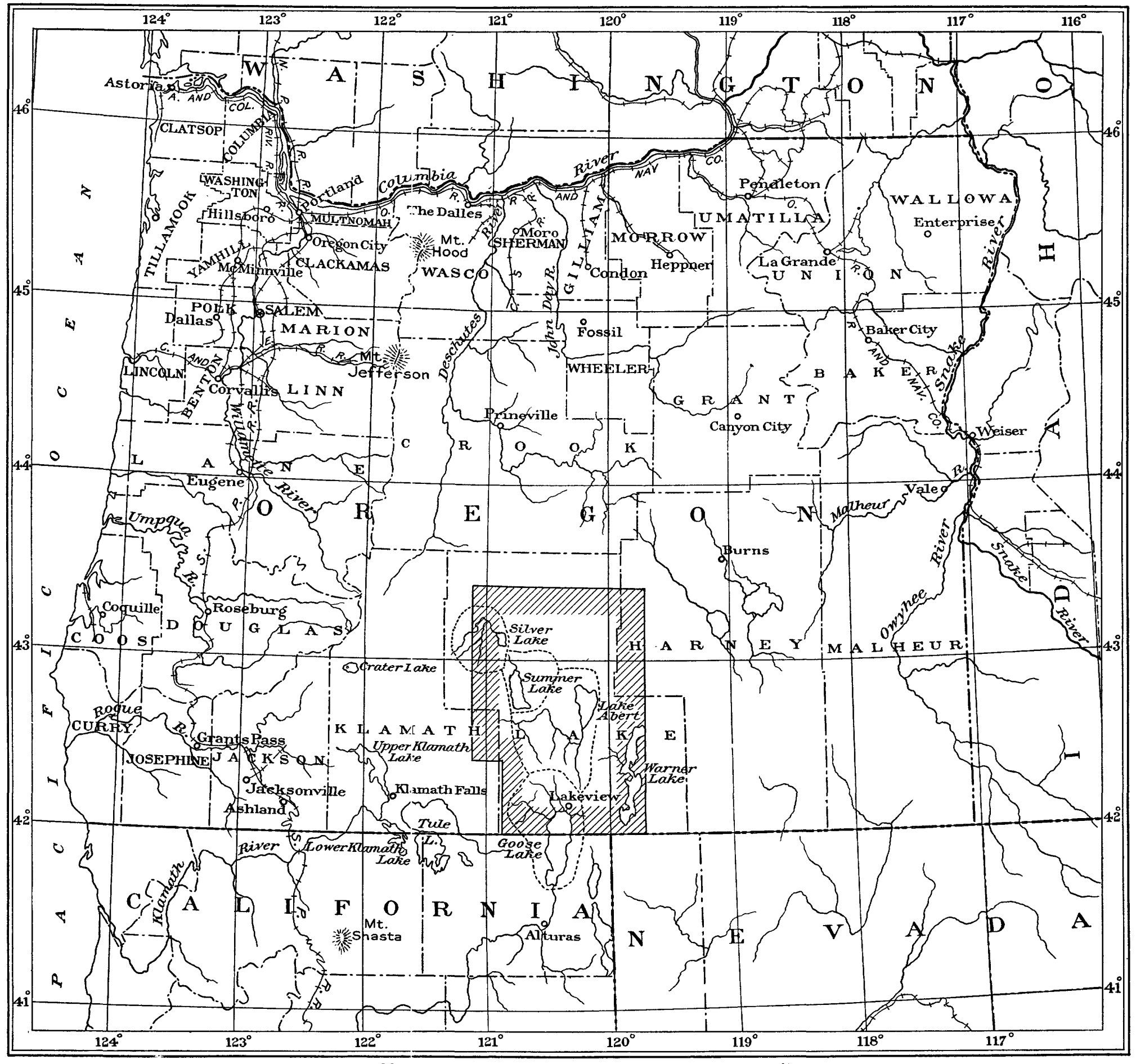

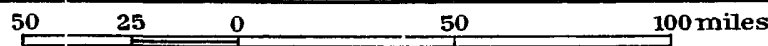





\title{
GEOLOGY AND WATER RESOURCES OF A PORTION OF SOUTH-CENTRAL OREGON.
}

\author{
By Gerald A. Waring.
}

\section{INTRODUCTION.}

\section{OBJECTS OF RECONNAISSANCE.}

The rapidly increasing settlement and development of the West which has accompanied the recent industrial expansion of the United States has led to a growth of interest in all of those factors that affect its adaptability to human needs. One of the clearest evidences of this increasing interest is the constant demand for definite and trustworthy information concerning its climate, soils, mineral resources, timber, and water. So great is this demand that the Federal and local bodies which have been organized to study the natural resources are scarcely able to meet it.

In the arid and semiarid sections no question is of more vital importance than that of water supply. Where water can be introduced or developed in abundance colonization will take place; where water exists in limited quantity, sparse settlement is possible; but where water is not to be had present conditions must continue. The water-resources branch of the United States Geological Survey has for many years been making systematic studies of water supplies, both surface and subsurface, and in connection with work under way in many localities, both in the East and in the West, in the fall of 1906 the writer was assigned to carry out a reconnaissance in southcentral Oregon.

\section{AREA EXAMINED.}

The area examined lies mostly within and includes the greater part of Lake County, so that in the following pages it will often be referred to simply as Lake County. Its location and extent are shown on the index map, Pl. I.

The field work was done, except along the main roads, almost entirely on horseback, for nearly all of the country except the steeper 
mountain slopes may be thus traversed. Since much of it is sparsely settled, a light buckboard, on which food, blankets, and horse feed could be carried, was used wherever practicable along the rather widely separated roads.

As no map showing the relief with any approach to accuracy existed, the accompanying topographic map (PI. II) has been prepared; it is based on field observations with pocket compass and aneroid barometer and on data compiled from all other available sources. Samples of soil and water were also collected for analysis, and rock specimens were gathered for future study. The following report on this region therefore includes a discussion of its present water resources and the development of a greater supply, a statement of its agricultural possibilities, and a summary of the data collected concerning its geology.

\section{ACKNOWLEDGMENTS.}

In collecting these data the writer gained much information from the residents of the county, to whom acknowledgment is here made for aid rendered in various ways, both during and since the time spent in the region. Thanks are due especially to Mr. F. P. Light, of Lakeview; Mr. Virgil Conn, of Paisley, and Mr. F. M. Chrisman, of Silver Lake.

\section{PREVIOUS STUDY.}

This region has been little studied by geologists or other scientists, partly because, being remote from railroads, it is difficult of access, but mainly, perhaps, because of the monotony of its natural features and its sparse settlement. In 1882 Prof. I. C. Russell made a hasty trip through the region, his observations being embodied in the Fourth Annual Report of the United States Geological Survey. ${ }^{a}$ The late Thomas Condon, professor of geology in the University of Oregon, crossed Christmas Lake Valley, and Prof. Edward D. Cope also visited the region and published some results of his studies on its fishes and fossils. ${ }^{b}$ Mr. J. O. Snyder, professor of zoology at Stanford University, has been studying the fishes of its lakes and streams, and the results of his investigations will appear soon in a bulletin of the Bureau of Fisheries; but with the exception of the papers of Professors Russell and Cope, little has been published treating especially of this area. Professor Russell probably visited and studied a greater extent of this northwestern country than any other scientific observer, and many references to his various publications will be made in this paper.

\footnotetext{
a Russell, I. C., A geological reconnaissance in southern Oregon: Fourth Ann. Rept. U. S. Geol. Survey, 1884, pp. 431-464.

$b$ Cope, E. D., The Silver Lake of Oregon, and its region: Am. Naturalist, November, 1889, pp. 970-982; On the fishes of the Recent and Pliocene lakes of the western part of the Great Basin and of the Idaho Pliocene lake: Proc. Philadelphia Acad. Sei., vol. 35, 1884, pp. 134-167.
} 


\section{GEOGRAPHY.}

\section{GENERAL FEATURES.}

Central and southeastern Oregon lies in the northern end of that great area between the Rocky Mountains and the Sierra Nevada from which no streams discharge into the ocean, and which on this account is known as the Great Basin region of interior drainage.

Lake County is in the northwestern extension of this Great Basin region. To the north, beyond the Pauline Mountains, is the John Day River basin, and to the northwest, beyond the Walker Mountains and other eastern outliers of the Cascade Range, is the valley of Deschutes River; while the Summer Lake "rim rock," known as Winter Ridge, and its mountainous southward extension separate the area herein considered from the Klamath Lake drainage area.

Although this southwestern portion of the county is mountainous, the surface of the northern part and of the region to the east is that of a broken plateau, whose mean elevation above sea level is between 4,500 and 5,000 feet. Over this uneven surface the many depressions either contain shallow lakes or are sinks in which temporary ponds exist only during the wet season. In this plateau region there are no rivers, and even well-defined stream channels are rare.

\section{TOPOGRAPHY.}

\section{MOUNTAINS.}

The area just referred to, in the southwestern part of the county, is cut into more mountainous relief by the branches of Chewaucan and Sprague rivers, giving it a very different kind of topography from that of the rest of the area considered, in which absence of the type of relief produced by stream erosion is a chief characteristic. On the southeastern border of the Chewaucan River drainage basin an elevation of more than 7,000 feet is reached at several points, while other, more isolated masses, such as Crooks Peak, rise to heights of more than 6,500 feet. The steep mountain slopes back of Lakeview also rise fully 2,000 feet above the valley, and contain two or three summits well above the 7,000-foot contour.

\section{SCARPS.}

Although the northern and eastern part of the area studied has the character of a broken plateau, one may travel in some directions for many miles in the level sandy lake valleys or over the approximately level rocky "high desert" without crossing more than an occasional depression. But the chief features that relieve the monotony of the region are the great scarps that have given it the broken character. These trend generally north and south, and the 
four principal lines border the principal lake valleys, or undrained basins. Along its entire eastern side Warner Valley is thus bounded by a great escarpment, rising to a height of approximately 3,000 feet above the valley floor, while on its western side a lower but also very abrupt scarp limits this valley. Another very prominent line of bluffs marks the eastern edges of the basins of Goose, Abert, and Alkali lakes. Steep but comparatively smooth and rounded slopes mark this escarpment where it forms the western face of the hills above Lakeview and overlooking Goose Lake, but along the edge of Abert Lake it forms a very striking cliff that rises from the water's edge to a height of fully 2,000 feet, the upper 600 feet being nearly perpendicular. The hills north of Lake Abert obscure this feature for a few miles, but along the Alkali Lake basin there is again an abrupt scarp, 1,200 feet in height, which is lower to the north and dies out near the base of Wagontire Mountain. Another scarp, which forms a low bluff near the south end of Lake Abert, extends along the northeast side of Chewaucan Marsh, attains a height of about 1,300 feet opposite Paisley, and passes into the broken country beyond. Although on the western side of this marsh also the hills rise steeply, it is along Summer Lake that the fourth prominent scarp line is best developed, in the ridge named by Frémont "Winter Ridge." Silver Lake is confined on each side by scarps which at its southern end reach 400 feet in height, but these are only a few miles in extent, and are by no means as conspicuous as the others described.

\section{MINOR FEATURES.}

The surface of the rocky plateau area lying between Christmas Lake and Alkali Lake valleys, known as the "high desert," has a minor relief peculiar to itself. Instead of well-defined stream channels, it has a series of long depressions, approximately parallel, trending in a general way from north to south. The larger of these resemble on a small scale the coulées of Washington, described by Calkins; ${ }^{a}$ they are often limited by nearly vertical walls of basalt approximately 50 feet in height. The bottoms of these depressions are so nearly horizontal as to make it in some instances impossible to tell with the eye alone the direction of the slope. In them a string of sinks or small playas takes the place of a drainage channel. One of these sinks, near the road between Alkali Lake and Paisley, is shown in Pl. III, $A$. In the spring they may contain a few inches of water, but during the greater part of the year they are dry.

As for other minor features in the northern part of the county, mention may be made of the several mountain masses and peaks

$a$ Calkins Frank C., Geology and water resources of a portion of east-central Washington: WaterSupply Paper No. 118, U. S. Geol. Survey, 1905, p. 42. 


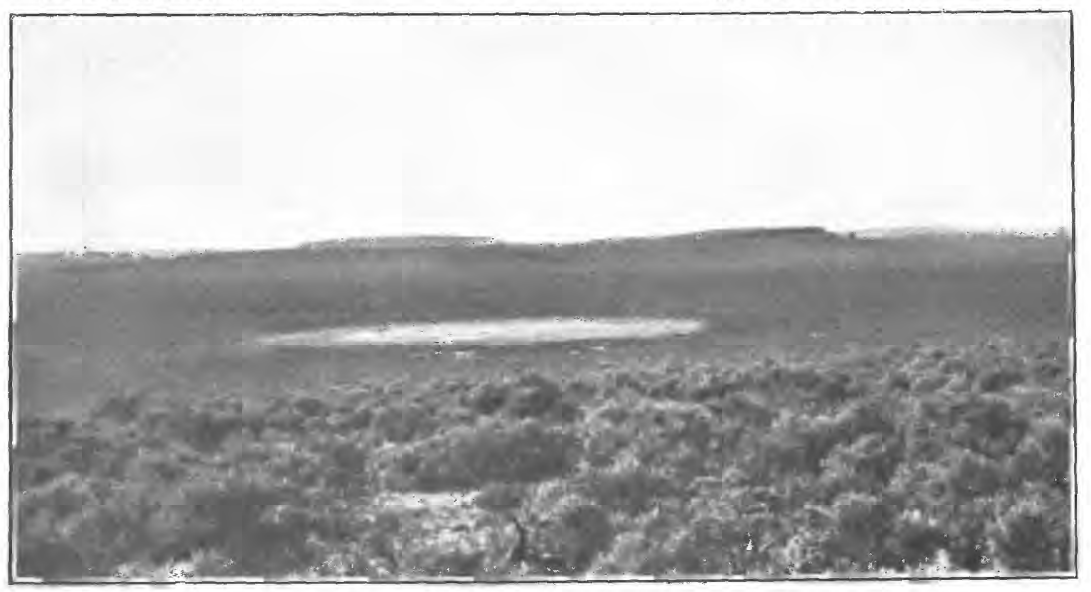

A. TYPICAL SINK IN HIGH DESERT NEAR ALKALI LAKE.

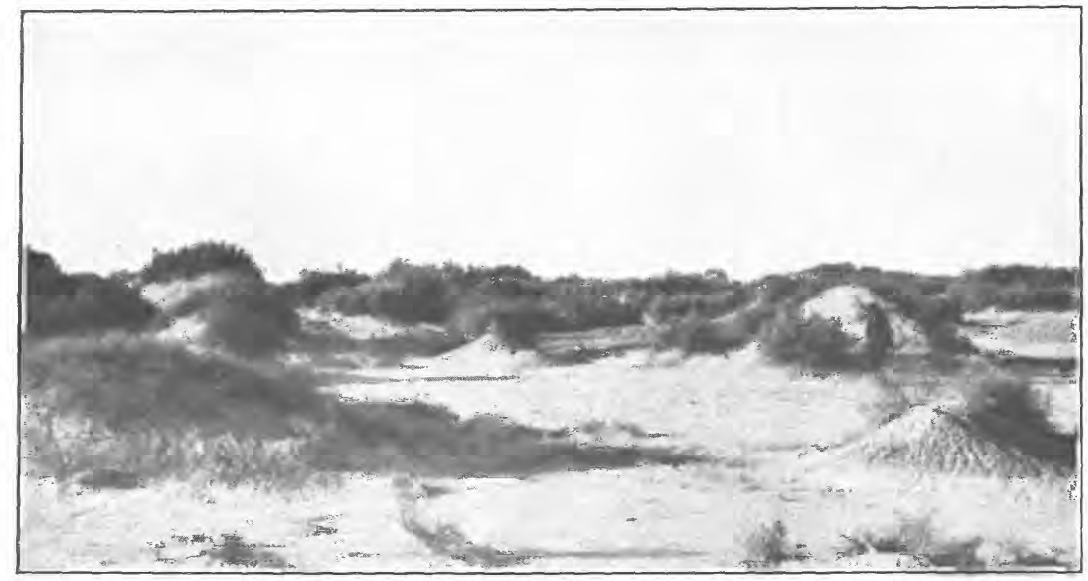

B. HILLOCKS NEAR ALKALI LAKE.

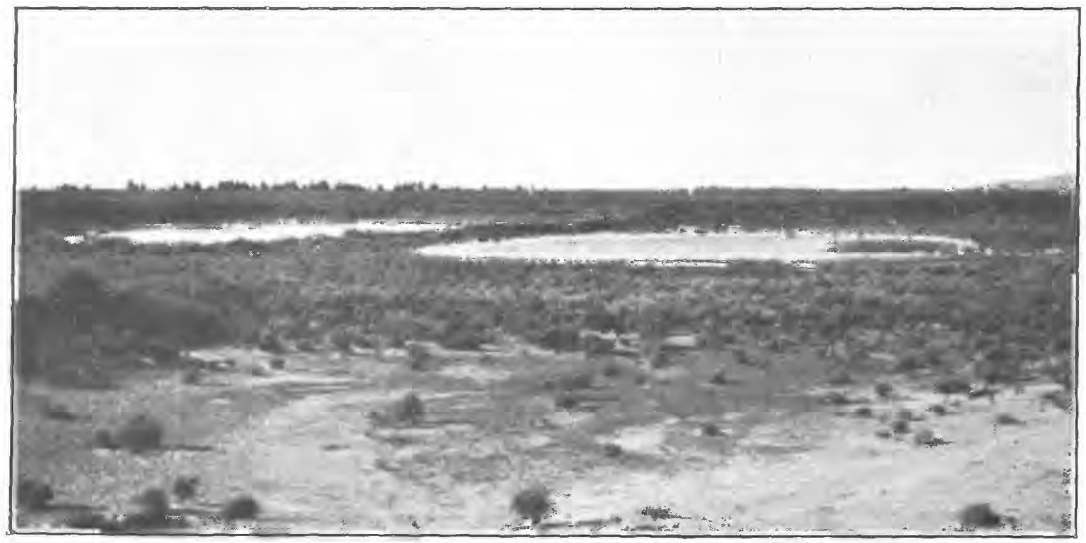

C. ALKALINE POOLS IN CHRISTMAS LAKE VALLEY. 

that rise above the common level, such as Wagontire and Juniper mountains, and the smaller, isolated mesas and buttes.

In this part of the county, just north of Christmas Lake Valley, there is an area covered with lava and cinder cones representing a very recent period of volcanic activity. Many of these cones or extinct volcanoes are very perfect funnel-shaped craters, and rise directly from the nearly level, though in detail harsh and jagged, surfaces of the lava flows.

The sand dunes near Fossil Lake, in Christmas Lake Valley, illustrate still another topographic type. Extending eastward from this lake, which is only a few acres in extent, is a region of sand hills, fully 6 miles long and averaging perhaps 2 miles in width. The prevailing west wind has heaped the sand into great dunes with steep eastern faces and gentle westward slope. These are slowly traveling eastward and have encroached nearly 3 miles on the part of the "high desert" known as Pine Ridge.

The lower slopes along the western side of Summer Lake are examples of typical landslide topography, and were noted by Russell in 1882. Their principal features are the small basins between the back of the slide and the cliff from which the mass has been loosened, in which water sometimes collects, and the great blocks of tuffaceous material in the landslide débris, whose bedding planes dip in various directions.

Another similar landslide area is that at the southern end of Lake Abert, at the base of the escarpment. It is illustrated in Pl. IV.

Still another minor but interesting feature is to be seen typically developed in the flat near Alkali Lake. Conical hillocks, in many cases 10 feet high, somewhat resembling great haycocks (Pl. III, B), and usually topped by greasewood, are thickly clustered on the level surface. Along the borders of the flat these are worn down and rounded off into the more usual "hogwallow" type of mound.

These minor features help much to relieve the monotony of the surface, and, as they are on this account very noticeable, have been thought worthy of brief mention; but the three most significant general features in the topography of this region, and the ones that should be borne in mind in considering the land forms are (1) the great persistent scarps that extend from north to south, (2) the undrained basins at the bases of these scarps, usually occupied by lakes or playas, and (3) the general lack of well-defined drainage over a large part of the surface.

\section{LAKES.}

The county has been well named, for besides the larger lakes, Silver, Summer, and Abert, approximately 15, 70, and 60 square miles in area respectively, the Warner Valley chain of lakes and the northern part of Goose Lake lie within the county. Thorn, Christmas, and 
Fossil lakes are small water bodies in Christmas Lake Valley, and there are also several large marshes and numerous playas or intermittent lakes. But these numerous water bodies must not be taken to indicate an abundance of water in the region, for it will be remembered that none escapes through surface streams, and that the lakes are only the collecting basins for the run-off from the mountain slopes or the flow from the springs. In a well-watered area with the topographic peculiarities of Lake County the water bodies would be much more numerous and much larger than those that exist there.

\section{CHARACTER OF THE LAKES.}

All of the lakes are shallow. None are known to exceed 25 feet in depth, although there is an unconfirmed report of greater depths in the eastern side of Lake Abert. Christmas and Fossil lakes are only 2 or 3 feet deep, while Alkali Lake is really a playa, since during the summer and fall months it is only an alkaline flat containing two or three briny pools.

The size of these shallow water bodies is dependent on the seasonal rainfall, as, indeed, is their very existence. Since the settlement of the country several important changes in their outlines have taken place. During the earlier emigrant days the trail crossed Goose Lake Valley farther south than at present, the place now being under several feet of water. In the early days of Lakeview (now about 6 miles from the lake) the name of the town was not a misnomer, for the lake then extended much farther north than at present, and in 1869 it overflowed for a short time southward into Pit River. In 1881 also it is said to have overflowed for two hours during a severe gale from the north. ${ }^{a}$ Warner Lake has shrunk during the last half century. The present litigation over lands in its valley hinges on the question whether between 4,000 and 5,000 acres, now dry, was swamp land or part of the bed of the lake at the time of the passage of the swamp land act in 1860 . Although before his reconnaissance in 1882 Silver Lake was not known to have gone dry, Russell inferred from its comparative freshness that it must have done so within recent years, since lakes having no outlet are believed to be freshened by desiccation. Therefore the fact that after the exceptionally dry season of 1887-88 the lake did dry up, its bed was taken up for farms, and one season's crops were gathered before the lake again filled, is of especial interest.

ALKALINITY.

Like all lakes having no outlet, those of the area under discussion are alkaline, the waters of Summer and Abert lakes being exception-

a Russell, I. C., A geological reconnaissance in southern Oregon: Fourth Ann. Rept. U. S. Geol. Survey, 1884, pp. 456-457. 


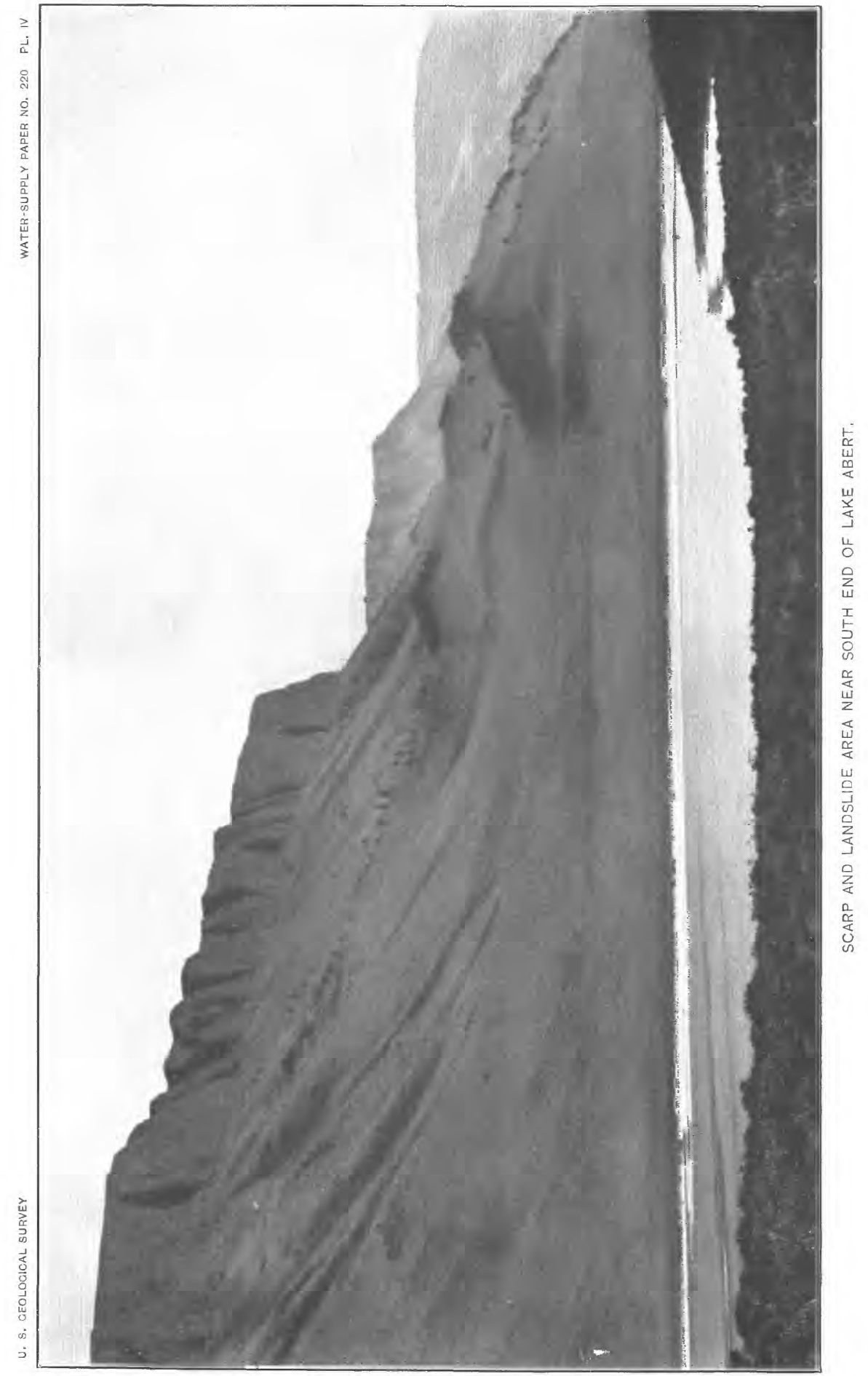



ally so. Russell, in his reconnaissance report, ${ }^{a}$ gives an analysis of water from Lake Abert, by F. W. Taylor, and remarks that the percentage of potassium salts is greater than in any other lake whose composition is known. But the following analysis of water from this lake is given by T. M. Chatard, ${ }^{b}$ who says:

The sample was collected by H. T. Biddle at the middle of the west side of the lake, 1 foot below the surface, 30 to 40 feet from shore, September, 1887. *** This analysis shows, as would be expected, that the water of Abert Lake does not differ materially from that of any other alkali lake so far discovered. Its low percentage of sulphate is its greatest merit [for soda extraction] since it is of all impurities the most difficult to remove and the most deleterious when present.

\section{Analysis of water of Lake Abert.a}

[Average of two samples. T. M. Chatard, analyst.]

\begin{tabular}{|c|c|c|}
\hline & $\begin{array}{c}\text { Grams per } \\
\text { liter. }\end{array}$ & Per cent. \\
\hline 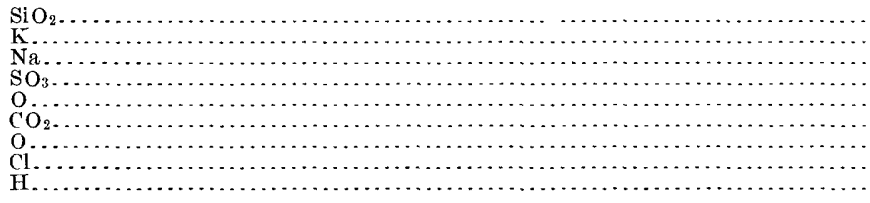 & $\begin{array}{r}0.232 \\
.538 \\
14.690 \\
.588 \\
.118 \\
7.024 \\
2.462 \\
13.462 \\
.058\end{array}$ & $\begin{array}{r}0.59 \\
1.37 \\
37.51 \\
1.50 \\
.30 \\
17.93 \\
6.28 \\
34.67 \\
.15\end{array}$ \\
\hline \multirow{3}{*}{ 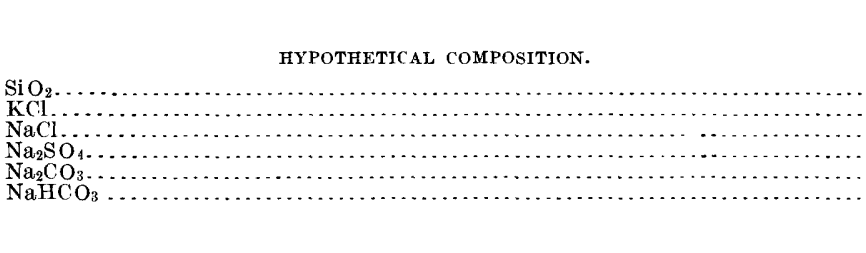 } & 39.172 & 100.00 \\
\hline & $\begin{array}{r}.232 \\
1.027 \\
21.380 \\
1.050 \\
10.611 \\
4.872\end{array}$ & $\begin{array}{r}.59 \\
2.62 \\
54.58 \\
2.68 \\
27.09 \\
12.44\end{array}$ \\
\hline & 39.172 & 100.00 \\
\hline
\end{tabular}

$a$ Chatard says of this analysis (in Am. Jour. Sci., 3d. ser., vol. 136, 1888, pp. 146-150): "The total quantity at my disposal was about $200 \mathrm{c}$. c., an amount too small for any extended research, but sufficient for all practical purposes. For each determination 25 c. c. $(=25.7792$ grams $)$ were taken. Specific gravity, 1.03117 at $19.8^{\circ}$."

This analysis, giving a content of about 3.9 per cent of salts, shows the water to be more strongly impregnated than ocean water, which contains about $3 \frac{1}{2}$ per cent of mineral salts.

No analysis of the water of Summer Lake is at hand, but a test at its western edge, with the electrolytic bridge, ${ }^{c}$ indicates a content

a Op. cit., p. 454.

$b$ Chatard, T. M., Natural soda, its occurrence and utilization: Bull. U. S. Geol. Survey No. 60, 1890, pp. 50-52.

$c$ The alkaline salts of natural waters are electrolytes, and the more alkaline a water is the less resistance it offers to the passage of an electric current. Hence by means of an electrolytic Hridge, consisting essentially of an electric battery, resistance coils, and a suitable cup to hold the water to be tested, the resistance offered to the passage of the current can be measured, and by comparison of this with the resistance measurements of other waters of which analyses also are available the amount of salts in solution can be roughly determined. Waters containing only 8 or 10 parts of salts in 100,000 are exceptionally pure, and those containing 30 parts in 100,000 are considered very good. The limit for domestic or irrigation purposes is about 400 parts in 100,000 , although it depends largely on the character of the salt content.

The average alkaline content of the fresh Iakes of North America is given by Russell (Lakes of North America, p. 55), as between 15 and 18 parts in 100,000 . 
near the shore of 500 or more parts of salts in 100,000. A sample of the efflorescent alkali from its eastern shore consisted almost wholly of the sulphate of soda (Glauber's salt), carbonate of soda (sal soda), and bicarbonate of soda (baking soda).

Similar tests of the waters of Silver and Thorn lakes indicated only about half as great a salt content as the water of Summer Lake. At its northern end Christmas Lake is very alkaline, but at its southern end, where the water is of much better quality, it is fed by an intermittent spring. The efflorescence here, as at Summer Lake, consists of the carbonates and sulphate of soda.

\section{CLIMATE.}

GENERAL CONDITIONS.

The climate of eastern Oregon is very different from that of the better known western valleys of Willamette and Columbia rivers, for east of the Cascade Range precipitation is scanty and the region is largely desert in character. The climate is not severe, however. Its temperature has been compared to that of Ohio or Illinois, although its precipitation is much less. The summer days are warm, often excessively so on the rocky plateaus, but the nights are cool, and in some parts of the country frost may be expected in any month of the year. The stormy season is late, February, March, and April often being the most disagreeable months, while open weather sometimes lasts in the fall until Christmas time. On the higher mountains and plateaus snow may lie all winter, but in many of the valleys it melts after each storm.

Weather records have been kept in only two places in Lake County for any length of time-at Lakeview and at Silver Lake. A station was established at Paisley two years ago, and it is hoped that records will also soon be kept at Cliff, near Fossil Lake. In a late bulletin of the Department of Agriculture ${ }^{a}$ the following statements, especially applicable to Lake County, are made in an article on the climate of Oregon by Edward A. Beals. He says that the seasonal precipitation is chiefly between the months of October and March, with a secondary maximum during May and June, followed by a relatively dry summer. The prevailing winds are southerly in winter and from the northwest in summer, southerly winds being at all times the rain bringers, and in summer causing the lowest temperature. The hot winds are from the northeast in summer, while in winter the cold winds are from this quarter. Thunderstorms occur in spring and early summer, but rarely during the winter months.

$a$ Henry, A. J., Climatology of the United States: Bull. Q, U. S. Dept. of Agriculture, 1906, pp. 498-499. 


\section{TEMPERATURE AND RAINFALL RECORDS.}

In the tables following are compiled the data obtainable on temperature and precipitation in this region:

Average temperatures and precipitation at Silver Lake and Lakeview, Oreg. a

\begin{tabular}{|c|c|c|c|c|}
\hline \multirow[b]{2}{*}{ Month. } & \multicolumn{2}{|c|}{$\begin{array}{l}\text { Silver Lake (elevation, } \\
4,300 \text { feet). }\end{array}$} & \multicolumn{2}{|c|}{$\begin{array}{c}\text { Lakeview (elevation, } \\
5,000 \text { feet). }\end{array}$} \\
\hline & $\begin{array}{l}\text { Mean tem- } \\
\text { perature } \\
\text { in }{ }^{\circ} \mathrm{F} .\end{array}$ & $\begin{array}{l}\text { Mean pre- } \\
\text { cipitation } \\
\text { in inches. }\end{array}$ & $\begin{array}{l}\text { Mean tem- } \\
\text { perature } \\
\text { in }^{\circ} \mathrm{F} .\end{array}$ & $\begin{array}{l}\text { Mean pre- } \\
\text { cipitation } \\
\text { in inches. }\end{array}$ \\
\hline 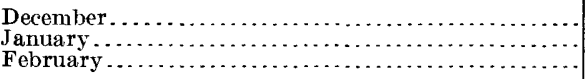 & $\begin{array}{l}30 \\
29 \\
30\end{array}$ & $\begin{array}{r}1.2 \\
.8 \\
1.0\end{array}$ & $\begin{array}{l}30 \\
28 \\
29\end{array}$ & $\begin{array}{l}2.2 \\
2.4 \\
2.2\end{array}$ \\
\hline Winter ................ & 30 & 3.0 & 29 & 6.8 \\
\hline 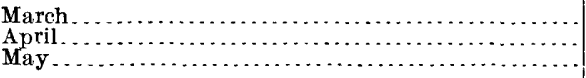 & $\begin{array}{l}36 \\
43 \\
50\end{array}$ & $\begin{array}{r}1.0 \\
.9 \\
1.2\end{array}$ & $\begin{array}{l}36 \\
43 \\
51\end{array}$ & $\begin{array}{l}1.7 \\
1.4 \\
1.7\end{array}$ \\
\hline Spring........ & 43 & 3.1 & 43 & 4.8 \\
\hline 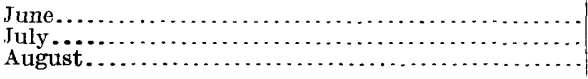 & $\begin{array}{l}56 \\
62 \\
62\end{array}$ & $\begin{array}{l}.8 \\
.6 \\
.2\end{array}$ & $\begin{array}{l}58 \\
66 \\
66\end{array}$ & $\begin{array}{r}1.2 \\
.3 \\
.3\end{array}$ \\
\hline Summer. . . . . . . . . . . . . . . . . . . . & 60 & 1.6 & 63 & 1.8 \\
\hline 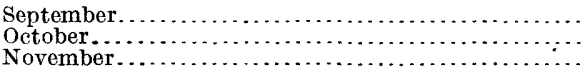 & $\begin{array}{l}53 \\
45 \\
36\end{array}$ & $\begin{array}{l}.5 \\
1.1 \\
1.1\end{array}$ & $\begin{array}{l}57 \\
49 \\
38\end{array}$ & $\begin{array}{r}.7 \\
.9 \\
2.0\end{array}$ \\
\hline Fall $\ldots . . . \ldots \ldots \ldots . . . . .$. & 45 & 2.7 & 48 & 3.6 \\
\hline ' Annual........... & 44 & $\begin{array}{r}10.4 \\
10.06\end{array}$ & 46 & $\begin{array}{l}17.0 \\
16.73\end{array}$ \\
\hline $\begin{array}{l}\text { Mean maximum } \ldots \ldots \ldots \ldots \\
\text { Mean minimum } \ldots \ldots \ldots \ldots\end{array}$ & $\begin{array}{l}61 \\
28\end{array}$ & & $\begin{array}{l}60 \\
32\end{array}$ & \\
\hline $\begin{array}{l}\text { Absolute maximum..... } \\
\text { Absolute minimum...... }\end{array}$ & $\left\{\begin{array}{r}104 \\
\text { July, } 1891 \\
-32 \\
\text { Nov., } 1896\end{array}\right.$ & & $\left\{\begin{array}{lr} & 102 \\
\text { July, } & 1896 \\
1 & -24 \\
\text { Jan., } & 1888\end{array}\right.$ & 1 \\
\hline
\end{tabular}

a From Bull. Q, U. S. Dept. Agr., 1906, pp. 966, 969.

$b$ From First Bienn. Rept., Oregon State Engineer, 1905-6, Pl. I.

Rainfall record at Siler Lake, Oreg. ${ }^{a}$

\begin{tabular}{|c|c|c|c|c|c|c|c|c|c|c|c|c|c|}
\hline Year. & $J$ an. & Feb. & Mar. & Apr. & May. & June. & July & Aug. & Sept. & Oct. & Nov. & Dec. & Annual. \\
\hline 889 & & & & & & & & & & & 1.48 & 1.31 & \\
\hline & 1.03 & 2.74 & 1.04 & 0.34 & & & & & & & & Tr. & \\
\hline 189 & .62 & 3.08 & .77 & 1.46 & 2.65 & 2.24 & 1.63 & & & $\cdots$ & 1.50 & 1.46 & \\
\hline 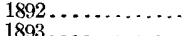 & .12 & .91 & 2.40 & .77 & 2.52 & & $\cdots$ & & & & & & \\
\hline . & 1.50 & .75 & 1.09 & .93 & $\cdots$ & .82 & & & & & & & \\
\hline & & $\cdots$ & & 1.89 & .64 & .30 & .13 & 0.39 & 0.18 & 0.49 & 2.32 & & \\
\hline & & & & & & & & & & & & & \\
\hline 1898. & .27 & .30 & .0 & $\begin{array}{l}.25 \\
.22\end{array}$ & $\begin{array}{l}1.91 \\
1.87\end{array}$ & $\begin{array}{r}2.65 \\
.76\end{array}$ & $\begin{array}{l}.07 \\
.20\end{array}$ & .00 & $\begin{array}{l}.39 \\
.20\end{array}$ & $\begin{array}{l}.23 \\
.56\end{array}$ & $\begin{array}{r}.13 \\
2.03\end{array}$ & $\begin{array}{r}1.47 \\
.38\end{array}$ & 6.9 \\
\hline & 1.40 & .24 & 2.57 & 1.02 & .49 & Tr. & .00 & .4 & .37 & 1.44 & .75 & 1.68 & 10.36 \\
\hline 1900 & .80 & $\mathrm{Tr}$. & .31 & .53 & .90 & .42 & Tr. & .45 & .49 & 2.0 & .40 & .95 & 7.34 \\
\hline & .08 & 1.69 & .30 & .10 & .34 & .04 & & $\cdots$ & 1.09 & 1.31 & .57 & & \\
\hline 22. & .24 & 1.45 & .25 & 2.27 & .67 & Tr. & & & & & & 2.16 & \\
\hline 903. & 1.73 & .55 & 1.15 & & .52 & .72 & & & & & & & \\
\hline$\because$ & & & & .98 & .65 & .54 & 1.60 & .00 & & .56 & .55 & & \\
\hline $\begin{array}{l}1905 \\
1906\end{array}$ & & & 1.03 & $\begin{array}{r}70 \\
38\end{array}$ & $\begin{array}{l}1.48 \\
2.18\end{array}$ & 2.33 & .05 & $\begin{array}{r}.00 \\
78\end{array}$ & 1.34 & .55 & .23 & .07 & $\begin{array}{r}\text { (?) } 7.78 \\
11.58\end{array}$ \\
\hline 1900 & 1.98 & .55 & 1.89 & .38 & 2.18 & 1.08 & .04 & .88 & $\cdots$ & $\cdots$ & . 42 & 1.00 & 1.000 \\
\hline
\end{tabular}

a Station established by Signal Service October.1889. No instrument shelter used for first few years Temperature record therefore considered somewhat unreliable, but rainfall thought to be good. 
Rainfall record at Lakeview, Oreg. ${ }^{a}$

\begin{tabular}{|c|c|c|c|c|c|c|c|c|c|c|c|c|c|}
\hline Year & Jan. & Feb. & Mar. & Apr. & May. & June. & July. & Aug. & Sept. & Oct. & Nov. & Dec. & Annual. \\
\hline 90 & & & & & & 0.23 & 0.00 & $\mathrm{Tr}$. & 2.29 & 0.12 & $\mathrm{Tr}$. & 1.00 & \\
\hline & 0.49 & 4.95 & 2.06 & 1.09 & 3.09 & 2.97 & .90 & 0.15 & .38 & .42 & 1.07 & 6.38 & 24.55 \\
\hline & 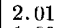 & 1.57 & 1.27 & 2.15 & 2.04 & .67 & .08 & Tr. & 1.51 & 1.99 & 3.78 & 2.47 & 19.57 \\
\hline & 1.89 & 2.97 & 1.74 & 2.44 & & .07 & .31 & .00 & 1.19 & 1.59 & 3.68 & 1.65 & 17. \\
\hline & 4.66 & 4.92 & 3.18 & .58 & 2.24 & & & & & & .97 & 3.45 & \\
\hline & 5.15 & 1.02 & 2.0 & .52 & 1.33 & Tr. & .20 & .45 & .60 & Tr. & 1.16 & 2.25 & 14 \\
\hline & 3.55 & 1.00 & 2.32 & 3.94 & 2.21 & .10 & .50 & .51 & 1.17 & .60 & 2.96 & 1.45 & \\
\hline 189 & 1.13 & 2.95 & 3.13 & 1.03 & .92 & 2.09 & .10 & .10 & .86 & .36 & 1.78 & 1.68 & 16.13 \\
\hline & 1.40 & 1.08 & .10 & $x^{\circ}$ & 1.74 & .24 & .08 & & Tr. & .95 & 1.25 & 1.50 & \\
\hline & & .80 & 2.25 & 1.18 & 1.10 & .20 & Tr. & .50 & .00 & 2.60 & 2.15 & 2.43 & \\
\hline & 1.44 & 1. & 1.04 & 1.38 & & & & & & & & 1.03 & \\
\hline & 3.01 & 2.58 & .59 & 1.07 & .60 & Tr. & .0 & .27 & 1.09 & 1.2 & 1.73 & 2.78 & 15.10 \\
\hline & & 3.32 & 1.41 & 2.28 & 2.22 & .10 & .4 & .1 & .21 & 1.17 & 2.20 & 2.38 & \\
\hline & 3.59 & 1.14 & 1.93 & .48 & .53 & 1.23 & .4 & .3 & .06 & .44 & 4.94 & .99 & 16.11 \\
\hline & 1. & 5. & 4.53 & 2.76 & .27 & .59 & .4 & .0 & 1.10 & 1.43 & .20 & 3.27 & 21.47 \\
\hline & 1.67 & .73 & 2.47 & .44 & 1.41 & .70 & .0 & .07 & .50 & .22 & .63 & 1.08 & 9.92 \\
\hline 1906 & 4.63 & 1.59 & 3.14 & .53 & 1.88 & 1.21 & .20 & .00 & .82 & 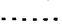 & 1.52 & 3.72 & 19.24 \\
\hline
\end{tabular}

a Station established by Signal Service January 1, 1884; discontinued October 13, 1888. Reestablished as voluntary station by Signal Service June 1, 1890.

These records, besides showing the much greater precipitation at the southern station, indicate that at Lakeview the climate is also slightly warmer. Although the mean maxima and minima of temperature do not indicate as great extremes in the southern part, the mean seasonal temperatures show that there really is a greater average difference between summer and winter at Lakeview than in the more open Silver Lake region. The difference in these records is probably due more to the difference in elevation of the two observing stations, than to any other single factor. The station at Lakeview is at about 5,000 feet elevation, or 700 feet higher than that at Silver Lake. The former place is also at the base of a range of steep mountains, while the latter is in the open valley.

\section{VEGETATION.}

There are few absolutely barren areas in southern Oregon, such as are found in northwestern Nevada and in the Mohave and Colorado deserts. Nearly all of the country produces some sort of natural growth, though in no place is this so dense as to interfere seriously with travel on horseback or on foot. The mountains are rather openly forested with several varieties of pine and fir and. with a scattering undergrowth of manzanita, buckthorn, and mountain mahogany. The lack of dense underbrush has no doubt in large measure protected these forests from fires such as yearly burn along the western slopes of the Cascades. The rocky plateaus support a scanty growth of sage and are in some places dotted with junipers, which seem to grow best on the most rocky areas. The growth of pine trees at Pine Ridge, on the eastern side of Christmas Lake Valley, among the dead trunks of junipers, is a unique occurrence in this region, and seems closely related to the soil conditions and moisture as affected by the drifting sands from the valley. 
In the sandy alluvial soil of the lake valleys the sage often grows to large size. Three species of rayless goldenrod are also found, chiefly in the valleys and on the borders of playas. On the more alkaline flats, as at Christmas Lake and Alkali Lake, the greasewood seems to thrive best, its young shoots being one of the earliest sources of forage for stock in the spring.

Over nearly all of this area, both in the mountains and on the plateaus, bunch grass and rye grass grow in sufficient quantity to furnish range for thousands of head of stock, while from the marshes many tons of wild hay are cut every year for winter feed.

A number of the native plants were incidentally collected during the study of the region, and were afterward kindly identified by Mr. Le Roy Abrams, assistant professor of systematic botany at Stanford University. Among them are a dozen species of grasses and of desert shrubs, the black sage (Artemisia tridentata), common juniper, rayless goldenrod (Bigelovia), greasewood (Sarcobatus), lupine, and milk vetch or loco weed. In the lake valleys, the marsh elder, bush willow, and buckwheat, with other small plants, were found. On the mountain slopes, besides the forest trees of pine and tamarack, are the buckthorn, manzanita, maple, cottonwood, and quaking asp, together with a number of shrubs and plants of the rose family, among which are the mountain mahogany, cherry, strawberry, and wild plum. The wild plum is found in abundance in several localities. The fruit ripens in September, when it is eagerly gathered by both the Indians and the settlers.

The common horehound and alfilerilla, with one or two other California plants, were noticed along the more traveled roads and around sheep corrals, and have probably been introduced from the south by immigrants and flocks of sheep.

ANIMAL LIFE.

In the late seventies the last mountain sheep were seen in this region. Although deer and antelope have been abundant until recent years, the latter rarely came down into the valleys, and the deer also are now seen mostly in the higher country, as the lower lands are being fenced. The gopher, woodchuck, and hedgehog are found especially in the cultivated sections, and the coyote and rabbit in nearly all parts. Around the lakes ducks, geese, and various other kinds of waterfowl abound, while a few sage hens may be occasionally flushed on the plains. But several varieties of chipmunk seem to be the most common form of wild life, both in the timbered areas and on the plains. The scarcity of birds and other small forms of wild life over much of this region is noticeable.

48133 -IRR $220-08-2$ 


\section{SETTLEMENTS.}

Within the county, comprising 7,834 square miles, ${ }^{a}$ with a population close to 3,000 , there are four towns. Lakeview, the county seat (Pl. V), has a population of about 1,000; Paisley, 300; New Pine Creek, 200, and Silver Lake perhaps 100.

Mail and stage lines, operated six times a week, connect Lakeview with New Pine Creek and Madeline (Cal.) to the south, Bly and Klamath Falls to the west, and Paisley, Summer Lake post-office, and Silver Lake to the north. To the east there is service with Plush, Adel, and Warner Lake post-offices three times a week. Egli post-office, just within Harney County, has communication twice a week with Riley and Burns to the northeast. In the newly settled Christmas Lake Valley provisional post-offices have been established at Lake and Cliff, with weekly service to Silver Lake.

The nearest railroads are at Madeline (narrow gage), 95 miles south of Lakeview; Weed (Cal.), and Pokegama (Oreg.), each about 135 miles west of Lakeview; and Shaniko, 166 miles (according to the postroute map) northward from Silver Lake. The latter place indeed claims to be farther from a railroad than any other post-office in the United States. A railway route has recently been surveyed through Christmas Lake Valley, however, and it is hoped that work will soon be begun on the line and that Silver Lake will not hold this unique distinction very much longer.

Except near Lakeview the county roads do not receive much care, and in consequence travel over those least used is slow.

The freight rate between Shaniko and Silver Lake, by teams, is $1 \frac{1}{2}$ cents a pound; so that prices of all heavy or bulky supplies that have to be shipped in, especially grain, flour, and potatoes, are high.

Telephone lines connect the settlements with the railway points, and several cooperative lines connect most of the isolated ranches. Quick communication may thus be had throughout much of the county. In other matters, too, the people are progressive. Lakeview has a water system supplied by springs in the mountains above the town, and both it and New Pine Creek have electric lights, while several buildings in Silver Lake are also furnished with electric light from the plant of Mr. F. M. Chrisman, which uses power generated by a distillate engine.

\section{INDUSTRIES.}

GRAZING.

On account of the presence of natural forage grasses and the unfitness of much of the country for any other purpose stock raising has become the chief industry. Horses and cattle roam in great numbers 


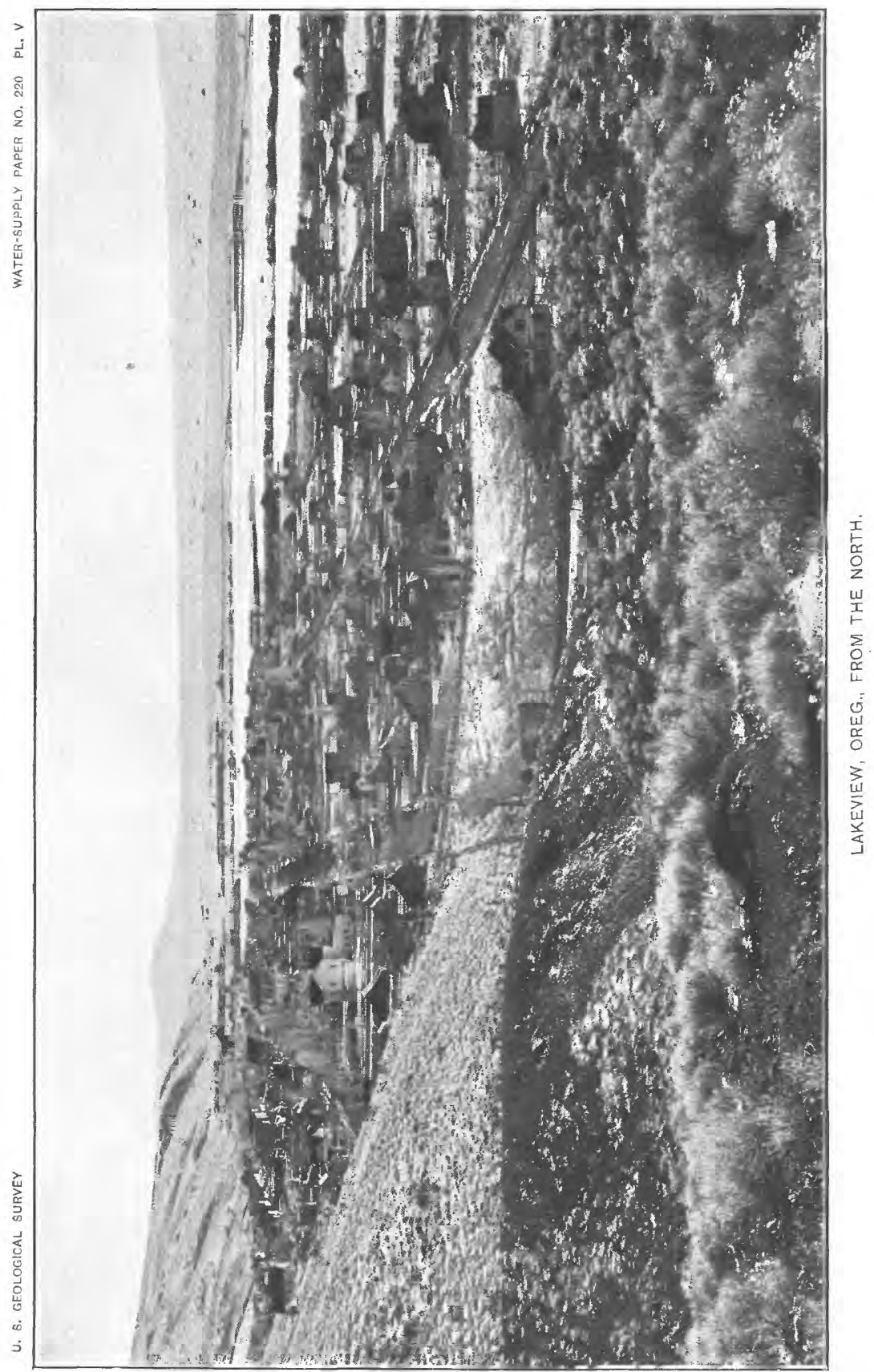



over the plateaus or "high desert," and are owned chiefly by the interests that control the hay ranches of the marsh lands. The scarcity of water in summer limits the range of cattle during that period to the mountains or, on the desert, to the vicinity of water holes. They are usually rounded up for feeding on the marshes during the severe weather of the early spring months. Horses, being able to travel more rapidly, can range farther from water than cattle, and often become so wild that it is almost impossible to collect them for branding or for market. It is said that a band now roams the lava beds in the northern part of the county, and that determined efforts for several years have failed to capture them, because of their wildness and the rough character of the lava surface.

Sheep also constitute an important factor in the county's wealth. During the summer months the flocks are kept in the mountains, where water can be obtained, and are not brought down into the valleys until November or December, when sufficient snow has fallen to furnish water during the winter.

\section{AGRICULTURE.}

Comparatively little farming has yet been done, although most of the fruits and vegetables consumed in the county are raised along the eastern side of Goose Lake and the western shore of Summer Lake. Apples and potatoes are the staples, but the farms near New Pine Creek are also noted for their melons. Nearly all garden vegetables can be obtained during the summer and early fall months, in spite of the fact that frosts are likely to kill the more tender plants. It is the general opinion that more extensive cultivation is lessening the tendency to early frosts, and it is claimed that vegetables, such as tomatoes, can now be grown in several places in the county where formerly they could not.

A number of small dairies, sufficient to supply the local demand for milk and butter, are established in Summer Lake and Goose Lake valleys, but little or none of their products are shipped out.

At Paisley and on the western side of Summer Lake, where water for irrigation is obtained, there are several alfalfa fields, and in these localities a few fields of barley and rye are also grown.

\section{LUMBERING.}

Three or four small sawmills supply the local demand for lumber, the price at the mill being about $\$ 12$ a thousand feet board measure. Yellow pine furnishes nearly all the timber, and also supplies fuel for heating and other purposes, as there is no coal in the region. Gannett ${ }^{*}$ estimates the stand of merchantable timber in Lake County as

a Gannett, Henry, The forests of Oregon: Prof. Paper U. S. Geol. Survey No. 4, 1902, p. 16. 
$3,106,000$ feet board measure, all of which is yellow pine, the average stand to the acre being 3,000 feet.

\section{MINING.}

Near New Pine Creek there has recently been some gold-mining excitement, but in a district a little south of the State boundary. The only prospects worthy of mention within Lake County are those of the Coyote Hills, in what is known as the Lost Cabin gold mining district. This district was brought to the notice of mining men in August, 1906, by the Loftus brothers. The value and extent of the deposits have not yet been proved. Such values as have been found are in oxidized ores in andesitic breccias, a mass of these more acid rocks beneath the basalts that are so generally distributed over Lake County forming the boss exposed in the Coyote Hills.

The alkaline flat at the southeast end of Summer Lake has been located for soda, and a part of Alkali Lake as borax claims, but no development work has been done in either locality.

A small quantity of saltpeter (nitrate of potash) of high quality has been found on the northwestern side of Wagontire Mountain, but the character and extent of the deposit are not known.

\section{HISTORICAL NOTES.}

Some historical notes on the county have been assembled in a "Fistory of Central Oregon," a and the following extracts may not be out of place here:

As early as 1838 a form of government was exercised by the Methodist Missions in "Oregon," and two years later a petition for a civil government was sent to Congress by the people settled on Puget Sound and in the tide-water region of Columbia River. In $1838 \mathrm{Col}$. J. J. Abert prepared a map showing Warner Lake and other natural features of the eastern country, from data procured by trappers and explorers of the Hudson Bay Company, but Col. John C. Frémont seems to have been the first to cross the area now Lake County, and to bring out a clear account of the region. He left The Dalles in November, 1843, on the return trip of his exploring expedition, traveling southward to Klamath Marsh, then eastward across Sycan Marsh. Here the explorers were overtaken by a heavy snowstorm, and when they suddenly came to the edge of the cliff overlooking Summer Lake and saw the valley below green and inviting they bestowed the name of Winter Ridge on the bluff and its present name on the lake at the foot of the bluff. After traveling past Chewaucan Marsh and Lake Abert, which Frémont named after Col. J. J. Abert, chief of the Corps of Topographical Engineers, under whose instructions he was working,

a An illustrated history of Central Oregon, compiled by F. A. Shaver, Arthur P. Rose, and R. F. Steek. Western Hist. Pub. Co., Spokane, Wash., 1905. 
they reached Warner Valley on December 23, and spent Christmas day on the edge of the lake, which they called Christmas Lake. Thence they traveled southward to Pyramid Lake and into California.

Nearly six years later, in 1849, Capt. William H. Warner, United States topographical engineer, explored the country north and east of Goose Lake for an emigrant trail from Sacramento, and was killed by Indians in the valley now bearing his name. It was not until the early sixties that the country was again penetrated by whites, when the discovery of gold in the John Day and Powder River regions led to the establishment of the military post of Fort Klamath along the route of travel from California and Nevada to the new mines. There was also a line of travel between Steins and Warner mountains, leadmg later to the establishment of Fort Warner. So, although without a settler, Lake County was traversed by a number of parties during these years.

In 1868, when as a result of General Crook's campaign the Shoshone Indian war ended, immigration began. In 1872 a weekly mail route was established between Ashland, Oreg., and Lake City, Cal., with a post-office at New Pine Creek. Four years later a post-office was established at Lakeview. In $1874-75$ a post-office was established on the western side of Silver Lake, the town of Silver Lake not being founded until 1886. There were several settlers at Paisley in 1871, and seven years later a store was opened at that place. The county of Lake was formed in 1874. At first it included the present Klamath County, but did not contain Warner Valley, and it did not receive its present boundaries until 1886.

\section{GEOLOGY.}

\section{CHARACTER AND AGE OF ROCKS.}

In studying the geology of the region-the kinds of rocks and their structure - all of the consolidated materials that were seen are volcanic effusives and related volcanic muds, or tuffs. These rocks belong to several lithologic classes and to more than one geologic period, but by far the most extensive series is that of the basaltic flows. These cover nearly all of Lake County and extend eastward beyond Steins Mountain and northward beyond the John Day region, where fossils that have been collected from interbedded sedimentaries determine the age of the flows as Miocene.

No such fossil-bearing beds were found in the Lake County area, and the effusive material was not traced in detail to the place where such beds are exposed. But the material is so similar in lithologic character, in the amount of deformation it has undergone, and in its general relation to the Cascade Range to the west that there is little 
hesitation in placing it in the same general series with the widely extended and well-known Miocene lavas of Washington and northerncentral Oregon. Although these Miocene basaltic lavas cover nearly all of the region examined with the exception of the lake valleys, there are sufficiently large areas of lavas of other types to warrant a preliminary separation into three groups-older acidic effusives, older basaltic effusives, and recent eruptive material. These are tentatively mapped, with their approximate areas, so far as these could be determined in a rapid reconnaissance, on Pl. VI (in pocket).

\section{CLASSES OF ROCKS.}

\section{OLDER ACIDIC EFFUSIVES.}

The rocks of several mountain masses in this region differ enough from the more common basalts, both in the nature of the topography to which they give rise and in their petrologic character, to warrant us in considering them as belonging to an earlier period of more acidic effusion, when the lavas poured out were andesites, rhyolites, and related obsidians. They are perhaps of early Tertiary or preTertiary age. In the succeeding effusions the materials were either basaltic or tuffaceous.

The Coyote Hills and Rabbit Hills masses are placed in the older class because they are composed largely of a light-colored glassy or porphyritic rock that seems to have been disturbed and eroded before being surrounded by the basaltic flows. These lavas are much more acid than the surrounding basalt, and they are regarded tentatively as rhyolites, andesites, and trachytes. In three other places-near Lakeview, near the head of Chewaucan River, and between Silver and Summer lakes-similar rocks were found. Slides of these were examined by E. S. Larsen, jr., and identified as andesite.

Gray Butte, Big Juniper Mountain, and Horning Bend are composed of light-colored rocks that appear also to have been disturbed and eroded before the outpouring of the later basalts. They are rhyolitic in character.

The general form of Wagontire Mountain and its relation to the basalts that dip westward away from it suggest that it also may have been produced by an earlier, possibly local effusion, uplifted since the outpouring of the basalt flood. On its westward side a glassy andesite was found, but the rocks of the eastern portion are more crystalline in texture and apparently more basic.

The black obsidian of the Glass Buttes, to the northwest, and of Horse Mountain, to the southwest, is probably related to the Wagontire Mountain mass. 
Basalts. - The basalt of the main flows over the surface of the country is for the most part a dark-gray, fine-grained, rather vesicular rock, weathering on the more level areas into brown rounded cobbles and bowlders that make a very uneven surface, difficult to travel over.

On the higher peaks the more resistant types of this rock contain much iron and strongly affect the compass needle. Very little soil has formed over these high desert areas. Approximately parallel partings, usually at intervals of only a few feet, mark the division between successive flows, but in some places much thicker beds are exposed. Fissures nearly perpendicular to the parting planes break the basalt into blocks, which by transverse fracturing are reduced to smaller and smaller fragments, forming the characteristic talus slopes of the cliffs.

Tuffs.-In several places over the northern and western parts of the county there are remnants of a great tuffaceous flow or series of flows. This tuff underlies the upper flows of the basalt, but probably belongs to the same general period of effusion. Fort Rock (Pl. VII, $A$ ), an isolated mass in the northwestern part of Christmas Lake Valley, is the most prominent of these remnants. It is imperfectly crescent shaped, nearly one-third of a mile across, and rises in its highest part 325 feet above the valley floor, with perpendicular cliffs 200 feet above its talus slopes. The tuff of which it is composed is a tawny, rather firmly cemented material, consisting of fragments of effusive rocks and volcanic cinder. This material is largely used in the western part of the county for building purposes, being soft when first quarried and easily cut into blocks that harden on exposure, and as it is used especially for chimneys it is locally known as "chimney rock."

A thick tuff bed also exists in the mountains south of Paisley and is well exposed in the Chewaucan River canyon a short distance above the town. This tuff, which is colored various shades of red and blue, has been mineralized to some extent by quartz and calcite. Toward its southern end considerable prospecting for gold has been done, and good values are reported to have been found in some places. The remains of an old arrastre, half a mile below these workings show that for a number of years the locality has been prospected for the precious metal.

Interbedded with the basalts are thinner layers of tuff, or volcanic mud and ash. These are usually rather fine grained, white or red in color, and contain fragments of basaltic rocks. Where exposed along cliffs these tuff beds thin out, as if lenticular in shape, and in some instances serve to accentuate any unevenness in the associated basalt beds. 
These tuffs also exhibit interesting contact phenomena, as at North Alkali Valley, where a white tuff bed about 4 feet thick is exposed for several miles in the cliff along the eastern side of the valley. The contact with the underlying basalt is sharp and exhibits no alteration. From this line upward the color changes evenly through brown to black at the upper contact, where the tuff has been melted to a beady glass by the heat of the succeeding flow. This overlying rock is lighter colored and less dense than the usual basalt, and covers much of the area surrounding Alkali Lake basin, but it probably belongs to the same period of effusion as the more close-textured basalt to the south, into which it seems to grade.

\section{RECENT ERUPTIVE MATERIAL.}

In the northern part of the county is an area covered by sheets of lava and small volcanic cones or craters that represent a very recent period of volcanic eruption. Black vesicular basaltic rock constitutes the main part of the flow, while the cones are built up of slaglike fragments of scoria and volcanic bombs. This material clearly was ejected at a period much later than that of the great Miocene flows. It is probably Pleistocene in age.

\section{VALLEY FILLINGS.}

The loose Pleistocene filling of the valleys and the alluvial material brought down by streams may be considered as a fourth class of surface material in this region.

Lake deposits. - No marine beds were seen, but some lake deposits should be mentioned here. Along the hills east of Summer Lake, and fully 150 feet above its present level, there are beds aggregating 25 feet or more in thickness. These are composed of basaltic pebbles and shells of fresh-water mollusks, cemented into a conglomerate by lime carbonate.

Many of the stones around the borders of the lake basins are coated with a hard, white deposit of lime, in many cases half an inch thick. One mass of this material 10 or 15 feet in diameter, observed on the western edge of Summer Lake, is probably a tufa deposit of lime carbonate, such as Russell found so common along the shores of the ancient Lake Lahontan, in Nevada and California.

In all of the lake valleys there are deposits of silts, sands, and clays that form the floor of the valley and usually bury any coarser material that may be in the basin. Remains of Pleistocene mammals fix the age of these deposits at Fossil Lake, in Christmas Lake Valley, where somewhat extensive collections have been made by representatives of the Smithsonian Institution, and in 1904 by a party from the University of California. 
Alluvium.-Some alluvium is to be found where the several streams debouch into the open valleys, but in few places is the area thus covered of great extent. Probably at the mouth of the Chewaucan River canyon there is the largest area of this stream-deposited material. Here the gravel-covered terraces at Paisley have clearly been built by the river, probably as a delta in the former lake, and the low divide between Summer Lake and Chewaucan Marsh is largely if not entirely formed of river wash.

Honey Creek, in Warner Valley, has also brought down and deposited on the valley edge a large amount of gravel.

Landslides and the slower weathering action that produces talus have also brought down much loose material from all the cliffs and steep slopes, but the areas covered by such material are not large.

Although in comparison with the great rocky basaltic areas these loose materials are geologically of minor importance, it is from them that practically all of the limited quantity of ground water now used is obtained. Hence from the view point of the present water resources in the region this fourth class of unconsolidated material is perhaps the most important. The cultivable land is also limited to these areas of lake and stream deposits, so that the possible agricultura] portions of the county-neglecting alkaline conditions, which will be discussed in detail later-are shown on the geological map (Pl. VI) by the colors that represent these deposits.

\section{STRUCTURE.}

\section{FAULTS.}

Probably in but few other places in the world is the geologic structure so well exhibited in the present land forms as it is in southeastern Oregon. Here the main features of relief are a direct result of deformation of the rocks. This deformation has resulted in faults, which are the main structural features, as their expressions in scarps are the main topographic features.

In most of the Great Basin region the typical Basin Range structure, produced by the faulting and tilting of long, narrow orographic blocks, is largely obscured by erosion or by earlier complex structures. But in Lake County erosion has acted very little on these great blocks, and little or no deformation preceded the faulting, so that the typical structure is evident in the present conformation of the surface. The geologic cross section (see Pl. X) through Chewaucan Marsh, Lake Abert, and Warner Valley well exhibits this characteristic tilted block structure, and in Pl. VIII, reproduced from Russell's "Reconnaissance," the block between the marsh and Lake Abert is seen to be of this origin.

a Russell, I. C., Geological reconnaissance in southern Oregon: Fourth Ann. Rept. U. S. Geol. Survey, 1884 . 
In a general way the southern country is more broken by faults than the northern. This fact is not as evident from the map (PI. II) accompanying this report as it would be were more of the region to the east and north shown; still, it will be noticed that in the northern part of the area mapped prominent scarps are not in evidence, while they are in the southern portion.

\section{FOLDS.}

Besides these tilted blocks there are low folds in the bedded lavas. In the production of these, however, the rock itself has been bent little if any. The very slight opening and closing of the multitude of approximately vertical fractures in the beds has been sufficient to allow the low folds to be formed. In Lake County the other structural features seem closely related to a great upward fold or anticline of this character, which has been extensively faulted in places; and the structure of the region has been tentatively worked out on this assumption, as follows:

The axis of this major anticline extends from Silver Lake southward through Goose Lake Valley, approximately along the straight line $A-A^{\prime}$, Pl. VI. At its southern end the monoclinal slope at the western side of Goose Lake Valley and the steep slope at its eastern side suggest that here the anticline has broken down and that Goose Lake Valley lies, as it were, on the dropped keystone of an arch. (See section, Pl. X.) To the north dips in the beds indicate that Chewaucan River has cut its channel along the axis of the fold for a number of miles. Through Summer Lake Valley it appears that the anticline has again broken down, its western side remaining in place to form Winter Ridge, while the eastern is buried beneath the lake deposits. White Rock, a tuffaceous exposure in the bluff at the northwest side of the valley, seems closely to mark the northern point of this breaking down, for northward from it a very evident plunging anticline forms the slopes to Silver Lake. In the hills north of this lake the fold does not show.

The near parallelism of Elder Creek with the axis A-A' is also to be noted, and in a broader way the approximate parallelism of Chewaucan Marsh.

One of the areas examined in which the folds are irregular and complex in a minor way is that at the northern end of Summer Lake Valley. As indicated on the geologic map (Pl. VI), the dips of the beds on each side of Sheep Lick Draw show that a smaller fold, whose axis is $\mathrm{B}-\mathrm{B}^{\prime}$, exists here, which dies out toward the crest of the divide between Christmas Lake and Summer Lake valleys. This divide has the character of a cross anticline whose axis is $\mathbf{C}-\mathbf{C}^{\prime}$, and these three upward folds, together with the synclinal fold up whose trough 

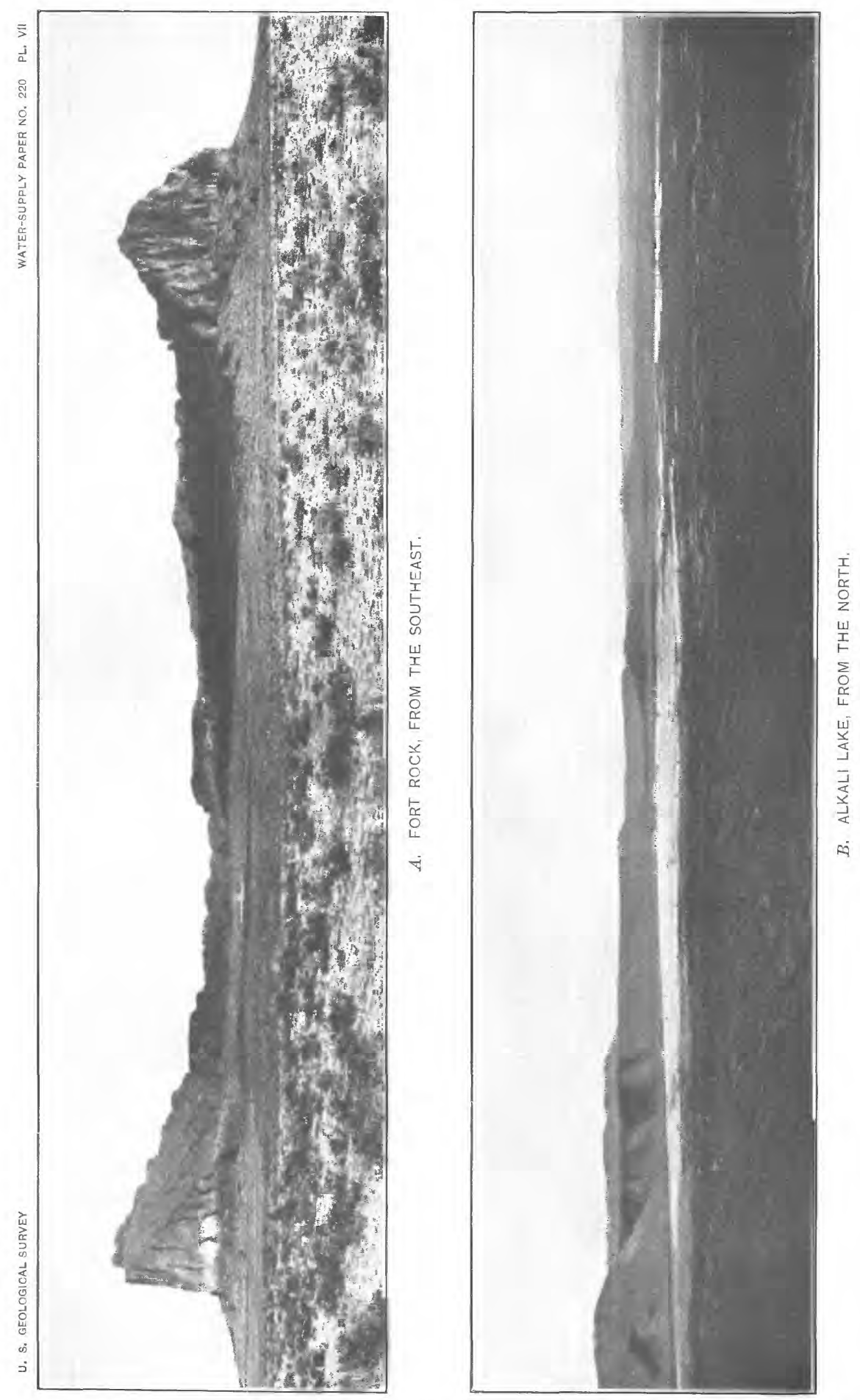

the county road between Summer Lake and Silver Lake passes, have produced a peculiarly warped surface.

In the southeastern part of the area studied the plateau between Goose Lake and Warner Lake valleys has the character of a wide, low syncline, while the dips on each side of southern Warner Valley indicate that, like Goose Lake Valley, it has been formed by the faulting of an anticline, as shown in the section through south Warner Valley (Pl.X). At its northern end the dips indicate more purely monoclinal faulting, as shown in the section through Chewaucan Marsh (Pl. X).

Over all of the northeastern part of the county the beds lie approximately horizontal, indicating, as before stated, that there has been less deformation in that region. Even at a short distance from the base of Wagontire Mountain the surface beds are nearly level.

There are many minor scarps, especially in the broken country northeast of Summer Lake and at the south end of Silver Lake. These, however, do not seem to be of fault origin, but are apparently weathering rather than structural features.

As in the topography the scarps were shown to be the main features, so the faults producing these scarps and their associated undrained basins are again emphasized as being the chief structural features. In this respect the low folds are treated as of secondary importance; for although, as tentatively shown, the structure has been determined largely by a great anticline which has collapsed in places, the most striking features along this fold are the results of faulting.

\section{PHYSIOGRAPHY.}

EARIY HISTORY.

In attempting to trace the development of the present topographic features of Lake County and vicinity it must first be considered at the period immediately following the outpouring of the great basaltic lava floods of Miocene time. Only the very scantiest and most fragmental evidence exists for deciphering the history of the region before this period, but data for unraveling the later evolution of the land forms are much more abundant.

At the close of the great lava outflow Lake County and the adjacent regions north and east probably formed one widely extended plateau, above which projected, like islands in the basaltic inundation, only isolated peaks of the former surface, such as Big Juniper and Little Juniper mountains, Gray Butte, and the Coyote Hills. There could have been little topographic diversity in the entire region, for the prominences mentioned were but minor elevations, widely scattered, and rising but little above the general broad levels. 
Drainage could not have been definite or well developed; indeed, if precipitation was as light then as it is at present, there were probably few streams in existence.

\section{DEFORMATION:}

Some time after this broad constructional plateau came into existence, at a time which can not be fixed definitely on the basis of any evidence gathered within Lake County, but which, to judge from similar events whose history has been more closely traced farther to the north and to the south, was in the Pliocene epoch, earth movements began that resulted eventually in the uplifting of the Cascade Range in the north and of the Sierras in the south. Although the locus of these movements, or the line of their greatest intensity, lay well to the west of the area under discussion, this area was itself markedly affected by them. The movements, whose axis of greatest intensity coincided roughly with the present crest of the Cascade Range, exhibited as they passed eastward a constantly diminishing intensity, so that here, while great mountain ranges did not come into existence as one of their products, the old plateau, which had existed before the disturbance, was extensively modified. This modification in various parts of the piedmont area at the eastern base of the Cascades took the form in some localities of low folds and resulting ridges, in others of faults of limited throw with a resulting appropriate topography, and in still others of a combination of faults and folds. Whatever form the movement took, it produced a marked change in the preexisting land forms.

In Lake County faulting seems to have been the dominant expression of this movement, although folding also took place. The great scarps which are so characteristic of the region and which limit practically all of its major depressions on one or the other side date from this period and are themselves due directly to the breaking of the lava beds, their broken edges now constituting the scarps in question.

The preexisting plateau was broken by these movements into a series of irregular blocks, some of which were dropped bodily and are limited by faults on either side, while others are tilted to the east or the west, giving structures that, since the work of Gilbert and Russell, have come to be known as Basin Range structures. In other parts of the area, especially farther north, where the movements seem to have been less intense or less definitely localized, broad ridges were raised without fracturing. Such a ridge is that which extends north of east from the vicinity of Squaw Peak through St. Patricks Mountain. This ridge separates Silver and Summer lakes, where it is clearly anticlinal in character, but eastward from this area it gradually dies out or becomes less definite as a structural feature. 


\section{PRESERVATION OF DEFORMATIONAL FEATURES.}

The topographic forms that resulted from this series of general crustal movements seem to have been preserved with comparatively little modification to the present day, and from this fact it appears that, though the region is one of light rainfall, so that the usual erosional forces operate with comparatively slight intensity, the movement must have been relatively recent. For had these forms existed for any extended time, even under desert conditions of minimum precipitation and minimum stream development, they would have been considerably modified. The greater scarps, like those which limit on the east the valleys in which lie Goose, Abert, and Alkali lakes, are comparatively unmodified. This is equally true of the scarps that confine the Warner Lakes on the east and of the somewhat less pronounced scarps that limit them on the west. Winter Ridge, to the west of Summer Lake, although it has been slightly modified by landslides since it came into existence, exhibits substantially its original form. The greatest evidence of the action of erosion or disintegration is found in a few localities like that at the south end of Silver Lake. Here exists a valley whose extension is occupied by Silver Lake, and scarps have been formed limiting this valley on both the east and the west that can not be accounted for as fault features, because Silver Lake and its valley seem to occupy the axis of an unbroken anticline. Rocks along its crest were presumably weakened and therefore easily subject to attack by disintegrating agents, and perhaps on this account these agents have been most effective here.

Over large areas in the northern part of the county, areas that are now known generally as the "high desert," the effect of the crustal movement that elsewhere produced the scarps and the valleys that accompany them seems to have been merely to warp slightly the original constructional plateau, so that it is now a high, rolling, irregular plain, changed scarcely at all from its original condition. Similarly the surfaces of some of the blocks whose edges form the conspicuous scarps--surfaces like that of the great ridge that separates Abert Lake and Warner Lake valleys-exhibit little change, other than the tilting they have suffered, from the original surface of the plateau from which they are derived. It is probable, indeed, that portions of these surfaces coincide with the surface that existed before deformation had affected the region at all. The faulting and folding, in other words, have deformed the surfaces as well as the rocks, and these deformed surfaces are the present topographic features of Lake and adjacent counties.

\section{EROSIONAL MODIFICATIONS.}

Where streams like Chewaucan River drain higher ridges in the western portion of the county-ridges that because of their great 
height have a greater rainfall and consequently a greater run-offgorges due to erosion have been formed, and other modifications of the original deformational surface are found. These modifications are usually greatest where the rocks were made more vulnerable to attack by erosional agents through weakening along fault lines or upturning along folds. At such places sharp canyons have developed that follow strike lines closely and have been cut out along weak zones in the disturbed rocks. But except near the western edge of the county, where these favoring conditions of high rainfall, sharp relief, and weakened rocks have combined to yield limited areas of topographic forms that are erosional instead of constructional, the surface of the county is almost exclusively dependent upon constructional forces.

\section{LAKES.}

Present lakes.-As an immediate result of the movements by which the ridges with their limiting escarpments and the valleys that lie at the bases of these escarpments were formed, the lakes that dot the surface of the county and give it its name came into existence at the lowest points of the deformed surface, from the accumulation there of such slight run-off as the meager rainfall of the region furnished. Each constructional basin has its own drainage, and the drainage accumulates at the lowest point within the basin. If it is more than sufficient to satisfy evaporation, a lake exists in the depression; if evaporation is as effective in removing the water as rainfall is in supplying it, playas or intermittent lakes, like Alkali Lake, result.

Quaternary lakes.-During Quaternary time the basins of Lake County contained much greater bodies of water than at present. These have left evidences of their former extent in the terraces or ancient shore lines cut in the surrounding hills, in the lake deposits, and, as at Paisley, in the formation of deltas rather than of alluvial fans opposite canyon mouths. At Willow Ranch, south of New Pine Creek, shells of fresh-water mollusks are said to be found 150 feet above the present lake surface. On the eastern side of Summer Lake Valley similar shells are found, and faint terraces along Chewaucan Marsh show that Lake Abert, the marsh, and Summer Lake were once continuous. According to Russell, ${ }^{a}$ the water once stood 260 feet deep over the marsh and 300 feet deep in Summer Lake Valley. Silver Lake and Christmas Lake valleys once formed a wide, continuous, rather shallow expanse of water; but the present small bodies are not to be considered as remnants of this former lake.

The most distinct terraces in the region are to be found in the hills surrounding the Alkali Lake basin. Several deeply cut notches in these hills show successive stages of the lake level, the highest being

a Russell, I. C., A geological reconnaissance in southern Oregon: Fourth Ann. Rept. U. S. Geol. Survey, 1884 , p. 459. 
275 feet above the present flat. The approximate extent of these Quaternary lakes is indicated by the areas of alluvium shown on Pl. VI.

\section{HYDROGRAPHY.}

STREAMS.

From the nature of the topography of this region, the area draining into each lake basin is rather limited, and the amount and character of the discharge depend almost wholly on local precipitation.

ABERT LAKE DRAINAGE.

Chewaucan River and its branches above Paisley form the largest drainage system in the county, with an area of about 272 square miles. Nearly all of this is in the higher, timbered region, where conditions are favorable for heavier precipitation and for the conservation of the rainfall and snowfall, hence the stream flows in good volume throughout the year. Near Paisley its canyon opens rather abruptly into the lake valley, and after flowing beyond its former delta deposit the water, except where carried off through drainage canals, sinks in Chewaucan Marsh. At the lower end of the marsh the water again rises, and after dropping over a low basaltic ledge empties into Lake Abert.

Several other smaller streams east of the upper portion of the Chewaucan basin carry northward much water from the mountains and join Chewaucan River before it reaches Lake Abert. Moss, Coyote, and Crooked creeks are the largest of these. Moss Creek, with from 30 to 40 miner's inches summer flow, drains only a small area, but its source in springs in the timbered mountains insures it a fairly reliable discharge. Near its entrance into the lower Chewaucan Valley part of the water is diverted to irrigate alfalfa and vegetables. Coyote Creek flows through a small open valley in the portion of its course between the mountain slopes and the gorge that carries it toward Lake Abert, but during the late summer a great part of its water sinks before reaching Chewaucan River. Crooked Creek in its course through its upper valley has cut a channel in the alluvial filling 20 feet or more deep, with vertical banks, and in its lower stretches it is confined in a narrow canyon until it reaches the more open valley a few miles south of Lake Abert. It unites with Chewaucan River just before the latter enters the lake.

SILVER LAKE DRAINAGE.

The drainage basin of Silver Creek is also mostly a timbered area, the stream being fed mainly by waters from the slopes south and southwest of Hager Mountain. Together with Bridge Creek and 
Bear Creek (locally known also as Buck Creek), two streams that drain the slopes farther to the west, it supplies Silver Lake. Like Chewaucan River, these streams sink in Pauline Marsh, and through it the water reaches Silver Lake.

SPRAGUE RIVER DRAINAGE.

The western edge of the county is drained either by Sprague River and its branches directly or through Sycan Marsh into this stream, whose waters finally discharge into Klamath Lake. This area is also mountainous and wooded, but drains westward, away from the region with which this paper is concerned.

GOOSE LAKE DRAINAGE.

A number of small streams flow into Goose Lake, the chief of these in Oregon being Drews and Cottonwood creeks. These have their sources in the wooded slopes of the northwestern side of the valley, but their waters generally sink in the lowlands before reaching the lake. Bullard Creek, near Lakeview, and Kelly Creek, near the town of New Pine Creek, are but small mountain streams, while in California a number of similar small intermittent streams carry the run-off from the sides of the narrow basin to the lake. A very low divide separates the south end of the lake from the north fork of Pit River, into which it has been known to overflow. The present lake surface is about 190 square miles in area, about 60 square miles of which is in Oregon.

STMMER LAKE BASIN.

Summer Lake, about 70 square miles in area, is largely independent of local run-off for its supply, for Ana River, its principal feeder, has its source in at least five large springs that rise in the sediments at the north end of the valley. The total flow of these springs is very constant, being, as measured by Mr. I. Landes, of the Reclamation Service, 148 to 150 second-feet, or 7,400 to 7,500 California miner's inches of 9 gallons a minute. Even during the dry season of 1887-8 it is said not to have decreased noticeably. Buckhorn and Johnison creeks have like sources in the sediments of the north end of the valley, but their waters sink before reaching the lake. Along the western side of the valley numerous streams rising in the slopes above flow into the lake, but the total discharge of the sixteen that were flowing measurably in September, 1906, was only 250 to 300 miner's inches, or about 4 per cent of that of Ana River.

WARNER VALLEY STREAMS.

Into Warner Valley only three streams of any consequence flow. Honey Creek enters the valley at its western edge, near Plush; Warner Creek also enters from the west, at Adel, while Twelvemile Creek 
flows into the south end of the valley at Warner Lake post-office. These are perennial streams, but they have only a small discharge, hardly sufficient to balance evaporation from the lake, which is now broken into several detached water bodies.

\section{NORTHERN DESERT AREA.}

In Christmas Lake Valley there are no perennial streams. Peter Creek, in the northern arm of this valley, is the nearest approach to a living stream, but even in the spring it often flows no farther south than its sink. Lost Creek is the largest stream in the northeastern part of the area visited, having a discharge of 10 to 15 inches in the fall of 1906. Northward it flows only to a playa near the base of North Glass Butte.

Three or four ranches have been taken up along the eastern side of Wagontire Mountain, where springs issue. Of these springs the largest is that at Antone Egli's, the water of which is used for irrigating alfalfa. Its flow in November, 1906 , was 8 .or 9 miner's inches. As this water has the highest electrical resistance of all of those tested, a sample of it was taken for analysis, the result of which is given on page 72 (sample B). The total solid content of only about 10 parts in 100,000 , or 5.84 grains to the gallon, shows it to be a very pure water.

\section{DISCHARGE MEASUREMENTS.}

During the last two years gaging stations have been kept by the United States Geological Survey on several of the streams of the county, the estimated discharges of which are given below.

Estimated monthly discharge of Chewaucan River at Paisley, a Oreg., in 1905 and 1906.

\begin{tabular}{|c|c|c|c|c|c|c|c|c|}
\hline \multirow{3}{*}{ Month. } & \multicolumn{4}{|c|}{$1905 . b$. } & \multicolumn{4}{|c|}{$1900 \mathrm{c} . c$} \\
\hline & \multicolumn{3}{|c|}{ Discharge in second-feet. } & \multirow{2}{*}{$\begin{array}{l}\text { Total in } \\
\text { acre-feet. }\end{array}$} & \multicolumn{3}{|c|}{ Discharge in second-feet. } & \multirow{2}{*}{$\begin{array}{l}\text { Total in } \\
\text { acre-feet }\end{array}$} \\
\hline & Maximum. & Minimum. & Mean. & & Maximum. & Minimum. & Mean. & \\
\hline January. & 332 & 53 & 94.1 & 5,786 & 111 & 46 & 65.9 & 4,050 \\
\hline February... & 111 & 23 & 64.6 & 3,588 & 111 & 46 & 62.6 & 3,480 \\
\hline March. & 223 & 64 & 136.0 & 8,362 & 739 & 68 & 173.0 & 10,600 \\
\hline April. & 318 & 131 & 230.0 & 13,690 & 837 & 211 & 563.0 & 33,500 \\
\hline May. . & 290 & 198 & 238.0 & 14,630 & 1,000 & 387 & 670.0 & 41,200 \\
\hline June.. & 318 & 53 & 154.0 & 9,164 & 649 & 259 & 415.0 & 24,700 \\
\hline July. & 64 & 23 & 33.2 & 2,041 & 234 & 37 & 110.0 & 6,760 \\
\hline August..... & 23 & 19 & 19.5 & 1,199 & 37 & 29 & 30.5 & 1,870 \\
\hline September.. & 36 & 19 & 23.5 & 1,398 & 68 & 29 & 37.9 & 2,260 \\
\hline October.... & 36 & 23 & 28.5 & 1,752 & 46 & 29 & 37.3 & 2,290 \\
\hline November.. & 36 & 23 & 29.7 & 1,767 & 68 & 37 & 47.8 & 2,840 \\
\hline December... & 223 & 23 & 70.8 & 4,353 & 81 & 23 & 52.1 & 3,200 \\
\hline The year $d$ & 332 । & 19 & 93.5 & 67,730 & 1,000 & 23 & 189 & 136,750 \\
\hline
\end{tabular}

a Gaging station established January 4, 1905. I. Landes, hydrographer.

$b$ Report of Progress of Stream Measurements for 1005. Water-Supply Paper No. 176, U. S. Geol. Survey, p. 135 .

c From unpublished records of United States Geological Survey furnished by J. C. Stevens, district hydrographer, Portland, Oreg.

$d$ Ice gorge January 10-31; discharge, assumed 77 second-feet. Ice conditions for remainder of winter months not known; open channel rating table applied. 
Estimated monthly discharge of Silver Creek near Silver Lake, ${ }^{a}$ Oreg., in 1905 ant 1906.

\begin{tabular}{|c|c|c|c|c|c|c|c|c|}
\hline \multirow{3}{*}{ Month. } & \multicolumn{4}{|c|}{1905.6} & \multicolumn{4}{|c|}{$1906 . c$} \\
\hline & \multicolumn{3}{|c|}{ Discharge in second-feet. } & \multirow{2}{*}{$\begin{array}{l}\text { Total in } \\
\text { acre-feet. }\end{array}$} & \multicolumn{3}{|c|}{ Discharge in second-feet. } & \multirow{2}{*}{$\begin{array}{l}\text { Total in } \\
\text { acre-feet. }\end{array}$} \\
\hline & Maximum. & Minimum. & Mean. & & Maximum. & Minimum. & Mean. & \\
\hline January & 70 & 24 & 36.8 & 2,263 & 50 & 80 & 24.1 & 1,480 \\
\hline February & 137 & 21 & 43.9 & 2,438 & 78 & 7 & 27.6 & 1,530 \\
\hline March & 155 & 54 & 73.9 & 4,544 & 212 & 10 & 40.4 & 2,480 \\
\hline April. & 203 & 46 & 89.9 & 5,349 & 530 & 57 & 320 & 19,000 \\
\hline May... & 87 & 27 & 47.2 & 2,902 & 246 & 43 & 118 & 7,260 \\
\hline June. & 39 & 21 & 27.8 & 1,654 & 106 & 21 & 45.7 & 2,720 \\
\hline July. & 21 & 13 & 16.7 & 1,027 & 86 & 12 & 31.3 & 1,920 \\
\hline August. & 19 & 15 & 17.1 & 1,051 & 15 & 12 & 12.5 & 769 \\
\hline September... & 19 & 15 & 15.4 & 916 & 15 & 12 & 12.9 & 768 \\
\hline October..... & 21 & 15 & 15.7 & 965 & 13 & 12 & 12.0 & 738 \\
\hline November... & 42 & 13 & 21.4 & 1,273 & 26 & 5 & 12.7 & 756 \\
\hline December.... & 36 & 13 & 21.6 & 1,328 & 31 & 5 & 13.5 & 830 \\
\hline The year $d$. & 203 & 13 & 35.6 & 25,710 & 530 & 5 & 55.7 & 40,251 \\
\hline
\end{tabular}

$a$ Station established December 29, 1904. I. Landes, hydrographer.

$b$ From Water-Supply Paper No. 176, U. S. Geol. Survey, p. 129.

c From unpublished records of United States Geological Survey, furnished by J. C. Stevens, district hydrographer, Portland, Oreg.

$d$ Ice is known to form at this station during winter months, but the observer failed to note the length of time that ice conditions existed during 1905 . The open channel rating table was applied to the winter months without correction.

Estimated monthly discharge of Bridge Creek near Sitier Lake, a Oreg., in 1905 and 1906.

\begin{tabular}{|c|c|c|c|c|c|c|c|c|c|}
\hline \multirow{3}{*}{ Month. } & \multicolumn{4}{|c|}{$\overline{1905 . b}$} & \multirow{3}{*}{ Month. } & \multicolumn{4}{|c|}{$1906 . c$} \\
\hline & \multicolumn{3}{|c|}{$\begin{array}{l}\text { Discharge in second- } \\
\text { feet. }\end{array}$} & \multirow{2}{*}{$\begin{array}{l}\text { Total in } \\
\text { acre-feet. }\end{array}$} & & \multicolumn{3}{|c|}{$\begin{array}{l}\text { Discharge in second- } \\
\text { feet. }\end{array}$} & \multirow{2}{*}{$\begin{array}{l}\text { Total in } \\
\text { acre-feet. }\end{array}$} \\
\hline & $\begin{array}{l}\text { Maxi- } \\
\text { mum. }\end{array}$ & $\begin{array}{l}\text { Mini- } \\
\text { mum. }\end{array}$ & Mean. & & & $\begin{array}{l}\text { Maxi- } \\
\text { mum. }\end{array}$ & $\begin{array}{l}\text { Mini- } \\
\text { mum. }\end{array}$ & Mean. & \\
\hline \multirow{3}{*}{$\begin{array}{l}\text { January } 21-31 \ldots \\
\text { February } 1-19, \\
24-28 \ldots \ldots \ldots\end{array}$} & 8.1 & 2.0 & 4. 55 & 99 & Januar & 21 & 11 & 16.6 & 1,020 \\
\hline & & & & & Febru & 21 & 11 & 17.1 & 950 \\
\hline & 10.0 & 1.2 & 4. 33 & 206 & March. & 14 & 4 & 10.4 & 640 \\
\hline March. & 2.8 & 1.2 & 2. 23 & 137 & April. . & 23 & 7 & 10.5 & 625 \\
\hline April. & 6.6 & .8 & 2. 53 & 151 & May... & 29 & 14 & 21.1 & 1,300 \\
\hline May.. & 12.9 & 1.3 & 7.79 & 479 & June. & 22 & 15 & 18.7 & 1,110 \\
\hline June..... & 15.2 & 3.0 & $\therefore 0.0$ & 631 & July $1-21 .$. & 25 & 6 & ........... & \\
\hline July $1-6 .$. & 3. 0 & .6 & 2.18 & 26 & & & & & \\
\hline August $7-31 \ldots$ & .8 & .2 & .46 & 23 & & & & & \\
\hline September. & .7 & .6 & .66 & 39 & & & & & \\
\hline October... & .9 & .6 & .73 & 45 & & & & & \\
\hline November & 1. 5 & .7 & .95 & 57 & & & & & \\
\hline December $d$ & 1.3 & .2 & 1.00 & 61 & & & & & \\
\hline
\end{tabular}

a Station established January 21, 1905. I. Landes, hydrographer.

$b$ From Water-Supply Paper No. 176. U. s. Geol. Survey, p. 131.

c From unpublished records of United States Geological Survey, furnished by J. C. Stevens, district hydrographer, Portland, Oreg.

$d$ Ice conditions December $17-31$; discharge estimated, 1.3 second-feet.

\section{Discharge measurements of Bear Creek near Silver Lake, Oreg., in 1905.b}

January 24.

14.4

February $23 c \ldots \ldots \ldots \ldots \ldots \ldots \ldots \ldots \ldots \ldots$

March $17 d$........................... 11

August $7, \ldots \ldots \ldots \ldots \ldots \ldots .6 .3$

May 31 e.......................... 50.0

October $4 \ldots \ldots \ldots \ldots \ldots \ldots \ldots \ldots .5 .0$

October $24 \ldots \ldots \ldots \ldots \ldots \ldots \ldots \ldots \ldots, 6.4$

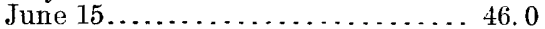

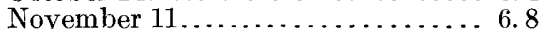

a Station established January 21, 1905, at County Bridge. I. Landes, hydrographer. Results for 1906 unsatisfactory, and station discontinued.

$b$ From Water-Supply Paper No. 176, U. S. Geol. Survey,Ip. 131.

c 500 feet below bridge.

$d 400$ feet below bridge.

$e 100$ feet above bridge.

$f 300$ feet below bridge. 
Approximate annual discharye of the several streams of Lake County, Oreg., in 1905 and 1906.

\begin{tabular}{|c|c|c|c|c|c|}
\hline \multirow[b]{2}{*}{ Stream. } & \multirow{2}{*}{$\begin{array}{c}\text { Approxi- } \\
\text { mate area of } \\
\text { drainage } \\
\text { wasin in } \\
\text { square miles. }\end{array}$} & \multicolumn{2}{|c|}{1905.} & \multicolumn{2}{|c|}{1906.} \\
\hline & & $\begin{array}{l}\text { Discharge } \\
\text { for year in } \\
\text { acre-feet. }\end{array}$ & $\begin{array}{l}\text { Run-off in } \\
\text { inches } \\
\text { (to nearest } \\
\text { tenth). }\end{array}$ & $\begin{array}{l}\text { Discharge } \\
\text { for year in } \\
\text { acre-feet. }\end{array}$ & $\begin{array}{l}\text { Run-off in } \\
\text { inches } \\
\text { (to nearest } \\
\text { tenth). }\end{array}$ \\
\hline 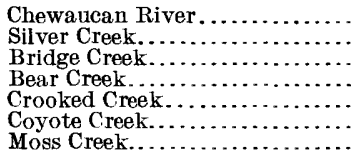 & $\begin{array}{r}272 \\
221 \\
45 \\
62 \\
95 \\
47 \\
16\end{array}$ & $\begin{array}{r}a 67,730 \\
a 25,710 \\
b 2,100 \\
b 12,600 \\
c 12,000 \\
c 2,000 \\
c 1,500\end{array}$ & $\begin{array}{r}4.7 \\
2.2 \\
.9 \\
3.8 \\
2.4 \\
.8 \\
1.8\end{array}$ & $\begin{array}{r}a 136,750 \\
a \mathbf{4 0}, 251 \\
b \mathbf{6}, 650 \\
c 18,500 \\
c 17,750 \\
c 3,300 \\
c 2,200\end{array}$ & $\begin{array}{l}9.4 \\
3.4 \\
2.8 \\
5.6 \\
3.5 \\
1.3 \\
2.6\end{array}$ \\
\hline
\end{tabular}

a From measurements of United States Geological Surver.

$b$ By interpolation in the incomplete records of the United States Geological Survey.

c Estimated by comparison with discharges of Silver and Bridge creeks.

\section{CHARACTER OF DISCHARGE.}

In the monthly stream-discharge tables a fact worthy of mention may be noted. The time of greatest discharge of Chewaucan River is during April and May, its maximum being reached in the latter month. Silver Creek, being smaller and draining less mountainous country, would be expected to reach its maximum flow somewhat earlier, as it does, in April. But Bridge Creek, with a drainage basin of only 45 square miles, does not reach its highest period until May or June. This is probably to be accounted for by the fact that its supply comes chiefly from the north slope of Yamsay Mountain, where melting of the snow is slower than on the eastern slopes drained by Silver Creek.

Another peculiarity, not explainable from the data at hand, concerning Bridge Creek is that, although judging from the records kept at Lakeview and Silverlake the precipitation was only about 50 per cent more in 1906 than in 1905, the total discharge of this stream, as shown by the figures of approximate discharge given above, was more than three times as great, so that the ratio of run-off to precipitation within its basin about doubled. For the other streams the discharge during 1906 was, like the precipitation, roughly 50 per cent greater than that of 1905 , so that the run-off ratio remained about the same during these two years.

\section{RUN-OFF RATIOS.}

Much study has been given to the relation of rainfall to run-off, and attempts have been made to deduce formulas for determining their ratios in different regions. So many complex conditions influence the run-off, such as amount, intensity, and distribution of rainfall, nature of soil, slope of surface, area and configuration of basin, as well as 
geologic structure, forest, wind, etc., that the ratio can be stated only in a very general way."

Newell ${ }^{b}$ gives general curves showing the ratio, and they indicate that for a region like southern Oregon, in which the precipitation in the higher drainage basins is probably from 15 to 20 inches, the run-off is usually between 3 and 5 inches.

The amount of run-off deduced in the table on page 35 from the estimates of approximate discharge departs from these figures in several cases, but in those records that are considered the most reliable the run-off agrees fairly well with this general ratio of one-fifth to onefourth.

Since no records of precipitation have been kept on the higher areas, the apparent departures from this ratio may fairly be assumed to be due, in part at least, to uneven distribution of the snowfall within the several drainage basins.

\section{EFFECT OF FORESTS.}

Because rainfall is most abundant in forested regions many believe that forests exert an influence favorable to precipitation. While they may have an appreciable cooling effect on the air, aiding to reduce the temperature below the dew point and thus to produce rain, the evidence on this matter is so conflicting that definite conclusions can not yet be reached. It seems more reasonable, however, to believe that abundant rainfall is the great factor in controlling the distribution and density of forests, rather than that the forests cause greater rainfall.

Although the relation of forests to rainfall and run-off is a complex problem, into which enter the factors of climate, topography, geography, and geology, there is no doubt whatever that the forests store a part of the rainfall in their spongy soil and loam, whence it enters the streams gradually rather than suddenly, and that they protect the accumulations of snow from rapid melting and evaporation; therefore the preservation of the forests is of vital importance.

A large part of the precipitation on all areas is returned to the air by evaporation. From the tree crowns immediately after a storm this return is, of course, very rapid, but the amount thus evaporated is only a small fraction of the total precipitation. From the forest-covered soil evaporation is comparatively slow, because the soil is protected from sun and wind, and the amount of moisture absorbed by a forest to supply the plant needs is probably less than that needed by the average agricultural crop. The total quantity annually returned to

a Rafter, George W., Relation of rainfall to run-off: Water-Supply Paper No.80, U. S. Geol. Survey, 1903, p. 9 .

b Newell, F. H., Results of stream measurements: Fourteenth Ann. Rept. U. s. Geol. Survey, pt. 4, 1894, p. 151 . 
the atmosphere from a forest by transpiration through the stems and leaves and by evaporation from the trunks and from the soil has been estimated at 75 per cent of the precipitation, while for fields of cereals and grasses it may be even more, in regions where from a bare field the evaporation may be only 30 per cent of the precipitation. ${ }^{a}$ But the amount of moisture annually evaporated from forest-covered soils and transpired by the trees themselves is only about half as great as that from open fields having a moderate covering of herbage. ${ }^{b}$

On the other hand, in regions of scanty rainfall, where a short wet season is followed by a long dry one, evaporation from the forest soil may go on slowly throughout nearly the whole year, while in the open, during a great part of the year, there is very little moisture to be evaporated and therefore little loss by transpiration from the scanty herbage, so that in such a case the forest-covered soil may lose more moisture by evaporation and transpiration than the open field. The spongy forest soil also, by retaining a large part of the scanty rainfall, lessens the stream flow from such an area. This is notably the case in many parts of the arid West.

The greatest collateral usefulness of a forest, however, lies in its power to regulate the run-off and to maintain a more equable flow of the streams. This it does by decreasing the surface run-off of flood waters and by increasing the seepage run-off from the saturated soil, which is the water that sustains stream flow. This is of far greater benefit than would be the extra water carried off by streams to the valleys below if the slopes were cleared. Indeed, usually the greater run-off of cleared areas is in the form of violent and destructive floods. A regulated flow, even though the total discharge may be less than the sum of a succession of floods, is vastly more beneficial, for "It is the amount of water that passes into the soil, not the amount of rainfall, that makes a region garden or desert." c

Minor but important effects of forests are protection from wind erosion as well as from erosion by water, prevention of snow slides in some localities, moderation of extremes of temperature, and, perhaps, distribution, if not increase, of precipitation.

\section{LAKES.}

CHANGES IN SURFACE LEVEL.

On account of the shallowness of the water bodies of Lake County the water level of the lakes can fall but little without destroying them. Such occasional dryings up have no doubt occurred within recent times. The best-known instance is that of Silver Lake. In

a Fernow, B. E., Economics of Forestry, New York, T. Y. Crowell \& Co., 1902, p. 438.

$b$ Ibid, p. 437.

c Toumey, James W., The relation of forests to stream flow: Yearbook U. S. Dept. Agriculture for 1903, p. 288. 
1879 Cope found Thorn Lake dry and Silver Lake low, but Russell states that during the following three years the surface of Silver Lake rose 6 feet and in 1882 was confluent with that of Thorn Lake. As has been stated, in 1888-89 Silver Lake completely dried up, which required a change in level during these six or seven years of at least 10 feet, for Russell stated that in June, 1882, when confluent with Thorn Lake, it was only 10 feet deep. In 1890 it again began to fill, and during the fall of 1906 the gage board established by the Reclamation Service indicated about 13 feet, but it was not learned whether this was supposed to be the depth of the lake.

It is claimed that Thorn Lake is supplied only by precipitation and occasional overflow from Silver Lake. As such overflow does not take place every year, evaporation would more than counterbalance these two sources of supply, and it therefore seems probable that it is fed by springs beneath its surface, like those at Christmas and Fossil lakes. The effect of the dry season of $1887-88$ on all of the lakes would be useful for comparison, but it is not known; it was only learned through hearsay that Summer Lake shrank little, if at all.

Noted changes in the level of Summer Lake are not recorded, but from the nature of the alkaline wastes along its eastern side it would appear that it is slowly shrinking.

The northern end of the Abert Lake basin is so nearly level that it is said that a strong south wind often forces the water back nearly 2 miles over the alkaline flat; so it seems very probable that seasonal changes shift the northern margin considerably.

Goose Lake experiences differences in its level, but fluctuates more slowly than the smaller lakes. The story that in the early sixties an emigrant trail crossed its valley at a place where the water is now several feet deep indicates that the lake was then smaller than at present, but a few years later it rose so as to extend several miles farther north than it now extends, and for a short time (in 1869) it overflowed southward'down Pit River. Since then it has shrunk, and is apparently still growing smaller.

The litigation in Warner Valley strongly emphasizes the fact that this lake has been shrinking since 1860 , but at what rate can not be said, as there are no recorded observations and seasonal differences obscure the slower general change.

The Alkali Lake drainage basin has an area of about 300 square miles, but it is all desert; no perennial streams exist in it, and consequently the depression, except for a few pools, is dry during a large part of the year.

ANNUAL SURFACE INFLOW.

With the meager discharge measurements given on pages 33-34 as a basis, the mean annual flow into each of the lakes has been estimated as well as may be, and comparison of inflow with drainage area and 
lake surface has led to some interesting conclusions. The areas of the drainage basins and of the lake surfaces can be obtained approximately from the map (Pl. II). Aside from the discharge tables given, data for estimating the inflow to the several lakes are lacking; but by comparing the observed width, depth, and velocity of other streams with the measured ones, a rough estimate of the stream discharge into each basin has been made and the following tables have been prepared.

The average rainfall records of 16.73 to 17 inches at Lakeview and 10.06 to 10.4 inches at Silver Lake given on pages 15-16, are for periods of twenty-two years at Lakeview and thirteen years at Silver Lake; and it has been estimated " that averages based on such lengths of time may differ from the final average by only about 3 per cent and 5 per cent respectively.

The stream-gaging record for 1905 is that for a year of 9.92 inches precipitation at Lakeview and 7.78 (?) inches at Silver Lake, or only about two-thirds of the average; but for 1906 the precipitation was 19.24 inches at Lakeview and 11.58 inches at Silver Lake, figures not greatly exceeding the average. So for the purpose of estimating the flow into each lake, the observed and estimated discharge records for 1906 have been used, since they are probably as close to the average as can be approximated.

From the average precipitation records an annual total of 14 inches upon the open surface of Goose Lake has been thought reasonable, while 12 inches has been assumed as the average annual precipitation. upon the surfaces of the lower lakes-Sunmer, Silver, and Abert.

All of the following estimates are necessarily very general, being based on general data; still, for the facts they are meant to indicate, it is thought that the figures given are sufficiently accurate.

The annual surface flow into the several lakes was computed from the following estimated stream discharges, which were based on the character and size of the drainage areas of the several streams, as compared with the streams whose discharges have been measured.

Annual discharge of streams flowing into Goose Lake.

Acre-feet.

Cottonwood Creek................................. 6, 000

Drews Creek...................................... 18, 000

Dry Creek.................................. 1, 1,000

Stream in Warner Canyon.......................... 2, 000

Bullard Creek.................................. 1,000

Kelly Creek................................. 2,000

Sixteen streams in California with aggregate drainage area of about 250 square miles (taken from Alturas sheet of U. S. Topographic

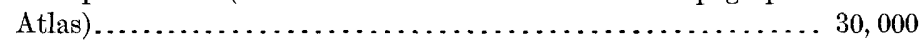

60,000

$a$ Rafter, George W., Relation of rainfall to run-off: Water-Supply Paper No. 80, U. S. Geol. Survey, 1903 . p. 18. 
Annual discharge of streams flowing into Abert Lake.

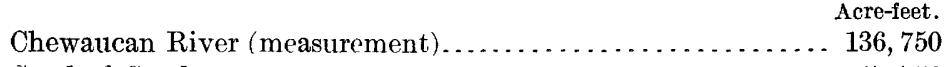

Crooked Creek.................................. 17,750

Coyote Creek................................. 3,300

Moss Creek.................................. 2,200

Annual discharge of streams flowing into Summer Lake.

160,000

Acre-feet.

Ana River (150 sec.-ft., measurement) ................ 109, 500

Johnson Creek (20 sec.-ft.)......................... 14,600

Total of other streams (10 sec.-ft.), partial measurement...... $\quad 7,300$

Annual discharge of streams flowing into Sitver Lake.

131,400

Acre-feet.

Silver Creek (measurement)

40,250

Bridge Creek (partial measurement) $\ldots \ldots \ldots \ldots \ldots \ldots \ldots \ldots \ldots .6,650$

Bear Creek (partial measurement) ................. 18,500

65,400

As before stated, the annual precipitation on the surface of Goose Lake was taken as 14 inches; on the surface of the other lakes, 12 inches.

EVAPORATION RATES.

In the following table it is shown that the ratios of the area of each lake surface to its drainage basin differ greatly, and that the annual increment, expressed in feet of water on its surface, is also apparently very different for the several lakes. On the assumption that evaporation balances the inflow, the increment also represents the annual evaporation rate.

Areas of lakes and lake basins, and annual surface supply.

\begin{tabular}{|c|c|c|c|c|c|}
\hline Lake. & $\begin{array}{l}\text { face in } \\
\text { square } \\
\text { miles. } a\end{array}$ & $\begin{array}{l}\text { cluding } \\
\text { lake) in } \\
\text { square } \\
\text { miles. } . a\end{array}$ & $\begin{array}{l}\text { face to en- } \\
\text { tire drain- } \\
\text { age basin. }\end{array}$ & $\begin{array}{l}\text { plus direct } \\
\text { precipitation } \\
\text { into lake, in } \\
\text { acre-feet. }\end{array}$ & $\begin{array}{l}\text { as feet in depth } \\
\text { over the lake } \\
\text { surface. } b\end{array}$ \\
\hline \multirow{2}{*}{ Goose.. } & \multirow{2}{*}{190} & \multirow{2}{*}{1,065} & \multirow{2}{*}{$0.18\left(\frac{1}{5}\right)$} & $\begin{array}{r}60,000 \\
142,000\end{array}$ & \multirow{2}{*}{1.66} \\
\hline & & & & 202,000 & \\
\hline \multirow[t]{2}{*}{ Abert.. } & \multirow[t]{2}{*}{60} & \multirow[t]{2}{*}{900} & \multirow[t]{2}{*}{$.07\left(\frac{x}{15}\right)$} & $\begin{array}{r}160,000 \\
38,400 \\
\end{array}$ & \multirow[t]{2}{*}{5.17} \\
\hline & & & & 198,400 & \\
\hline \multirow[t]{2}{*}{ Summer. } & \multirow[t]{2}{*}{70} & \multirow[t]{2}{*}{550} & \multirow[t]{2}{*}{$.13\left(\frac{1}{8}\right)$} & $\begin{array}{r}131,400 \\
44,800 \\
\end{array}$ & \multirow[t]{2}{*}{3.94} \\
\hline & & & & 176,200 & \\
\hline \multirow[t]{2}{*}{ Silver... } & \multirow[t]{2}{*}{15} & \multirow[t]{2}{*}{500} & \multirow[t]{2}{*}{$.03\left(\frac{1}{33}\right)$} & $\begin{array}{r}65,400 \\
9,600\end{array}$ & \multirow[t]{2}{*}{7.81} \\
\hline & & & & 75,000 & \\
\hline
\end{tabular}

$a$ Taken from map by measurement with planimeter.

b Inflow plus direct precipitation (in acre-feet), divided by area of lake, in acres. 
Evaporation experiments covering a period of five years at Fort Douglas, Utah, determined the yearly evaporation there as being 42.46 inches. As computed by the Signal Service, the rate at that place is 74.4 inches. $^{a}$

From a series of observations upon the rate of lowering of the level of Crater Lake, and from experiments to determine the rate of evaporation from its surface, Diller ${ }^{b}$ concluded that, allowing for escape by seepage, the average rate was about 53 inches annually, the surface reaching its highest level early in May and its lowest turning point about the 1st of October. Gannett some years earlier placed the rate of evaporation from this lake at 40 to 50 inches. Crater Lake is in nearly the same latitude as the water bodies of Lake County, but is 1,600 to 1,900 feet higher, and by virtue of the lower temperature of the surrounding air and because of its protecting walls, presumably is not subject to so rapid evaporation. Recent evaporation experiments at Keno, near Klamath Lake, Oregon, indicate an evaporation rate of about 40 inches annually at that place. ${ }^{c}$

Other evaporation data for comparison are very meager, but it seems that from the water bodies of Lake County the rate is probably somewhat greater than from Crater Lake, or than at Keno, which is more closely surrounded by forested mountains than are the water bodies of Lake County.

In estimating the increment to the four lakes considered, and hence the approximate annual evaporation from their surfaces, no account could 'be taken of escape by percolation or leakage from their basins, for there was nothing to indicate the amount thus lost, if any at all; neither could an estimate be made of the amount evaporated from the marshes. Leakage may perhaps account in part for the large apparent increment of 7.8 feet to so small a water surface as that of Silver Lake, and also for the fact that this lake dried up so quickly after the dry season of 1887-88. Evaporation from Pauline Marsh also no doubt materially lessens the apparent increment to this lake, a part of the stream discharge being evaporated before reaching the lake.

From Chewaucan Marsh there is also probably much evaporation, so that Lake Abert does not receive so great an increment as is credited to it.

Summer Lake, with the great springs of Ana River pouring into it, has an apparent increment of about 4 feet. The existence of the

a Newell, F. H., Results of stream measurements: Fourteenth Ann. Rept. U. S. Geol. Survey, 1894, p. 154. The results of experiments at Fort Bliss, Tex., given with those of Fort Douglas, are not quoted nere, as they are for a region of higher mean temperature than that of southeastern Oregon.

$b$ Diller, J. S., and Patton, H. B., Geology and petrography of Crater Lake National Park: Prof. Paper No. 3, U. S. Geol. Survey, 1902, p. 61.

c Clapp, W. B., and Hoyt, J.C., Progress of stream measurements for 1905: Water-Supply Paper No. 177 , U. S. Geol. Survey, 1906, p. 242. 
great springs feeding it renders very plausible the theory that other springs than those known discharge into this basin. The marshy nature of Thousand Spring Valley, however, indicates that this concealed supply may be by seepage over a considerable area, rather than by concentrated flowing springs. This assumption is strengthened by the fact that, according to notes of the Reclamation Service, on August 17, 1904, the discharge of Ana River near its source was only 155 second-feet, while near its mouth the discharge was 179 second-feet, indicating the accession to it of seepage waters or waters from other springs.

Rate of evaporation is a subject comparatively little studied as yet; results of experiments are meager, and the methods employed are unsatisfactory. Observations on the rate from pans or from inclosed basins usually give figures too large. It seems, however, that the rate from the water bodies of Lake County is probably greater than that observed at Keno-about 40 inches, and possibly more than 53 inches, the rate given by Diller for Crater Lake; but in the following discussion the conservative estimate of 40 inches will be taken.

\section{SUBSURFACE INFLOW TO GOOSE LAKE.}

Goose Lake, it will be noticed from the table on page 40, occupies one-fifth of its entire drainage basin. A glance at the index map (Pl. I), on which the limits of the several lake basins under discussion are shown by dotted lines, will emphasize the disproportionate area of Goose Lake with respect to its drainage basin, as compared with the other lakes. Its estimated supply or increment is only 1.66 feet (19.92 inches) annually, and the consequent evaporation rate is seemingly a little less than one-half of that assumed, which is almost certainly not the case. Neither leakage from the basin nor evaporation from the marsh land near Lakeview can be assumed to account for this discrepancy, for the problem is one involving not an excessive loss but a greater inflow than is in evidence.

It is recognized that the estimate of the surface inflow to Goose Lake may be 100 per cent or more in error, but even if the inflow is twice as great as has been assumed it will not materially affect the result, giving an apparent increment (and evaporation rate) of only 2.15 feet (25.8 inches) a year, for the surface inflow from the tributary streams is so much less than the direct precipitation on the lake surface that doubling the former does not greatly change the amount chargeable to evaporation.

The best explanation left to account for the discrepancy seems to be that the lake has a great constant source of supply beneath its surface. The several hot springs along the eastern side of its valley render it not improbable that other waters rise along the fault zone 
that is believed to exist here and supply the needful extra inflow. With an annual increment of 2.15 feet, which assumes twice the inflow from surface streams that was considered in the table on page 39, a supply from subsurface springs of about 144,000 acre-feet annually, or nearly 200 second-feet, is necessary to admit of an evaporation rate of 40 inches.

If the computed inflow from the tributary streams, 1.66 feet, be taken as a basis, and an evaporation rate of 4 feet be assumed (which seems reasonable from the more open nature of the Goose Lake basin as compared with conditions at Keno), the necessary supply becomes nearly twice as great. Even the smaller of these estimates is a larger amount than the discharge of Ana River and may seem a great deal to be supplied by springs beneath the surface of the lake; but the Ana River springs would flow nearly the same if Summer Lake extended northward so as to submerge them, and they probably did flow even stronger than they do now when the lake occupied its entire basin.

Fall River, 70 miles southwest of the lower end of Goose Lake, has its source in springs discharging 1,500 second-feet, or ten times the flow of Ana River. ${ }^{a}$

In the above discussion of the water bodies the most interesting thing brought out is this apparent great subsurface supply of Goose Lake. While the reasoning is admittedly based on little concrete data, the weakest point, that of the amount of its surface inflow, is shown to be really a minor factor in the computation, and hence the deductions are considered worthy of presentation.

\section{HYDROLOGY.}

\section{GENERAL STATEMENT.}

As distinguished from hydrography, which deals with the streams and their flow, the hydrology, or underground waters, of the county will now be discussed.

Waters that exist beneath the surface of the earth may in general be separated into two classes - those that are found in unconsolidated material, relatively near the surface, and those that circulate within consolidated rocks, generally at greater depths. Between the typical examples of each there are many differences, but in less well differentiated cases there may be no good lines of distinction, so that some subsurface waters might well be placed under either head.

$a$ Hoyt, J. C., and Clapp, W. B., Progress of stream measurements for 1905: Water-Supply Paper No. 177, U. S. Geol. Survey, 1906, p. 133. 
SHALLOW WATER.

\section{UNCONSOLIDATED DEPOSITS.}

That usually considered as ground water is found at moderate depths below the surface, in the gravels, sands, and silts of stream valleys, the alluvial material at mountain bases, or the accumulated sediments of lake valleys. In many regions, also, the decay of the country rock to a residual soil results in a loose porous layer that catches and holds a part of the rainfall and furnishes a supply of water for shallow wells.

Thickness and processes of formation.-The depth of loose material, either transported or produced in place by disintegration, depends on the climate, the character of the rock, and other factors, as well as on the surface features of the land. In humid climates, where vegetation is rank, rapid decay of the rocks takes place, this decay being aided by the organic acids formed in decomposing vegetal matter, by the abundant water that carries them downward, and by the disintegrating gases, like oxygen, that the water often contains. J. W. Spencer ${ }^{a}$ states that in the region about Atlanta, Ga., the rocks are "completely rotted" to a depth of 95 feet, while "incipient decay" may reach to 300 feet; and it is estimated that in some parts of Brazil such agencies have caused the decay of granite to a depth of 1,000 feet or more.

In arid regions, where conditions are less favorable to rock decay through the action of chemical agents, rock removal and the resulting accumulation of débris are largely physical processes. Rapid changes of temperature break up the rock masses, because of the unequal expansion of the minerals of which they are composed, while the winds and the occasional torrential rains carry the disintegrated material to the lower areas, where it accumulates as talus, alluvium, loess, or lacustrine deposits. In addition to its function as a transporting agent, wind also acts powerfully in certain localities as an agent of erosion. The strong wind, laden with particles of dust and sand, becomes an effective natural sand blast and wears away exposed rock surfaces with great rapidity, and the fine particles thus removed accumulate as a part of the mass of loose material in the lowlands.

Ground-water level.-Where the soil has accumulated to sufficient thickness as a result of any or all of these processes, direct precipitation and the inflow from streams keep it saturated below a certain level, except in the most arid districts. This ground-water level is not fixed, but varies with the seasons and with the supply. Its surface has a very definite relation to the land surface, which it resembles in a general way, but it does not rise so high in the hills and oftendoes 
not sink so deep in the valleys. Where the land surface intersects the surface of the ground water, as in deep valleys or gorges, springs issue, and as the ground-water level varies with the season these springs fluctuate, drying up when the level of their supply falls below the bottom of the valley and increasing their flow when the groundwater level rises. It is upon such water, saturating at least the lower portions of accumulations of loose material, that nearly all shallow wells depend.

In south-central Oregon the processes of soil formation have made but little progress. On the forested mountains the underlying rock is nearly everywhere in evidence, being covered in most places with only a foot or two of soil. All of the plateaus are rocky, with scarcely enough soil covering to give foothold to the scanty growth of sage. In the valleys, however, there is a fairly deep mantle of soil, an accumulation due chiefly to the contributions of small streams and to material brought by the winds from the higher plateaus. In these sands and silts is found all of the ground water that has thus far been developed in Lake County.

In many localities no definite data were to be had from which to estimate the thickness of such accumulations in the several valleys, but it is thought that in Silver Lake and Christmas Lake valleys it may reach a maximum of between 100 and 200 feet, while in some of the other basins it may be two or three times this depth.

\section{ARTESIAN CONDITIONS IN LAKE AND STREAM DEPOSITS.}

Water under sufficient pressure to bring it to the surface when properly tapped is sometimes found in old lake valleys. Streams flowing down from the surrounding slopes brought to the ancient lake alluvial material, which was assorted by the action of the lake water, the coarser being deposited first along the borders, while the finer was held longer in suspension. This assorting action of the water, causing deposition first of the sand and gravel along the margin and later of the finer sediments over these, resulted in the formation of wedgelike layers of sand and gravel, thinning out toward the center of the lake and alternating with layers of fine silts. The drying up of such a lake may leave a fertile valley, underlain by interbedded coarse and fine material, the coarser, thicker, looser beds being exposed in places along the edge of the valley, while the finer materials serve to confine percolating water to them. Thus storage reservoirs in lacustrine material are formed that will supply flowing wells sunk in the lower parts of the valley. The north end of the Colorado Desert, in southern California, is such a valley. Flowing water is obtained in it, chiefly from sand and gravel that underlies the surface at a depth of 450 to 1,000 feet. 
In southern California many of the streams are dry or nearly so during the greater part of the year, but each storm swells them to torrents that carry down quantities of material from the mountain slopes to the valleys, where it is dropped. A large share of the water also sinks in the lower slopes. This work of intermittent torrential streams has built up at the mouths of the canyons alluvial cones, which farther out in the valleys have merged together. Coarse and fine materials have thus become interbedded, and wedge-shaped masses of gravels extend into the lowlands. These are in some places underlain and overlain by finer, less pervious materials, and their bases extend far enough up the valley sides to give enough pressure to the water to bring it to the surface when wells are bored. It is from such a source that the artesian water of parts of southern California and of San Joaquin Valley is obtained.

\section{DEEPER WATER.}

\section{CONDITIONS OF OCCURRENCE.}

As distinguished from the water in the looser, unconsolidated material, there is water that circulates in the porous strata of the underlying rock masses. Typically the shallow water is limited downward by the upper surface of the bed rock upon which the sand and gravel in which it circulates are deposited, while the deeper water is to be found in this bed rock. Its occurrence here and the possibilities of its utilization for irrigation or other purposes depend upon several factors, among which the porosity of the rock is one of the most important. Sandstones, on account of their greater porosity, are the rocks in which deep water is most often found, but it may be found in any porous rock if the other requisite conditions are fulfilled.

\section{STRUCTURES.}

The structure or attitude of the rocks is also of very great importance, for upon this depend the circulation of the water, the pressure under which it may be stored, and its accessibility beneath any given area.

In regions of impervious beds alternating with porous layers that are suitably exposed, so as to allow the absorption of a part of the rainfall and snowfall, the structures most favorable to the existence of water under pressure are synclines and monoclines-that is, rocks bent into trough-shaped or saucer-shaped folds or given a general dip in one direction.

The syncline is the ideal structure for flowing wells. The water that enters the porous beds exposed along the edges of a given basin percolates downward toward the lowest portion of the basin, and, collecting there under the pressure of the water higher up in the porous strata, rises toward the surface when tapped. 
Faults, or fractures of the rocks, are unfavorable to the collection of water, because the fault planes that break the water-bearing beds furnish it an easy means of escape.

Monoclines that are limited by faults-i. e., tilted blocks-are therefore not favorable structures for deep-water storage; but monoclines that are not broken, but pass into horizontal structure, or whose individual beds thin out down the dip, often yield flowing wells. ${ }^{a}$

As has been shown under the heading "Geology," Lake County is underlain by igneous rocks, a condition that at first thought seems fatal to the existence of available deep waters, for igneous rocks are usually compact and in irregular masses, allowing little opportunity for the storage of water or for its orderly circulation, so that it may be developed for economic uses. But the most extensive masses of these Lake County rocks are basalts, which spread out in widely extended sheets over the surface, so that their distribution is much like that of stratified rocks. Accompanying the basalt flows were volumes of fragmental volcanic material. This was also distributed as thin sheets or lenticular masses by streams and by deposition in lakes, and now appears as tuff beds associated with the basalts. This material is in many places more porous than a sandstone, and where other requisite conditions exist may serve efficiently as a water-bearing stratum. The vesicular basalt is itself sometimes regarded as being capable of storing water, but its vesicles are only isolated voids in an otherwise compact rock, not connected passages as in a porous material, and hence circulation of water is practically impossible in them.

In the great scarp that forms the eastern face of Steins Mountains, Russell $^{b}$ estimated that there are from 80 to 100 layers of coarse "sandstone" interbedded with the basalts; and in the many scarps of Lake County there are layers of light-colored porous material between the individual lava flows, although they are less numerous and less extensive than in the beds farther east.

Thus far no deep borings have been made in Lake County to determine whether these porous beds, in which alone rock water in valuable quantities may be expected, exist beneath the surface, and only by such tests can their presence or absence be proved. It is believed, however, that the probabilities are strong enough to justify the drilling of test wells in a few localities.

In other parts of this great lava area, especially in southern Washington, artesian water is obtained from sediments associated with the basalt, and it may also underlie portions of Lake County.

$a$ For further discussion of artesian hasins see Water-Supply Papers No. 54, pp. 101-104; No. 78, pp. 10-14: No. 118, pp. 61-67; and Bull. No. 319 .

b Russell, I. C., Artesian basins in southwestern Idaho and southeastern Oregon: Water-Supply Paper No. 78, U. S. Geol. Survey, 1903, p. 19. 
In the Harney Basin, 130 miles east of Silver Lake, are the two following wells, which prove the existence of water under pressure beneath that valley, but for lack of proper care and casing these wells do not flow now. In 1893 a well was sunk to a depth of 848 feet about 6 miles southeast of Burns. Water was struck at 350 feet, which rose to the surface and overflowed, and at 840 feet another water-bearing bed was tapped; but in 1902 attempts to improve this well caused the flow to cease. In 1896 a 507 -foot well was drilled near Harney, which at a depth between 200 and 300 feet struck water that rose to the surface, but the well was not cased and soon stopped flowing. ${ }^{a}$

In discussing the several valleys of Lake County the structural conditions in each will be considered in some detail and the evidence in regard to the probability of securing flowing artesian water will be given.

\section{TEMPERATURES.}

In the study of underground waters the temperature offers interesting and often most suggestive evidence. It has been determined by observations in deep wells and mine shafts throughout the world that below the surface layer, about 50 feet in thickness, which is affected by daily and seasonal changes, the temperature increases at a rate of $1^{\circ} \mathrm{F}$. for each 50 or 60 feet in depth. So that when wells or springs yield warm waters and it seems likely that their temperatures are not due to exceptional conditions, like proximity to masses of rock heated by volcanic activity, or to a zone of faulting, an estimate may be made of the depth from which they rise. This can not be safely applied to waters that rise along fault zones, because the enormous friction accompanying the faulting produces high temperatures in the adjacent rocks and abnormally heats waters that rise in their vicinity.

In this respect $70^{\circ} \mathrm{F}$. is sometimes taken as the temperature above which natural waters are classed as hot, ${ }^{b}$ while between this figure and the mean annual temperature of the region they are classed as warm. Those springs whose waters are of about the mean temperature, or in winter below it, are classed as cold. This classification is a convenience only and can not be rigidly applied, because as will be at once realized, the same temperature that is called warm in northern latitudes might be classed as cool in equatorial regions, and, indeed, there are places whose mean temperature is above that of the so-called hot waters.

\footnotetext{
$a$ Russell, I. C., Artesian basins in southwestern Idaho and southeastern Oregon: Water-Supply Paper No. 78, U. S. Geol. Survey, 1903, pp. 40-41.

$b$ Peale, A. C., Natural mineral waters of the United States: Fourteenth Ann. Rept. U. S. Geol. Survey, pt. 2, 1894, p. 68.
} 


\section{THE LAKE VALLEYS.}

\section{WARNER VALLEY.}

Warner Valley is a long, narrow depression that extends from north to south in the eastern part of Lake County, and continues into California as Surprise Valley. Its northern portion is only 6 or 8 miles wide, and is bounded on each side by the steep walls that have been described under the headings of "Topography" and "Structure" (pp. 9, 25.)

In the valley bottom there is a string of partially connected alkaline lakes about which are marsh areas that represent for the most part lands from which the waters of the lakes, which are slowly shrinking, have but recently withdrawn. There is both geologic and historical evidence of this shrinkage of the lakes, which are now but remnants of the water body that covered the floor of the whole valley during Quaternary time. Faint beach lines of this former lake are still to be seen in a few places along the sides of the valley, while the litigation mentioned on page 12 is a result of minor changes in level that have taken place within the last half century.

There are but few settlers in the valley, and the agricultural development is limited to small gardens and alfalfa patches and to the harvesting of wild hay from the marsh land as winter feed for cattle and sheep.

Three streams-Warner, Honey, and Twelvemile creeks-flow into the valley from the west or southwest. From each of these a part of the water is diverted for irrigation, but as the supply is small the area thus watered is inconsiderable. These creeks bring down a certain amount of débris and deposit it at the edge of the valley. Honey Creek especially has thus built up a large alluvial fan where it debouches into the lower lands, but the greater part of this material was probably deposited as a delta in the former lake, and this delta is now being rapidly dissected.

Little or no attempt has been made to develop the shallow ground water for irrigation. Water in apparent abundance is obtained in wells only a few feet in depth, but it is used only for domestic purposes and for stock. It is possible that rather deep wells sunk at the outer edges of the alluvial fans of the streams mentioned above would yield flowing water if properly cased, but this would be only in the lower lands, where water for irrigation is of least value. The widest area of cultivable land is in the northern part of the valley, where there are no perennial streams and the region is dry and covered with sagebrush. As elsewhere in the valley, water exists within this area at shallow depths, but it is somewhat alkaline, and it is improbable that this land could be successfully farmed with such irrigation water as could be developed locally.

48133 -IRR $220-08-4$ 
The structure of Warner Valley is unfavorable to the existence of water under pressure in the porous beds of the basaltic series underlying the alluvium and lake sediments. The valley owes its origin to faulting, the southern portion being a dropped block faulted on both sides, as shown in the cross section $\mathrm{Pl}$. X, page 66 .

The scarp that limits the valley on the west dies out near Plush, so that the northern part of the valley is formed by the lower portion of a tilted block, as shown in the section through Chewaucan Marsh (Pl. X). It has been shown (p. 47) that such faulting is unfavorable to the occurrence of ground water under pressure; hence it is not worth while to undertake deep drilling in the rock underlying this valley in the hope of obtaining flowing water.

\section{GOOSE LAKE VALLEY.}

Goose Lake Valley lies in the southern end of Lake County. The lower two-thirds of the lake is in California, but by far the greater portion of the valley is in Oregon, north of the lake. On the east the steep-faced extension of the Warner Mountains borders the valley at only 2 or 3 miles' distance from the lake, but to the north and northwest the surrounding slopes are more gentle and give way to low hills on the southwestern side.

Around the north end of the lake there is marsh hay land, but the upper part of the valley is practically all unreclaimed and is used only for grazing purposes.

Nearly all of the people in this valley live on its eastern side. Lakeview, the county seat, is situated at the edge of the valley a few miler beyond the north end of the lake. Fifteen miles south of it is the town of New Pine Creek, at the Oregon-California line, and between these two towns there are a number of ranches; but on the west and the north sides of the valley there are only a few scattered homes.

Near New Pine Creek a number of orchards and gardens are irrigated by the small streams along the eastern side of the lake, and these, together with shallow wells, supply all of the water at present needed. At Lakeview a good supply of water for the town is obtained from springs in the hills above, and the few private domestic wells reach only to the ground-water level, so at no place in the valley has an attempt been made to get deeper water in the valley sediments.

At the north end of the valley gravel beds have been deposited. These are probably saturated below the ground-water level, and water could be developed by pumps, but the returns to be expected would scarcely warrant this means of irrigation, at least for some years to come.

The filling in of the valley depression by wash from the surrounding slopes, the presence of the lake, much smaller now than in the 


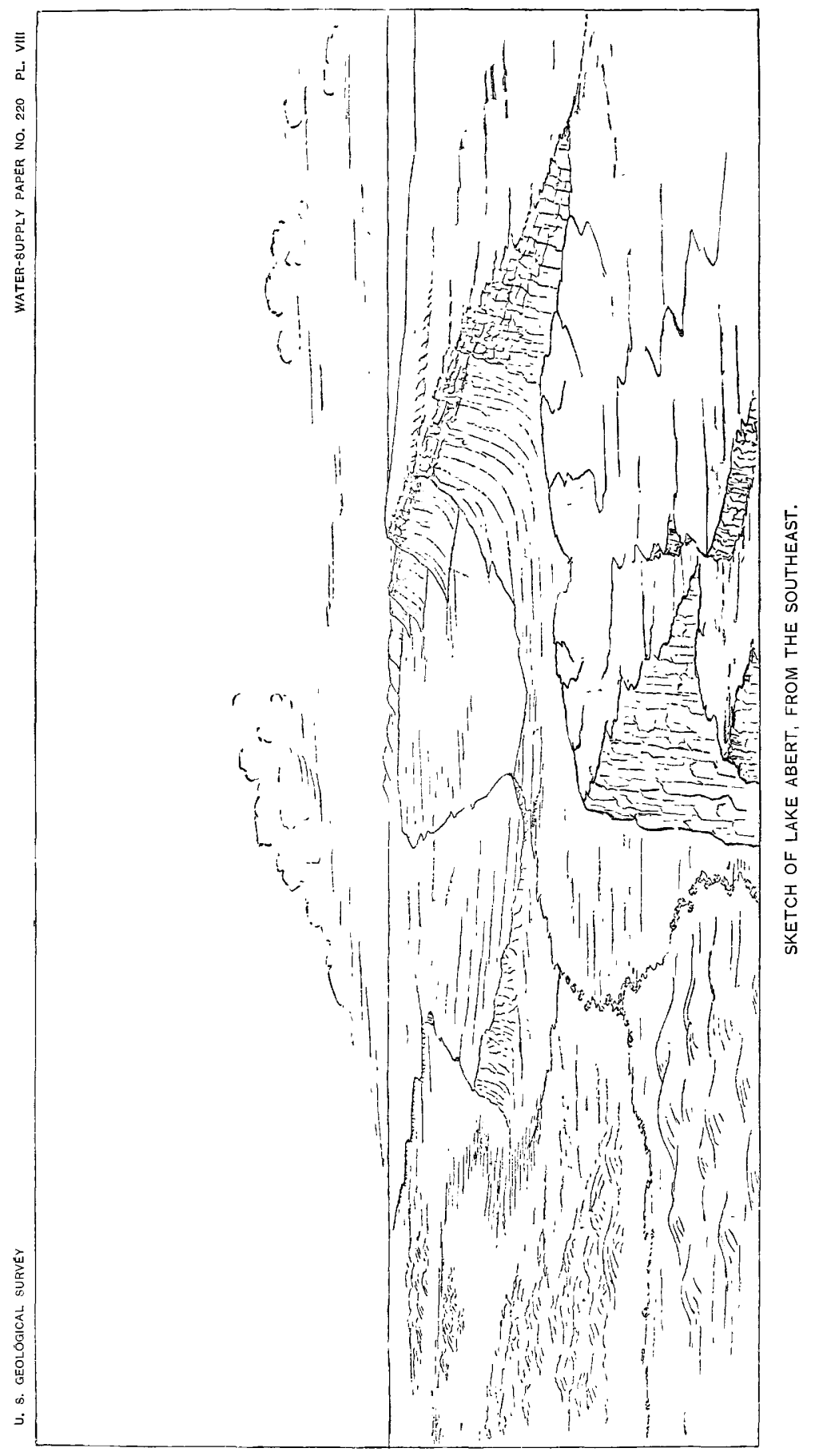



past, and the constant deposition of fine sediments in this lake are genetic conditions favorable to that alternation of coarse and fine deposits essential to artesian flows. It is probable that cased wells of the California type (described on p. 78) and less than 500 feet deep, if sunk in the lowest parts of the valley, west of Lakeview, would yield flowing water; but it is not thought that such water can be developed in the higher, northern part of this valley.

On the eastern edge of the valley, near Lakeview, three hot springs ise, with a temperature of about $173^{\circ} \mathrm{F}$. These serve to strengthen the topographic evidence that this, like Warner Valley, has been produced by a faulted block, having the character of the dropped keystone of an anticlinal arch, as shown in the cross section on Pl. X. In such a structural basin, whose origin is almost fatal to the existence of rock water under artesian head, it would be useless to attempt to obtain flowing wells by deep drilling if ever water should be needed for agricultural purposes.

\section{ABERT LAKE BASIN.}

In the central part of the county Summer Lake, Chewaucan Marsh, and Abert Lake are in a valley that was once occupied by a single great water body; hence these three now rather distinct basins are topographically one. Structurally, however, they are separate, and therefore they will be separately considered.

Abert Lake lies in the eastern, lowest depression of this valley, in the most typical structural basin formed by a tilted block in this entire region. On its eastern side a cliff rises from the water's edge to a height of more than 2,000 feet, while on the western side the gentle slope of the surface of the tilted block rises to the scarp overlooking Chewaucan Marsh, as is shown in Pl. VIII, reproduced from Russell's article on the region.

As its water level has lowered, the lake has left an extended area of marsh land at its northern end, but little or none along the steeper sides of its basin. This marsh land is controlled by the "X L" ranch, and is used for winter pasture, besides furnishing many tons of wild hay.

A strong spring of good water, $63^{\circ} \mathrm{F}$. in temperature, rises at the ranch house and supplies abundant water for stock and for all domestic purposes.

In the northeastern portion of this basin there is some agricultural land where one or two families live, but little attempt has been made to develop water for irrigation. At a number of places along the western shore of the lake there are fresh-water springs of small volume. These are evidently fed by waters that accumulate on the monoclinal slopes between the lake and Chewaucan Marsh, seep down the dip of the basalts, and reach the surface at the lake border. 
As there is so little land here possible of reclamation, and hence s. little demand for a large water supply, and as, in addition, the geologi structure is so evidently unfavorable, it is scarcely necessary to sa: that the probability of the occurrence of available rock water unde artesian head is very small.

\section{SMALLER VALLEYS.}

Near the head of Crooked Creek, about 12 miles south of Lake Abert in a narrow valley known as Antelope Valley, there are a few settlers The alluvial soil here seems deep and is capable of growing good crops but as elsewhere, and under present conditions perhaps most profit ably, the land is used mainly as pasture.

Along Coyote and Moss creeks there are also a few settlers, where th streams supply water for small gardens and orchards, and nearly a] such small areas have long been occupied by homesteaders.

\section{VALLEY OF CHEWAUCAN MARSH.}

The valley occupied in large part by Chewaucan Marsh extend southeastward from where the river of the same name emerges fron its canyon to within a short distance of Lake Abert. Its eastern borde is the edge of the tilted block that dips under Lake Abert, while th western side is bounded by the steep slopes that separate it from th drainage basin of the river.

Paisley is situated on the banks of the river where it enters the val ley. South of Paisley, along the edge of the valley, there are severa ranches where grain, alfalfa, and fruits are grown, but north of th town there are no settlements.

The marsh land is under the control of two or three large cattle com panies. The river water mostly sinks in this marsh, but by means $a$ drainage canals the land is kept fairly dry, so that great quantities o wild hay are cut from it: Only at The Narrows is there much unpro ductive alkaline land.

An area of several square miles north of Paisley and the terrace south of the town, against the hills, are covered with gravel brough down by Chewaucan River. A section in this material is exposed a the river bank, just below the Paisley bridge, showing about 4 feet a this gravel overlying 6 or 8 feet of river sands, which in turn overli finer material, probably lake sediments. A low alluvial divide sepa rates the marsh from Summer Lake Valley, but a well-defined channe still exists in it, through which the two basins were formerly connected

On the terrace land near Paisley a number of acres of alfalfa ar irrigated by ditches that take water from the river a short distanc up its canyon. Much land above the level of the present irrigatin: ditches, at both the northern and the southern ends of the marsh an along the western side of the valley, will be susceptible of cultivation 
hen water can be supplied to it, but at present it is used only for tock range. The greater diversion of the waters of Chewaucan River or this purpose would no doubt benefit the marsh land also, for much $f$ it is too wet to permit easy harvesting of the wild hay. While it is robable that water for irrigating these higher parts of the valley can est be obtained from storage reservoirs in the upper course of the iver, a number of small streams along the western side of the valley ould be made to furnish a useful local supply. These streams usually ink in the alluvial fans at the mouths of their gorges, but when traced oward their sources in springs in the mountains above are found to ave a considerable flow, which might profitably be piped or flumed to he lands along the edges of the valley.

Like most of the other valleys, that occupied by Chewaucan Marsh as been produced by faulting. The scarp on its eastern side is clear vidence of such movement there, and it is thought that similar eformation has taken place on the western side also, as shown in he cross section, $\mathrm{Pl}$. $\mathrm{X}$, but the evidence on this side of the valley not so clear.

This structure of course precludes the probability of the existence of vailable water in the underlying rocks. But in the central part of ne basin there is too great an abundance of surface water, the prob$m$ at present being rather one of regulation of the supply and of rainage than of the development of additional water; and, as heretore stated, for irrigating the arid portions of the valley water can robably be best obtained from the river.

\section{SUMMER LAKE VALLEY.}

\section{DESCRIPTION.}

Summer Lake Valley resembles the basin of Abert Lake in being ounded on one side by a great scarp and on the other by more gentle opes. On the north rise the slopes of the cross anticline separating from Christmas Lake Valley, while southward the delta deposits of hewaucan River divide it from the marsh lands of the river's lower ourse. The land between the south end of Summer Lake and Paisley gravelly and is apparently not alkaline. At present it is too arid be of value for agriculture, but by irrigation it can no doubt be endered very productive.

\section{STREAMS.}

Along its western side, between the rim rock and the lake's edge, umerous streams furnish water for irrigation as well as for domestic urposes, and it is here that most of the ranches of this valley are tuated. This is one of the mildest spots in the county, so that early all the common vegetables and many varieties of fruit are to be 
found in its gardens and orchards; but the tillable land is limited to the narrow strip between the lake and Winter Ridge; hence its area is not great. In the northern part of the valley much of the surface is either arid, sandy, sagebrush land, or a greasewood flat. Near the lake the land is more moist, and here a few settlers have taken up claims, but most of the marsh land is controlled by stockmen.

SPRINGS.

Conditions of occurrence.-The largest and best known springs in this region are those that issue through the sediments near the northwest edge of the valley and give rise to Ana River, which flows southward about 5 miles, to Summer Lake. Near these springs the river channel has cut nearly 40 feet deep into the lake deposits, prohibiting easy utilization of its water, but farther down a small part is diverted for irrigation.

The marshy areas around the northern end of the lake are kept moist by numerous springs, some of which form only small marshy spots, while others give rise to streams, such as Buckhorn and Johnson creeks. The temperature of Buckhorn Creek was not measured, but it is said to be somewhat warmer than that of Ana River $\left(66^{\circ} \mathrm{F}\right.$.), while that of the two springs supplying Johnson Creek is 10 degrees cooler, or $56^{\circ} \mathrm{F}$.

At the Bonham ranch, on the eastern side of the valley, the temperature of the strongest flowing spring is $66^{\circ} \mathrm{F}$., the same as that of the springs that supply Ana River. On this ranch, in what is known as Thousand Spring Valley, a number of acres are irrigated naturally by many small springs. By distributing the water through small ditches Mr. J. H. Bonham has reclaimed much of the greasewood flat on his ranch and has greatly increased the original area of marsh hay land, thus demonstrating what water alone will accomplish on these apparent wastes. The water, constantly rising and evaporating tends to increase the alkalinity of the soil, and is insufficient in quantity to permit drainage and the leaching out of the alkali, so that only the natural grasses and salt bushes grow readily. Of the many kinds of trees tried, only a few cottonwoods along one of the ditches have lived.

The tendency of the alkali to rise with the use of water is alsa shown on the ranches in the northwestern part of this valley, near Ana River. Cultivation and irrigation from shallow wells tapping only the ground water have in several instances caused the garden areas to become so alkaline as to prevent nearly all of the common vegetables from maturing.

At the morth end of the valley, in JuniperCanyon, water rises, apparently from a canyon spring or one where water seeps out of a tufa bed exposed along the canyon side. This has only a small flow, and 
it is improbable that any considerable amount could be developed here to irrigate the higher valley sides, but as it is the only spring of this character noted it is thought worthy of mention.

At the southeast end of Summer Lake the Woodward hot spring rises, with a temperature of $123^{\circ} \mathrm{F}$. The flow in November, 1906, was about 2 miner's inches. The water is used for irrigating garden vegetables and for bathing purposes. The location of the spring is not far from the steep slopes of this side of the valley, and the occurrence is considered additional evidence of faulting here.

Origin of the Ana River springs.--There are additions to the flow of Ana River, probably by seepage along its banks, below the group of five or more large springs at its source that supply the greater part of its flow. Johnson Creek, east of Ana River, has a flow of perhaps 20 second-feet, and the springs of Thousand Spring Valley yield a large aggregate. All told, it is probable that at least 200 second-feet constant flow rises through the silts and alluvium in this end of Summer Lake Valley.

The question of the source of this water is one that interests all who visit the springs. The region is semiarid, and the drainage area tributary to Summer Lake is limited and clearly inadequate to supply the water yielded by the strong and remarkably uniform flow of the springs. It has been asserted that Silver Lake is the source of supply, but in the years when this lake dried away completely the flow from the springs did not appreciably lessen.

No large streams discharge directly into the Summer Lake basin, but Chewaucan River discharges into the same topographic depression just south of the alluvial divide that separates that basin from Chewaucan Marsh. It has been suggested that water from this stream, which sinks in the sands and gravels, may percolate northward through the porous material that fills the lake basin and, rising beyond the lake, supply the springs in question. But the total mean flow of Chewaucan River during 1906, a year of more than average precipitation, was only 189 second-feet, and the flow during the previous year, of less than average precipitation, was only 93.5 second-feet. The total average discharge of this stream then, is less than the yield of the springs; and much the greater part of this total flows out through Chewaucan Marsh to Lake Abert. The relative elevations of the Ana River springs and the mouth of Chewaucan Canyon are not known. If the springs shall eventually be found higher than the canyon mouth, this fact will at once prove definitely that Chewaucan River water can not be the source from which the springs are supplied. The evidence just given, however, is regarded as practically conclusive, but additional evidence in support of this conclusion is supplied by the temperature of the water of the Ana River springs. This issues at $66^{\circ} \mathrm{F}$., which, if the usual increment of $1^{\circ}$ above the mean annual temperature for each 50 or 60 feet in depth be accepted, indicates that the 
water rises from more than 1,000 feet below the surface. It seems unlikely that the alluvium is this deep near the north rim of the valley, where the springs issue, hence it probably rises from porous beds in the underlying basalt.

The fault that separates Winter Ridge from the valley east of it, since it represents a fracturing of the beds, furnishes a passage upward for any water that may be circulating at depths in porous layers interbedded with the basalts. It is unlikely that this water comes from the eastward, because the known faults in that direction furnish drainage ways through which any confined water can escape, and the intermediate areas are arid.

West and southwest from Summer Lake, however, the topography does not indicate such faulting as is characteristic of the area eastward; it is indicative rather of open folding. Since much of this region is mountainous and timbered and receives a relatively high precipitation, as is indicated by the fact that it is the gathering ground for such large streams as Sprague and Williamson rivers, it seems a competent source of supply even for such large-springs as those in question. If the open folding that is indicated exists here, it provides for the exposure of the porous beds in the lavas, so that the water supplied by precipitation may enter them. This folding may also provide sufficient head to force the water eastward up the Winter Ridge monocline into Summer Lake Valley.

Another explanation, which differs slightly from that just given, has been offered. The Summer Lake basin is considered to be a collapsed anticline - a block of the earth's surface that has dropped as a result of the stresses to which the crust has been subjected, and has broken away from the rocks on each side, which are now exposed as the scarps north and west of Summer Lake. It may be that the water of the Ana River springs and the other large springs nearby percolate northward from the region of the upper Chewaucan drainage basin, along the axis of this anticline, and escape to the surface through the faults that mark both the northern edge of the dropped block and the northern edge of Summer Lake Valley.

In both of these explanations the spring waters are regarded as waters that escape from the basalts through the passages that the faults provide. They differ in the assumed source and direction of percolation of these waters. Of the two, that which supposes that they originate in the country west and southwest of Summer Lake is regarded as the more probable.

\section{ARTESIAN POSSIBILITIES.}

Shallow water.-The evident saturation of the alluvial and lacustrine deposits over wide areas in the northern end of Summer Lake Valley by water that seeps to the surface or that rises in definite springs suggests the possibility of obtaining flowing water in this 
locality by sinking relatively shallow cased wells from 100 to 500 feet in depth. These swampy conditions in areas of marked slope are familiar evidences of the existence of subsurface water under pressure sufficient for the development of flowing wells, and so strong is this evidence in certain parts of this valley that there can be but little loubt that the sinking of cased wells would prove a successful venture.

Whatever the origin of the water in the unconsolidated deposits, it is clearly present in some quantity. As it now rises naturally by seepage over wide areas, it is very harmful to the land, depositing as it evaporates great quantities of alkali, which unfits the soil for agricultural purposes. Wells sunk in the moist land should therefore bring about two beneficial results: First, the present numerous small springs would probably dry up, their yield being concentrated in the relatively few wells, so that it would be much more readily available for irrigation; and secondly, the drying up of these seepages would lessen the present rapid rise of alkali and would thereby render the present alkaline lands valuable. Thus the sinking of shallow artesian wells should accomplish both concentration of the water supply and drainage of the swampy land. Thousand Spring Valley and the basins of Buckhorn and Johnson creeks are favorable localities for experimental wells.

Deep water.-In the paragraphs on structure (p. 26) and on the origin of the Ana River springs (p. 55) it has been explained that Summer Lake Valley is probably due to the collapse of an anticline and the consequent dropping down of a great block of the basalts. The bed rock beneath the valley is therefore faulted, and whatever water may be circulating through it is not confined under pressure; but is permitted to leak out along the fault planes into the overlying alluvium. As already indicated, the water yielded by the great springs of this area probably has this origin. But this leakage is a condition unfavorable to the existence of water under pressure in the basaltic rock underlying the sands, gravels, and silts that make up the surface of the valley. It is not expected, therefore, that deep drilling would develop flowing water in the bed rock beneath the valley.

\section{SILVER LAKE VALLEY.}

Northwest of Summer Lake Valley, and separated from it by a divide about 500 feet in height, lies Silver Lake, in the southern end of its basin. The lake itself is bounded on the east and on the west by scarps, but northward the valley opens out into a wide area of marsh, beyond whose borders there is much nearly level sagebrush land, at present dry, but cultivable and valuable if water can be applied. From the gentle slopes to the west and southwest three streams, Silver, Bridge, and Bear creeks, more definitely described on pages 31 and 35, flow into Pauline Marsh and thence into the lake. On the north 
and east Conley Hills and their southward extension separate the valley from the larger Christmas Lake Valley. Topographically, however, Silver Lake Valley is really a part of this wider area, being connected with it by a broad, low passage extending eastward to Thorn Lake, into which, at periods of very high water, Silver Lake overflows.

Like other areas of similar character, Pauline Marsh is given over to the growth of native grasses that are cut for hay, while drainage ditches carry off much of the superfluous water southward to the lake. The sagebrush land beyond the limits of the marsh can be made productive by irrigation, but at present it is used mainly as a stock range. Only from Bear Creek is water diverted to any extent for irrigation, and this is used only in the extreme western part of the valley.

On the low slopes of the south side of the valley a few springs have produced green patches of pasture land and furnish watering places for the range animals. The largest of these, Thomson and Murdock springs, 3 miles sou theast of Silver Lake, flowed about 9 and 25 miner's inches, respectively, in October, 1906. Their temperature $\left(48^{\circ}\right)$ indicates that they are surface springs, not deep seated, though the water may rise from a porous bed along which it has percolated from the slopes of Hager Mountain.

At the town of Silver Lake water is obtained in the 25 or 30 domestic wells in a soft porous material, usually at less than 30 feet below the surface. This seems essentially a subsurface flow, depending for its supply on the run-off from the surrounding slopes, for in winter, when the mountains are snow covered and the ground is frozen, the water level in the wells lowers. The water is of good quality, tests indicating only about 50 parts of alkaline salts in 100,000 .

The only attempt to obtain deep water in the area examined has been made at Silver Lake. Mr. F. M. Chrisman, of this place, put down a 6-inch hole on the south edge of the town to a depth of about 250 feet, where the drill became caught and work was suspended. The usual subsurface water was found at a depth of $47 \mathrm{feet}$, but no other supply was developed, the drill being fast in dry vesicular basalt. A record of the well as kept by Mr. Chrisman shows a depth of 108 feet of clays, sands, and gravels, below which lies a thick tuff bed, probably like that at Fort Rock, underlain by basalt.

The structure of this basin seems more favorable to the finding of artesian water in the basalts than that of any of the other valleys of Lake County, except perhaps the Christmas Lake desert. On the west and south the slope of the lava beds is toward the valley. To the north also, along the base of Horning Bend, an exposure of tuff indicates that the dip is toward the valley, but on the eastern side this structure is not exhibited. The tuff composing these eastern hills is somewhat folded, but the dips are universally eastward, away from 


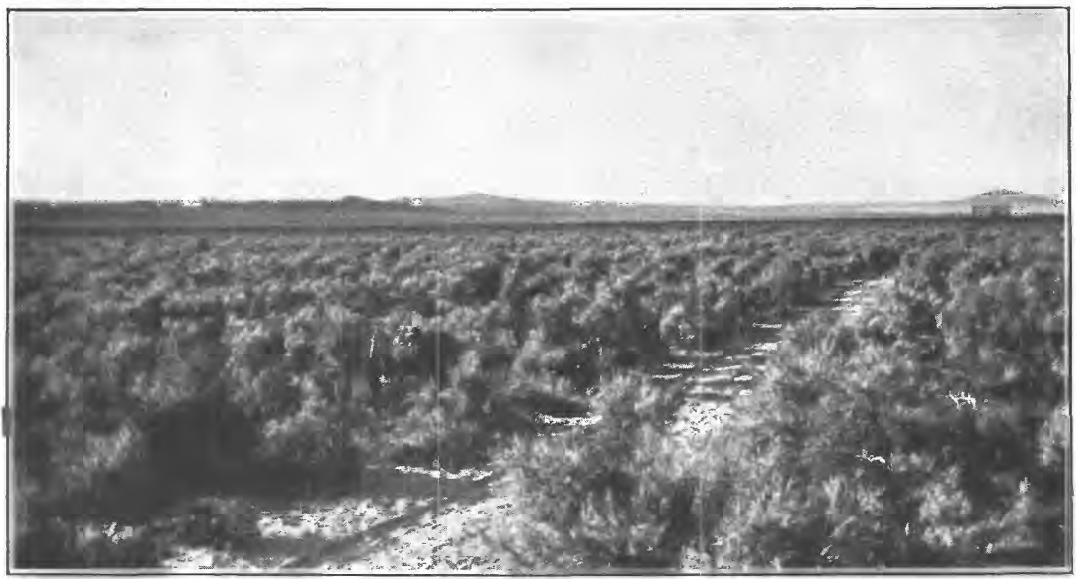

A. SAGEBRUSH IN CHRISTMAS LAKE VALLEY.

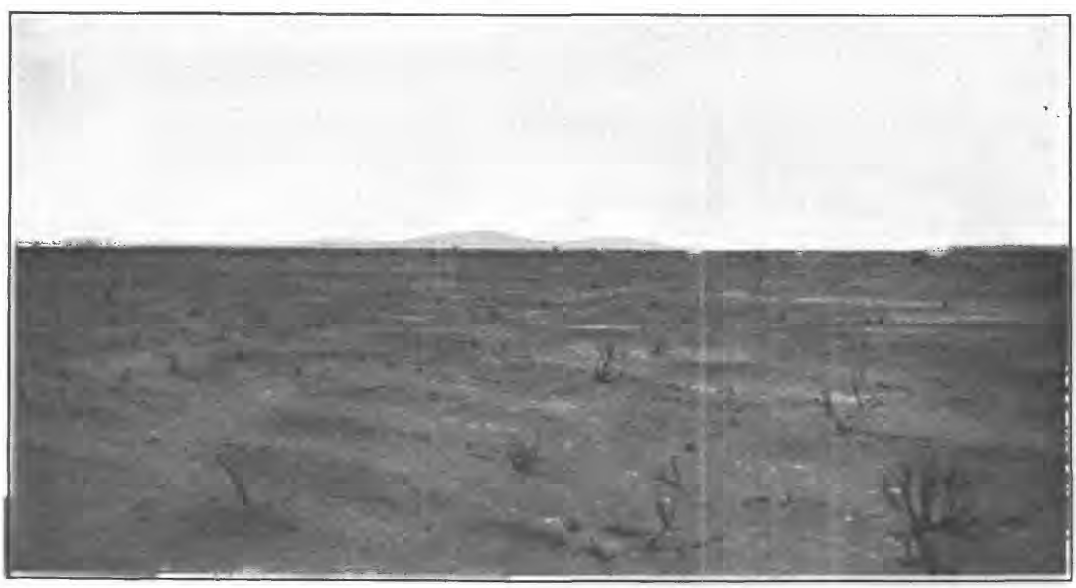

B. AREA IN CHRISTMAS LAKE VALLEY CLEARED BY BURNING.

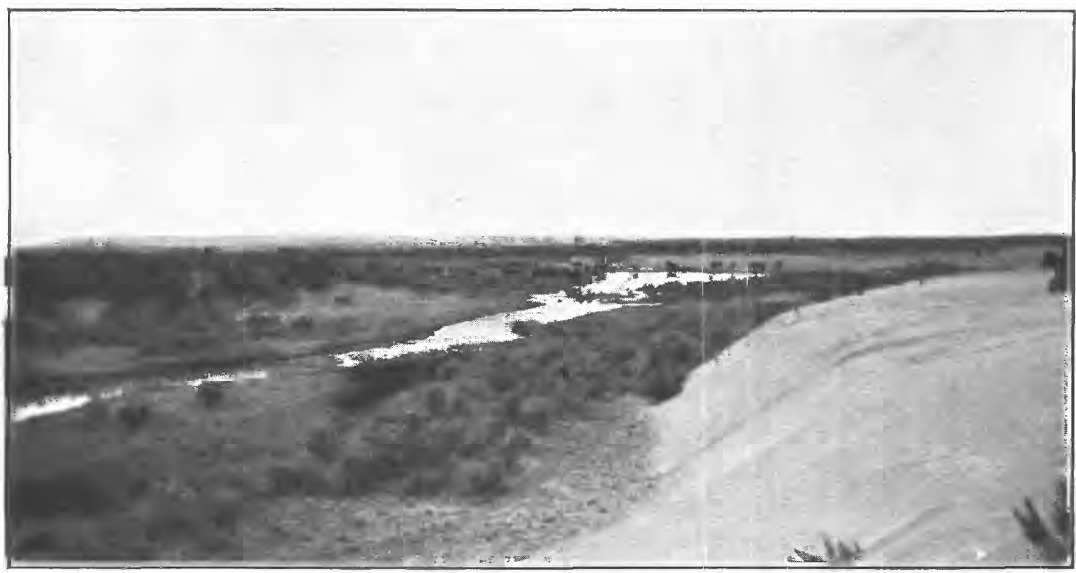

C. SAND SPRINGS. 

Silver Lake Valley. What effect on artesian conditions this structure may have can not be stated definitely, but the Conley Hills and their extension in each direction probably separate it structurally from that of Christmas Lake Valley. Certainly the structural conditions are such as to justify a thorough test by the drilling of a well, 1,000 to 2,000 feet in depth, in the neighborhood of Silver Lake.

Satisfactory evidence of the structural relation of the Conley Hills to the regularly dipping basalts south and west of them, or to the horizontal basalts across the desert on the northeast, was not obtained, but the geologic cross section $(\mathrm{Pl} . \mathrm{X})$ is thought to represent the essential features of their relation to the valley on each side at its southern end.

\section{CHRISTMAS LAKE VALLEY.}

\section{DESCRIPTION.}

The largest valley of the Lake County area, and the one that seems capable of the greatest development, is that of Christmas Lake. Under this name is included all of the country northwest toward Fort Rock, as well as that around Christmas and Fossil lakes. It is an extensive, nearly level plain, 40 or 50 miles long from east to west, but much narrower from north to south. Unlike nearly all of the other valleys, it is not inclosed by steep walls; on all sides the slope to the surrounding basaltic "high desert" areas is gentle. On the west Fort Rock and Table Rock are prominent landmarks from nearly all parts of the valley, as is St. Patrick Mountain on the south, while on the north side of the valley the recent volcanic cones produce a low relief. Within the valley itself two low ridges rise above the sediments-a basaltic tongue extending southward from Bunchgrass Butte, and Sevenmile Ridge, a remnant of tuff like that at Fort Rock, that extends into the valley from its southern border.

Most of the valley floor supports a growth of sage, which in the more sandy areas is tall and dense, as in Pl. IX, $A$, but over much of the valley is not so thick as to interfere seriously with travel in any direction. In the more alkaline areas the surface tends to bake to a hardpan, over which there is only a scanty growth of grease brush.

Bunch grass and rye grass grow to some extent through nearly all of the valley land, and afford fair range for stock.

\section{SETTLEMENT.}

Two years ago there was only one family living in Christmas Lake Valley. In February, 1905, a party of a dozen or more men, neighbors and residents in Willamette Valley, were brought in by a "locator" and took up claims in the region north of Fossil Lake, now 
locally known as "Sucker Flat." In the fall of the same year and in the spring of 1906 others came in and settled, chiefly around Christmas and Fossil lakes. Post-offices have been established at

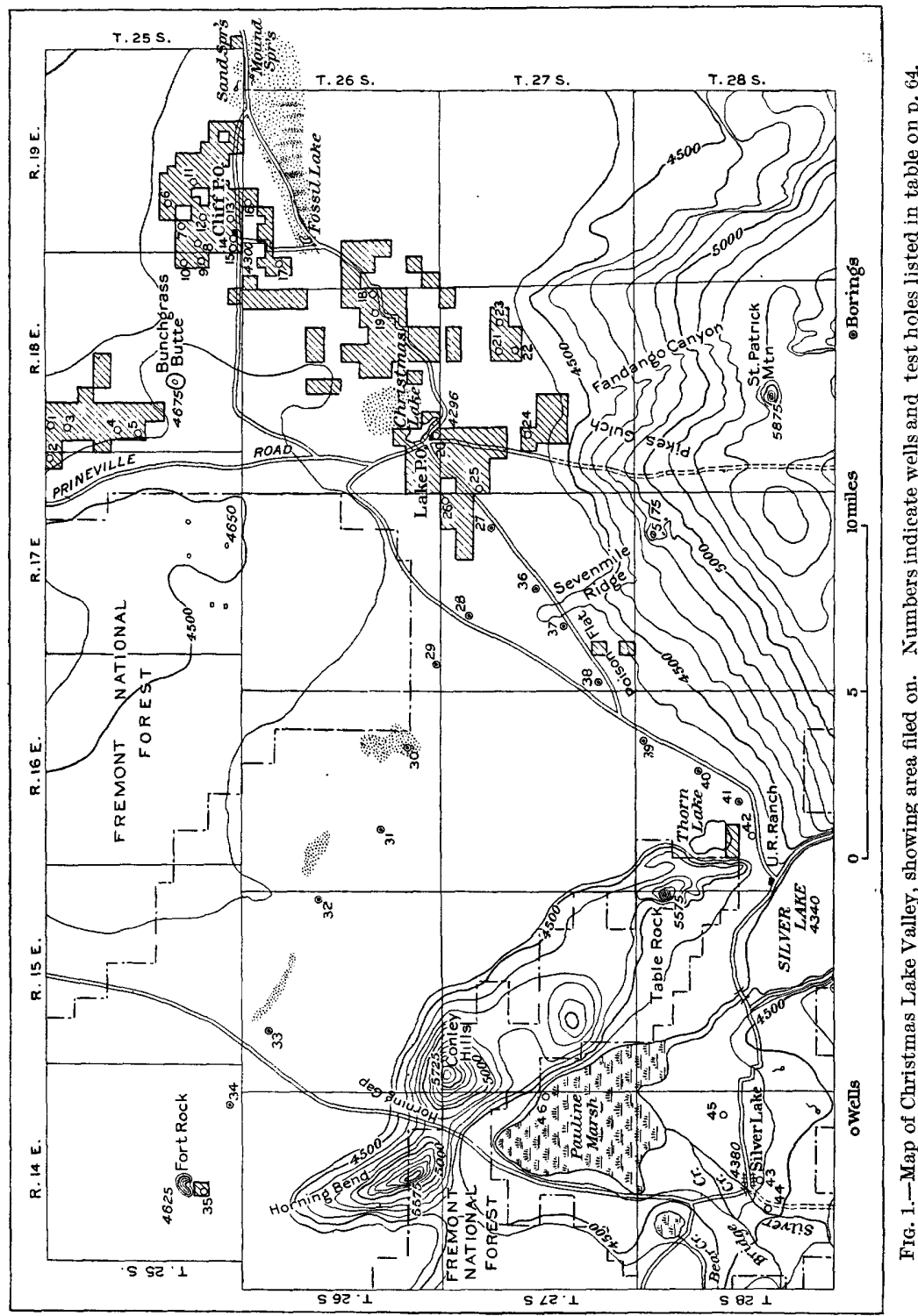

Lake and Cliff (named after the locator who brought the settlers in), and a school district has been formed. Nearly all of the claims have been inclosed by substantial barbed-wire fences, the junipers of the 
valley sides furnishing good posts for this purpose, and frame buildings have been put up.

About 120 claims had been filed on in the valley up to November 20, 1906. A number took up homesteads; others filed on desert claims. The approximate area filed on is shown in fig. 1.

\section{METHODS OF CLEARING AND FARMING.}

As most of the settlers began to clear land too late in the fall of 1905 to permit of burning, nearly all of the area planted the following spring was cleared by grubbing. Owing to the loose nature of the soil this is comparatively easy and gives a field nearly free from brush roots. During the summer of 1906 it was found that on a hot day, with a steady, moderate breeze, the denser patches of sage, once firel, burned completely, the fire often following the roots below the surface. In Pl. IX, $B$, is shown a burned area that was formerly covered with tall brush, like that in $\mathrm{Pl}$. IX, $A$, which shows a view of the tallest, densest sage in the valley, on the sandy land 2 or 3 miles west of Christmas Lake. Dragging with a heavy beam has been tried where the brush is too thin to burn readily, but it is not brittle enough to make this method of clearing successful. Grubbing seems the most practical means on such areas.

Some of the homesteaders have filed on claims, intending to rely on diry farming with constant cultivation, as practiced in Kansas and elsewhere. Most of the grain and vegetables raised during the summer of 1906 (the first season that farming was tried here) matured without irrigation, and showed that the soil is fertile, though as yet rather deficient in humus, or vegetable mold. But 1906 is generally regarded as a favorable year. As indicated by the rainfall records, it was at least as wet as the average, and in drier years such excellent results can not be expected without irrigation.

Records from places of low rainfall show that there are more seasons with less than the average precipitation than there are wet years, for in a wet year there may be twice the average rainfall or more, to balance which would require a year of absolutely no rainfall. As this almost never occurs, a few very wet years serve to keep the average up, hence in arid regions there are more dry years than wet ones.

\section{TENTATIVE IRRIGATION METHODS.}

Desert claims.-The desert land acts of 1877 and 1891 provide that a maximum of 320 acres of land may be filed on as a desert claim, but within three years one-eighth of it must be under cultivation, and the whole area under irrigation, except high places evidently not 
susceptible of irrigation; ${ }^{a}$ so that those who have filed on desert claims in this valley realize that they must develop a large supply of water within the next few years.

Pumping.-Pumping has been considered, both by windmills and by distillate engines, from a number of shallow wells, or from large basins scooped out in the soil to ground-water level; for water is found at a shallow depth all through the valley, although not in great abundance nor of good quality. From local observation of the wind during the season of 1906 the writer believes that windmills can not be relied upon to any extent to furnish power, for, as in many other arid sections, during the hot, dry periods there is little or no breeze.

Even if a sufficient flow of ground water can be developed, which from the meager evidence at hand seems doubtful, the present cost of hauling in fuel is not warranted by the returns that may reasonably be expected from the land irrigated. The quality of the subsurface water should also be taken into account in considering its prospective use for irrigation, for it is all alkaline, at least all of the shallower water, which is all that has so far been developed, and although perhaps its use for the first few years would not be noticeably injurious to crops, its continued use, if not carefully managed, could not fail to be.

Storage reservoirs.-In other parts of the Northwest small storage reservoirs are constructed to conserve the run-off of the stormy season, both for irrigation and to furnish water for stock during the summer. The methods of constructing these reservoirs and the pre-

a Section 1 of the desert land laws, approved March 3, 1877, provides that any citizen of the United States, or person who has filed his declaration to become such, upon payment of 25 cents an acre may file a declaration that he intends to reclaim a tract of desert land, by conducting water upon it within the period of three years.

Section 2 designates "that all lands exclusive of timber lands and mineral lands which will not, without irrigation, produce some agricultural crop, shall he deemed desert lands."

Section 3 provides that this act shall apply only to California, Oregon, Nevada, Washington, Idaho, Montana, Utah, Wyoming, Arizona, New Mexico, North and South Dakota.

Sections 4, 5, 6, 7, and 8, approved March 3,1891, further provide as follows: Section 4 provides that at the time of filing his declaration the party shall also file a map showing the mode of contemplated irrigation; section 5, that no land shall he patented under this act until at least $\$ 3$ for each acre of the whole tract reclaimed shall have been expended in the necessary irrigation, reclamation, and cultivation. The party must file during each year, with the register, proof that the full sum of $w 1$ an acre has been thus expended; and "If any party who has made such application shall fail during any year to file the testimony aforesaid, the lands shall revert to the United States, and the twenty-five cents advanced payment shall he forfeited to the United States, and the entry shall be cancelled. Nothing herein contained shall prevent a claimant from making his final entry and receiving his patent at an earlier date than hereinhefore prescrilied, providet that he then makes the required proof of reclamation to the aggregate extent of three dollars per arre: Procided. That proof he further required of the cultivation of one-eighth of the land."

Section 6 provides that these later sections shan not conflict with any provisions of the act of March 3,1877 .

Section 7 provides that not more than 320 acres may be filed on under this act.

Section 8 states that this act shall apply also to the State of Colorado: and that "no person shall he entitled to make entry of desert land except he be a resident citizen of the State or Territory in which the land sought to he entered is located." 
cautions that should be taken to insure their permanence are described in a recent bulletin of the Department of Agriculture. ${ }^{a}$

It seems that such reservoirs might prove of value in at least two localities on the edge of Christmas Lake Valley-in the slopes toward the sink of Peter Creek, and south of Christmas Lake, in Fandango Canyon. It is said that at times considerable flood water comes down these slopes, and even during the very general examination of the localities upon which this report is based several favorable reservoir sites were noticed.

In regard to the amount of water that could be thus stored little can be said, for data both as to the extent of the drainage areas and as to the amount of run-off are almost wholly lacking. The latter would no doubt vary between wide limits for different years, and probably a dependable supply could not be counted on to be thus stored for summer use; but this method of conserving water is used successfully elsewhere in the Northwest, and is at least worthy of consideration by settlers in northern Lake County.

In Wyoming and Dakota series of such reservoirs have been constructed in the prairies solely to provide water holes along the trails over which cattle are driven to shipping points. The scarcity of water holes in the high desert area between Christmas and Alkali lake valleys, after the natural sinks have dried up, has been the great drawback to this area as stock range. Low dams built with a comparatively small amount of labor across the lower ends of some of these sinks would greatly increase their storage capacity and the length of time they would serve as water holes, but it is doubtful if such watering places would last all summer. Even the deepest of these sinks were dry in September and October, and evidently had been so for two or three months. It is probable that in this area of indefinite drainage the run-off is so small a percentage of the precipitation, and the tributary drainage areas are so small, that such a means of conserving water for range animals would serve only to lengthen somewhat the high desert range period, but would not extend it throughout the summer. Thus it would be but a temporary expedient.

\section{GROUND-WATER LEVEL.}

In order to supplement the data concerning the ground-water level that were obtained from the shallow wells that have been dug, a number of 2-inch auger holes were put down in the unsettled portions of the valley. The locations of these test holes and of the wells examined are shown in fig. 1, and a table of the depths and water levels is given below.

\footnotetext{
a Herrman, F. C., Small reservoirs in Wyoming, Montana, and South Dakota: Bull. 179, Office of Experiment Stations, U. S. Dept. Agriculture, 1907. This bulletin may be obtained free of charge by request to Dr. A. C. True, Director, Office of Exp. Stations, U. S. Dept. Agriculture, W ashington, D. C.
} 
Wells and test holes in Christmas and Silver Lake valleys.

\begin{tabular}{|c|c|c|c|c|c|c|c|}
\hline \multirow{2}{*}{$\begin{array}{l}\text { No. of } \\
\text { well. } a\end{array}$} & \multirow{2}{*}{ Owner. } & \multicolumn{3}{|c|}{ Location. } & \multirow{2}{*}{$\begin{array}{c}\text { Depth } \\
\text { in feet. }\end{array}$} & \multirow{2}{*}{$\begin{array}{c}\text { To } \\
\text { water } \\
\text { in feet. }\end{array}$} & \multirow{2}{*}{ Material passed through. } \\
\hline & & T. S. & R. E. & Sec. & & & \\
\hline 1 & Mr. Beard. & 25 & 18 & 6 & 22 & 20 & Lake silts. \\
\hline $\begin{array}{l}1 \\
2\end{array}$ & (Test well) & 25 & 17 & 1 & 30 & (?) 29 & Lake silts (water not used). \\
\hline 3 & Mr. Gaskell. & 25 & 18 & 6 & 28 & 25 & Lake sllts. \\
\hline 4 & J. W. Hanley. & 25 & 18 & & 35 & 25 & Do. \\
\hline 5 & Mr. Beard, sr. & 25 & 18 & & 25 & Dry. & $0-18$, silts; $18-25$, rotten basalt. \\
\hline 6 & Mr. Whitney. & 25 & 19 & & 12 & 11 & $\begin{array}{l}\text { Lake silts; a little rotten basalt at } \\
\text { hottom. }\end{array}$ \\
\hline 7 & Dr. Ewing . & 25 & 19 & & 10 & 9 & $0-6$, silts; $6-10$, rotten basalt. \\
\hline 8 & Dr. Thayer. & 25 & 19 & & $12 \frac{1}{2}$ & 10 & Lake silts. \\
\hline 9 & Joe Kasperone & 25 & 18 & 25 & $12 \frac{1}{2}$ & 11 & $\begin{array}{l}\text { Lake silts; a little rotten basalt at } \\
\text { bottom. }\end{array}$ \\
\hline 10 & Frank Polte. & $2 \tilde{5}$ & 18 & 25 & 4 & Dry. & $0-1 \frac{1}{2}$, silts; $1 \frac{1}{2}-4$, rotten basalt. \\
\hline 11 & Mr. Wardall. & 25 & 19 & 28 & $13 \frac{1}{2}$ & 12 & Lake silts. \\
\hline 12 & James Wilson. & 25 & 19 & 29 & $12^{12}$ & 8 & Do. \\
\hline 13 & $\left\{\begin{array}{l}\text { James McCurdy ( } 3 \\
\text { wells). }\end{array}\right.$ & 25 & 19 & 32 & $\begin{array}{l}16 \\
14 \\
12\end{array}$ & $\begin{array}{l}10 \\
10 \\
10\end{array}$ & $\begin{array}{l}\text { 0-4, silts; remaining depth, sand with } \\
\text { streaks of clay. }\end{array}$ \\
\hline 14 & John C. Green. & 25 & 19 & 31 & 12 & 10 & Lake silts. \\
\hline 15 & W. A. MeHarg & 25 & 19 & 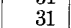 & 13 & 11 & Do. \\
\hline 16 & Mr. MeCurdy. & 26 & 19 & & 17 & 15 & Do. \\
\hline 17 & Mr. Brown. & 26 & 19 & & $11 \frac{1}{2}$ & 9 & Lake silts; a little basalt at bottom. \\
\hline 18 & Mr. Lanning. & 26 & 18 & & 26 & $24 \frac{1}{2}$ & Lake silts. \\
\hline 19 & M. W. Richmond... & 26 & 18 & & 31 & 25 & Do. \\
\hline 20 & A. W. Long... & 26 & 18 & & 22 & 20 & Do. \\
\hline 21 & ............. & 27 & 18 & & 16 & $13 \frac{1}{2}$ & Lake silts (?) with basalt fragments. \\
\hline 22 & 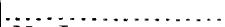 & 27 & 18 & & 22 & $21 \frac{\pi}{2}$ & Do. \\
\hline 23 & Mr. Lang. & 27 & 18 & & 23 & 22 & $\begin{array}{l}0-16 \text {, lake silts (?); } 16-23 \text {, basalt frag- } \\
\text { ments. }\end{array}$ \\
\hline 24 & J. A. Pond. & 27 & 18 & 21 & 20 & 20 & Alluvium and lake silts. \\
\hline 25 & John Ross & 27 & 18 & 7 & 21 & $19 \frac{1}{2}$ & Lake silts. \\
\hline 26 & Mr. Anderson. & 27 & 17 & & 27 & 20 & Do. \\
\hline 27 & (Auger hole). & 27 & 17 & & 20 & 17 & Sandy clay. \\
\hline 28 & ....do........ & 27 & 17 & & 20 & & Sands and moist clays. \\
\hline 29 & a...do & 26 & 17 & & $19 \frac{1}{2}$ & & $0-19$, sands and moist clay; $19-19 \frac{1}{2}$, tuff. \\
\hline 30 & ..... do & 26 & 16 & & $16^{2}$ & 13 & $\begin{array}{l}\text { Moist clay (at edge of alkaline pool, } \\
\text { PI. III, } C \text { ). }\end{array}$ \\
\hline 31 & .....do & 26 & 16 & & 3 & Dry. & Loose tuffaceous soil (?). \\
\hline 32 & ..... do & 26 & 15 & & $7 \frac{1}{2}$ & Dry. & $\overline{0}-6 \frac{1}{2}$, silt and sand; $6 \frac{1}{2}-7 \frac{1}{2}$, tuff. \\
\hline 33 & ..... do & 26 & 15 & & $16^{\circ}$ & 12 & $\begin{array}{l}\text { Silts, sands, and clays; } 8-9 \text {, moist } \\
\text { sand containing fresh-water shells. }\end{array}$ \\
\hline 34 & .....do. & 25 & 14 & & 4 & Dry. & Loose soil, from decomposed tuff. \\
\hline 35 & (Well) & 25 & 14 & & 26 & 25 & $0-25$, lake silts; $25-26$, tuff. \\
\hline 36 & (Auger hole) & 27 & 17 & & 26 & 24 & Silts, sands, and clays. \\
\hline 37 & .... do........ & 27 & 17 & & 7 & Dry. & $0-6$, silts and sand; $6-7$, tuff. \\
\hline 38 & $\ldots .$. do & 27 & 17 & & 5 & Dry. & $0-4$, lake silts; $4-5$, tuff. \\
\hline 39 & ..... do. & 28 & 16 & & 24 & 24 & $\begin{array}{l}0-16 \text {, lake silts and clays; } 16-24 \text {, moist } \\
\text { clay. }\end{array}$ \\
\hline 40 & ....do. & 28 & 16 & & 5 & Dry. & $0-4$, lake silts; $4-5$, tuff. \\
\hline 41 & & 28 & 16 & & 4 & Dry. & $0-3$, lake silts; $3-4$, tuff. \\
\hline 42 & (Well). & 28 & 16 & & 15 & Dry. & Lake silts. \\
\hline 43 & F. M. Chrisman & 28 & 14 & & 247 & 49 & $\begin{array}{l}\text { 0-108, lake silts and sands; } 108-223 \text {, } \\
\text { tuff; } 223-247 \text {, basalt (?). }\end{array}$ \\
\hline & Roy Ward & 28 & 14 & & 90 & Dry. & Lake silts (?). \\
\hline 45 & T. J. La Brie. & 28 & 14 & & 15 & 10 & Lake silts (near edge of marsh). \\
\hline 46 & Hayes Bros.. & 27 & 14. & & 10 & 5 & Do. \\
\hline
\end{tabular}

a Locations indicated by corresponding numbers on fig. 1, p. 60 .

Throughout the settled area the soil is composed of sands and sediments, which extend to a considerable depth. No coarse gravels are met. The sink of Peter Creek, which at first glance seems to be a separate valley, is really connected with the main valley by a broad drainage channel to the east of Bunchgrass Butte, and the same fine sediments are found in it as in the main part of the valley. In four of the five wells examined in the sink the water level is 20 to 25 feet below the surface, and the water is of good quality, the electrolytic bridge ${ }^{a}$ indicating an alkaline content of 30 to 40 parts in 100,000. The fifth well is in the southwest end of the so-called sink, near the 
basalt rim. It has been dug 25 feet deep, passing through the usual silts at a depth of about 18 feet, and penetrating the remainder of the distance into decomposed basalt, without finding water.

Several wells along the northern side of "Sucker Flat" have also reached the basalt at depths of 10 or 12 feet. A small amount of water of fair quality has been found at this depth. Well No. 9 also reaches basalt at a depth of 11 feet, but its water is much more alkaline than that of the others. Half a mile north of this well basalt has been found only 2 or 3 feet below the surface, although there is no indication in the character of the brush that the soil here is so shallow. As shown by the wells farther south in the flat, the soil in that part is deeper. Basalt has not been found in them at a maximum depth of 31 feet in well No. 19. The ground-water level varies from about 10 feet below the surface near Cliff post-office to 25 feet near Christmas Lake. The material in which water is found varies in texture from sandy to clayey.

South and west of Christmas Lake the waters are as a rule of better quality than in the area near Fossil Lake. In October, 1906, the water level was about 20 feet below the surface and the mineral content was from 25 to 50 parts in 100,000 . In all of the wells it has been noticed that on standing for any length of time the water becomes more strongly alkaline and has an odor as of decaying organic matter. In one well, near No. 15, even though in constant use, the water became so strong as to necessitate the digging of another well.

The wells on the south side of the valley show that the sediments thin out there as on the north. Fragmental volcanic material is met near the bottoms of wells Nos. 21, 22, and 23, which, being from 16 to 23 feet deep, are extended only a foot or so below the water level.

West and northwest of Sevenmile Ridge a number of auger holes were put down, which indicate that the tuff exposed in this ridge, in the hills near Table Rock and in Fort Rock, underlies this part of the valley at shallow depths. Some irregularities in its surface have perhaps formed basins, as at test holes Nos. 33 and 39, where water was found at depths of 12 and 24 feet, respectively; but in others a hard material, probably the tuff, was encountered at 3 to 20 feet below the surface.

A short distance south of Fort Rock a well 25 feet deep has been dug, which passes through 25 feet of the usual light-colored silts into the tuff. The water was 1 foot deep in October, 1906, and although it evidently had been standing a long time, contained only 40 to 50 parts of solids in 100,000 .

There were no wells in the southeast arm of the valley and no test holes were sunk in it, but Mr. A. W. Long, of Lake, reports having found water at a depth of 15 feet at one point in this area. Its general character indicates water conditions similar to those near Fossil Lake rather than to those of the western part of the valley. 


\section{ANALYSES OF WATERS.}

Analyses of three well waters of this valley were made, those of James Wilson (well No. 12), J. C. Green (well No. 14), and John Ross (well No. 25). These are given in Table C, on page 72 (samples C, D, and $\mathrm{E}$ ), and show alkaline contents, respectively, of $36.8,235$, and 432.8 parts in 100,000 . There is no change in the character of the surface to indicate why the water at Mr. Wilson's should be so much purer than that at Mr. Green's, except that the former is nearer the edge of the valley. In digging Mr. Ross's well a lump of gypsum (sulphate of lime) a foot long and 6 or 8 inches in diameter was found at a depth of 14 or 15 feet (water being struck at $19 \frac{1}{2}$ feet); this makes the high percentage of sulphate in this water not surprising. Its mineral character is distinctly appreciable to the taste.

\section{SPRINGS.}

Close to the western shore of Christmas Lake there is a well 9 feet deep, in which the water stands about 5 feet below the surface. Its temperature in October, 1906 , was $62^{\circ} \mathrm{F}$, both on cold mornings and at midday. Its mineral content is about 40 parts in 100,000 . It is said that originally there was a spring here, but that when the willows and nearby sage were cleared off it was soon buried by sand and was reopened only by digging this well.

Christmas Lake is fed by an intermittent spring at its south end. Fossil Lake is also said to be fed by a spring near its center, from which, it is claimed, range riders have drunk when the lake was dry.

The most interesting springs in the valley are those known as Mound Spring and Sand Springs. These rise in the sands of the area east of Fossil Lake, forming valued watering places for stock. Mound Spring is the larger, having a flow of about 2 miner's inches in October, 1906, which supplied a pond 75 yards across. The water is sulphurous in taste and rises with a temperature of $62^{\circ} \mathrm{F}$. Sand Springs, one-third mile northward, are no doubt of the same origin, but the flow is less, being, as nearly as could be measured, about $1 \frac{1}{2}$ inches. The nearness of these springs to the sand dunes is shown in Pl. IX, $C$.

\section{DEEPER ALLUVIAL WATER.}

It has been stated in preceding pages that wells along the edges of the valley show that basalt there underlies the sediments at shallow depths. The low dips of the beds in the surrounding basalts, and a basaltic ridge that extends southward from Bunchgrass Butte, indicate that the lake sediments are not very deep at any point in the valley, nor do extensive alluvial slopes exist along its sides. So, while a larger supply of better water than that of the present shallow wells may be found deeper below the surface, it does not seem probable that flowing wells can be developed in the lake sediments of this valley. 


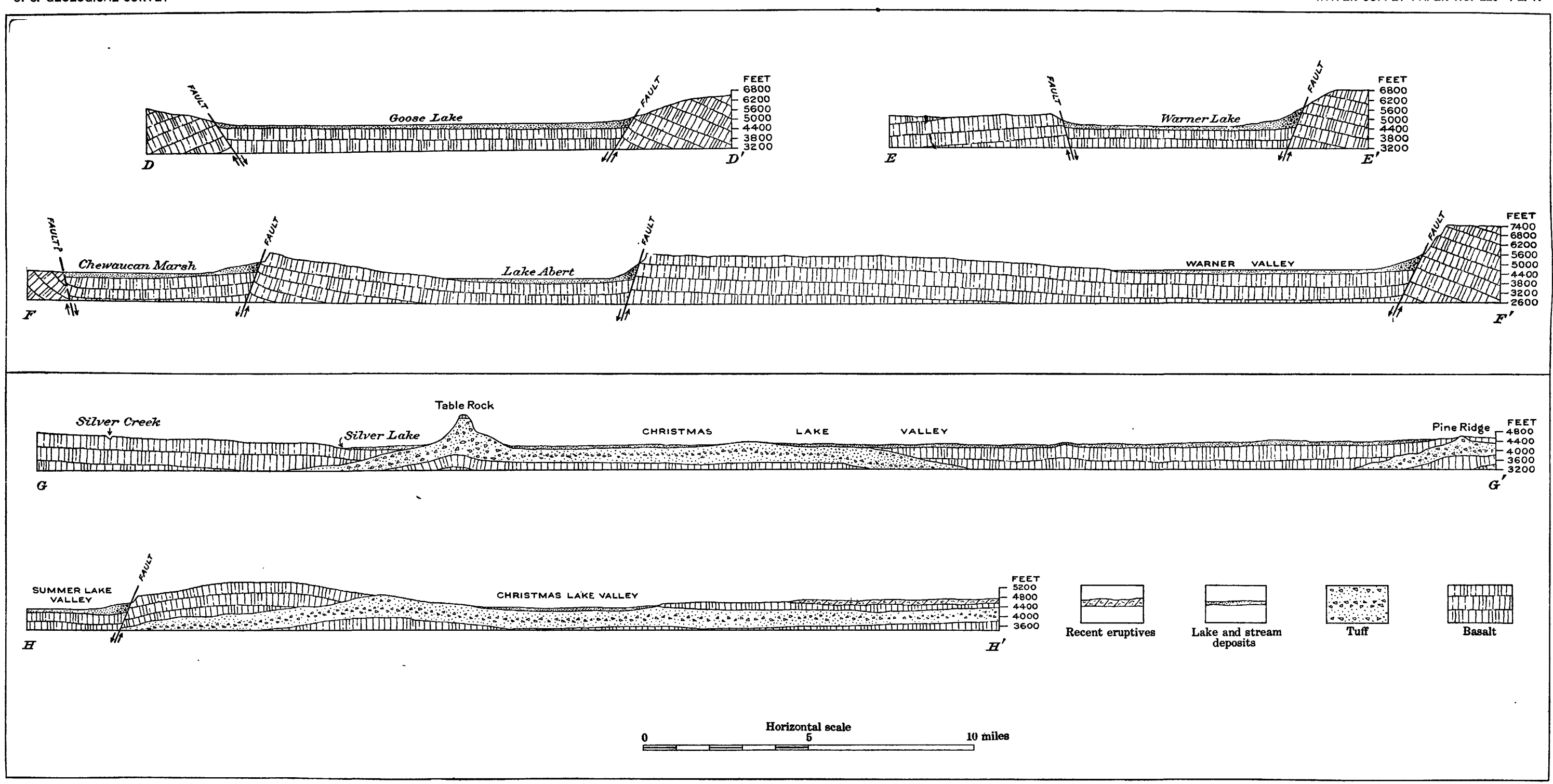

APPROXIMATE GEOLOGIC SECTIONS ALONG LINES SHOWN ON PL. VI.

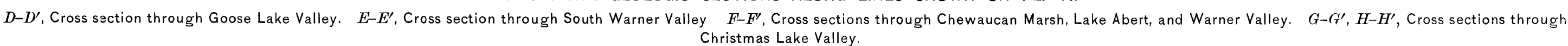



Structural conditions.- The structural conditions affecting the existence of flowing artesian water in the rocks underlying this valley may be stated briefly as follows: All along the valley's southern border the lava sheets dip uniformly toward the valley at low angles; on the eastern side also the slope is gentle toward the valley. The structure to the north is largely obscured by the recent lava flows, but the older beds appear to be nearly horizontal; as exposed where they form the slopes to the sink of Peter Creek, however, they also appear to dip slightly toward the valley. On the west the Conley Hills and the eastward-dipping tuff ridge near Table Rock probably separate Christmas Lake Valley structurally from Silver Lake Valley. Within the valley itself there are at least two irregularities in the shallow basinlike structure. From Bunchgrass Butte a low basalt ridge extends southward toward the projecting scarp on the opposite side of the valley, and in Sevenmile Ridge there is a similar low peninsulalike ridge, but of tuff, pointing toward isolated blocks of the same material on the north side of the valley. In the tentative sections ( $\mathrm{Pl} . \mathrm{X})$ the structure as interpreted is shown.

From these features it appears that in addition to the general low synclinal structure of the valley as a whole there is also a tendency toward folding along axes trending north and south. If this interpretation is correct the valley is divided into three shallow basins, the eastern basin being that of Fossil Lake, the central that of Christmas Lake, and the third the desert west and northwest of Sevenmile Ridge.

Favorable indications.-These minor secondary folds probably do not affect the likelihood of the existence of artesian water, for they are slight, and tend only to divide the valley, not to prevent the percolation toward it of deep water. The valley as a whole is a structural trough, and therefore the chances of obtaining deep water under pressure seem favorable. The absence of extensive faulting is also a condition which is favorable to the presence of rock water under pressure and which was not found in the southern valleys.

As before stated, the temperature of Mound Spring is $62^{\circ}$, while the mean annual temperature of the valley is about $44^{\circ}$. Assuming the usual increase of temperature with depth as $1^{\circ} \mathrm{F}$. for each 50 feet, the water of this spring probably rises from a depth of 900 feet.

The presence of this warm spring, and possibly also the same temperature of the well at Christmas Lake, must be taken as indicating that deep water under pressure does exist under this valley.

In the Connell-Ritzville district, in east-central Washington, ${ }^{a}$ water is obtained at an average depth of 325 to 400 feet, in decomposed or

a Calkins, F. C., Geology and water resources of a portion of east-central Washington: Water-Sup.

Paper No. 118, U. S. Geol. Survey, 1905, pp. 69-75. 
fragmental basalt. None of the wells have been cased, but in several artesian pressure causes the water to rise a considerable height above the level at which it is struck, and it probably would rise to the surface if properly tapped. This is in a very gently sloping area, the dip of the beds being hardly appreciable to the eye. It is thought that the water of the district must come from a long distance, from the higher northwestern country, to attain the pressure that it has. Such a condition exists on a larger scale in the northern Mississippi Valley, where the surface exposure of the water-bearing Dakota sandstone is found many miles from the artesian localities.

The Pauline Mountains lie about 30 miles north of Christmas.Lake Valley. About the same distance west of Silver Lake Valley is the Walker Range, an eastern spur of the Cascades. Neither of these ranges was visited, but they are thought to consist of the same series of basalts that cover most of Lake County, and it seems not improbable that the rocks dip from them toward Christmas Lake and Silver Lake valleys, and that an underground water supply such as exists in central Washington may reach these valleys from those sources.

On the whole, while the data concerning the underground conditions within these two valleys are meager, the indications in favor of the existence of deep waters are sufficient to warrant the sinking of test wells. This matter has been seriously considered, especially since the settlement of Christmas Lake Valley. During the fall of 1906 it seemed about to assume definite shape, and it is hoped that work on a deep boring will soon be begun.

\section{ALKALI LAKE VALLEY.}

One other valley, that of Alkali Lake (Pl. VII, $B$, p. 26), in the northeastern part of the county, was examined in some detail. This valley is about 20 miles long from north to south and about onefourth as wide, being partially divided into two basins by the spur of hills north of the playa known as Alkali Lake. In each of the basins the surface is nearly level, its chief irregularities being the sand ridges or the hillocks of fine silts previously described. The area around the lake is for the most part a greasewood flat, in which the alkali is very evident; during storms the soil becomes a slippery mud that, on drying, is caked by the soda salts to a hardpan surface. In North Alkali there is some better looking land, but it is rather "spotty," being in some places loose and sandy, with a good growth of sage, and in other places a hard, fine silt with but a scanty covering of greasewood.

On the east the basin is bordered by a scarp which is 1,200 feet in height in its southern portion, but which dies out toward the upper end of the depression. In other directions the basalt slopes rise gently to the higher desert plateau. 
Through Venator Canyon on the northeast and a gorge at the northern end gravels have been brought down from the slopes of Little Juniper Mountain, and in the northwestern arm of the valley flood waters have deposited coarse sands and gravels, but elsewhere only fine sands and sediments are to be seen.

The only house in this valley is on the west edge of Alkali Lake. It is a usual stopping place for travelers and range riders, and although permanently occupied by tenants who care for stock on the surrounding range, no attempt has been made at agriculture, for the soil is too alkaline.

In the looser soil at the north end of North Alkali Valley a few acres were cleared by a prospective settler, and grain raised; but attempts to get water failed, several wells reaching basalt at shallow depths, and the claim has been abandoned.

The only spring of importance in this valley is that at the west edge of Alkali Lake, at the only ranch house in the valley, and it has long been known as the only watering place within a radius of 20 miles. It is said that in early days the pool where this spring rises was only 3 or 4 feet in diameter, but of great depth, and that range riders in attempting to sound it let down a weight several hundred feet without reaching botton. This is the usual legend about desert springs of this character and probably has no foundation in fact. Several years ago a levee was built around the spring to raise its water level and obtain better run-off to the lake, and a pond about 15 yards in diameter was thus formed. In this a weight could be lowered only 15 feet. The temperature of the water in this pond $\left(59^{\circ}\right)$, which is probably less than when it first rises, indicates that it is of deep origin, however; according to previously used assumptions, it comes from a depth of 700 to 800 feet. Small fish live in the pool. In October, 1906, this spring discharged from 2 to $2 \frac{1}{2}$ miner's inches, which is its average summer flow, but during the winter its yield is said to be somewhat greater. The water has been reported to contain borax, but although it was not tested for borates, the analysis (sample A, p. 72) shows it to contain only 28 parts of solid matter in 100,000 parts of water, all of which is accounted for in the salts determined.

In North Alkali Valley there is a playa whose surface is about 12 feet below the mean level of the basin. This depression is probably a "blow-out" that has been carved in the lake sediments by wind erosion. Along its northern side, during the spring and early summer, seepage springs furnish water for the range cattle, but they dry up later in the season. Similar springs appear along the northern edge of Alkali Lake after storms and sometimes during periods of cool, cloudy weather. The fluctuation of these springs is of interest in showing the summer lowering of the ground-water level and its 
changes due to weather conditions, as well as in indicating a seepage flow southward toward the lake, as would be expected.

Several auger holes that were put down in the valley filling in North Alkali Valley to a depth of 18 or 20 feet show it to be composed of fine silts interbedded with sands, as in Christmas Lake Valley; the water level in November, 1906, was about 15 feet below the surface.

As in the other valleys, water of better quality than that near the surface probably is present near the bottom of the sediments in this basin. But the evidence of extensive faulting along the eastern side of the depression, as at Abert Lake, indicates that deep rock water under artesian head does not underlie this region, and therefore, even if the land were not for the most part too alkaline for agriculture, cheap water for the necessary irrigation would not be available. Hence it seems improbable that more than a few scattered homes can ever be established here.

\section{RECLAMATION PROJECTS.}

One-third of the entire area of the United States (exclusive of Alaska and outlying territories) is still vacant public land. But nearly all of this that is susceptible of being tilled lies within the arid regions, or those having an average annual rainfall of less than 20 inches; and there are now in these regions few localities where homes can be easily made, owing to the great cost of developing water. It is for this reason that the Reclamation Service has been established, to aid in settling and rendering productive the great arid tracts, by constructing dams, reservoirs, and canals to supply the needful water for irrigation. ${ }^{a}$

Much of the valley land of Lake County was temporarily withdrawn from entry a year or more ago, pending the examination of the Silver Lake, Chewaucan, and Ana River reclamation projects. Part of the

$a$ The following extracts from the reclamation law, approved June 17, 1902, contain its main terms and prowisions:

"SEc. 1. * * * All moneys received from the sale and disposal of public lands in Arizona, California, Colorado, Idaho, Kansas, Montana, Nebraska, Nevada, New Mexico, North Dakota, Oklahoma, Oregon, South Dakota, Utah, Washington and Wyoming * * shall be * * appropriated as a special fund in the Treasury to be known as the 'reclamation fund ' to be used in the examination and survey for and the construction and maintenance of irrigation works for the storage, diversion, and development of waters for the reclamation of arid and semiarid lands in the said States and Territories. * * *,"

"SEc. 3. That the Secretary of the Interior shall $* * *$ withdraw from public entry the lands required for any irrigation works contemplated under the provisions of this act, and shall restore to public entry any of the lands so withdrawn when, in his judgment, such lands are not required for the purposes of this act; and the Secretary of the Interior is hereby authorized, at or immediately prior to the time of beginning the surveys for any contemplated irrigation works, to withdraw from entry, except under the homestead laws, any public lands believed to be susceptible of irrigation from said works; *** that public lands which it is proposed to irriga te by means of any contemplated works shall be subject to entry only under the provisions of the homestead laws in tracts of not less than forty nor more than one hundred and sixty acres, and shall be subject to the limitations, charges, terms, and conditions herein provided: Provided, That the commutation provisions of the homestead laws shall not apply to entries made under this act.

"SEC. 4. That upon the determination by the Secretary of the Interior that any irrigation project is practicable, he may cause to be let contracts for the construction of the same $* * *$ and $* * *$ 
land in Christmas Lake Valley was again restored and opened to entry in September, 1906, but the greater part of the vacant land susceptible of irrigation under these three projects is still withdrawn. These projects are necessarily only tentative, and until several years' measurements of the streams indicate the supply of water that can be depended upon no further action can be taken.

Here, as elsewhere, the Government has taken an important preliminary step toward conserving the water supply by creating the Goose Lake and Fremont forest reserves, for (with the possible exception of Ana River) all the streams are fed from the wooded mountain slopes, where protection and conservation of the scanty supply of moisture is of the utmost importance to any proposed irrigation project.

Under the provisions of the Carey $\operatorname{Act}^{a}$ the construction of a reservoir on the upper Chewaucan River and irrigation of much of the lower land has been considered, but nothing has yet been done.

\section{SOILS.}

ANALYSES.

Samples of the soil and water were collected at several places in the county and were analyzed by $\mathrm{Mr}$. W. H. Heileman, engineer of soils at Berkeley, Cal.

The soils were taken from near the surface of the uncultivated lands, which at the time the samples were collected (in October) probably contained their maximum amount of alkaline salts, so they are not fair samples. They were taken thus on the assumption that after the dry summer months the soil near the surface would be the most alkaline and would indicate the extreme conditions to be met. It is to be regretted, however, that samples of the deeper soil were not obtained, in order that the question whether there is a great quantity of salts present and danger of their rising with irrigation and cultivation, might have been answered.

shall give public notice of the lands irrigable under such project, and limit of area per entry, which limit shall represent the acreage which, in the opinion of the Secretary may be reasonably required for the support of a family upon the lands in question; also of the charges which shall be made per acre upon the said entries, and upon lands in private ownership which may be irrigated by the waters of the said irrigation project, and the number of annual installments, not exceeding ten, in which such charges shall be paid and the time when such payments shall commence. The said charges shall be determined with a view of returning to the reclamation fund the estimated cost of construction of the project, and shall be apportioned equitably.

"SEc. 5. That the entryman upon lands to be irriga ted by such works shall, in addition to compliance with the homestead laws, reclaim at least one-half of the total irrigable area of his entry for agricultural purposes, and before receiving patent for the lands covered by his entry, shall pay to the Government the charges apportioned against such tract, as provided in section four." * * *

$a$ According to the Carey Act of 1894 , the Cnited States may grant and patent to any of the arid States or Territories, free of cost, a total area not exceeding $1,000,000$ acres which " the State may cause to be irrigated, reclaimed, occupied, and not less than twenty acres of each one hundred and sixty acre tract cultivated by actual settlers, * * * as thoroughly as is required of citizens who may enter under the desert-land law." After filing an approved map of the land and plan of irrigation, the State is authorized to make necessary contracts and induce settlement, but is not authorized to lease the lands or dispose of them in any way except to secure reclamation. A maximum of 160 acres can be held by one person, and the surplus over cost of reclamation, derived from the sale, is to be held as a trust fund to be applied to the reclamation of other lands in the same State. 


\section{Following are the results of the soil and water analyses:}

TABLE A.-Alkali content of water extract on surface soils of Lake County, Oreg.

[Figured as sodium salts. Amounts are percentages. W. H. Heileman, analyst.]

\begin{tabular}{|c|c|c|c|c|c|c|}
\hline No. & Locality. & $\begin{array}{l}\text { Water- } \\
\text { soluble } \\
\text { salts in } \\
\text { soil. }\end{array}$ & $\begin{array}{l}\text { Sodium } \\
\text { chloride. }\end{array}$ & $\begin{array}{c}\text { Sodium } \\
\text { bicar- } \\
\text { bonate. }\end{array}$ & $\begin{array}{l}\text { Sodium } \\
\text { sulphate. }\end{array}$ & $\begin{array}{l}\text { Sodium } \\
\text { carbon- } \\
\text { ate. }\end{array}$ \\
\hline 1 & Thousand Spring Valley & 1.12 & 0.30 & 0.22 & 0.59 & 0.02 \\
\hline 2 & 3 miles west of Christmas Lake. & .19 & .02 & .07 & .11 & 0 \\
\hline 3 & One-half mile south of Christmas Lake. & 2.85 & .75 & .07 & 2.03 & \\
\hline 4 & Well No. $21 \ldots \ldots \ldots \ldots \ldots \ldots$ & .17 & .02 & .09 & .07 & \\
\hline 5 & North end of sink of Peter Creek & .18 & .03 . & .08 & .07 & \\
\hline 6 & 1 mile south of Fossil Lake... & 2.46 & .30 & .08 & 2.08 & \\
\hline 7 & One-half mile east of Cliff post-office.. & .09 & .01 & .05 & 0 & \\
\hline 8 & Center of North Alkali flat & .08 & .02 & .03 & 0 & \\
\hline 9 & Western arm of Alkali basin & .06 & & .04 & 0 & \\
\hline
\end{tabular}

TABLE B.-Plant-food analyses of soils represented in Table A.

[Results are in per cent on air-dry soil. Analysis acid extract; Official Association method. W. H. Heileman, analyst ]

\begin{tabular}{|c|c|c|c|c|c|c|}
\hline No. & $\begin{array}{l}\text { Insolu- } \\
\text { ble resi- } \\
\text { due. }\end{array}$ & $\begin{array}{l}\text { Mois- } \\
\text { ture. }\end{array}$ & $\begin{array}{l}\text { Organic } \\
\text { and vol- } \\
\text { atile. }\end{array}$ & $\begin{array}{c}\text { Calcium } \\
(\mathrm{CaO}) .\end{array}$ & $\begin{array}{l}\text { Phos- } \\
\text { phoric } \\
\text { acid } \\
\left(\mathrm{P}_{2} \mathrm{O}_{5}\right)\end{array}$ & $\frac{\text { Potash }}{\left(\mathbf{K}_{2} \mathrm{O}\right)}$ \\
\hline 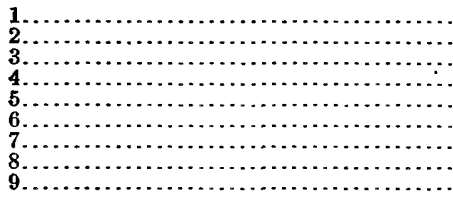 & $\begin{array}{l}73.45 \\
77.68 \\
66.62 \\
73.22 \\
78.67 \\
58.07 \\
79.14 \\
79.24 \\
76.85\end{array}$ & $\begin{array}{l}1.89 \\
2.79 \\
3.61 \\
3.23 \\
2.30 \\
4.20 \\
1.97 \\
2.56 \\
2.33\end{array}$ & $\begin{array}{r}6.50 \\
3.23 \\
5.80 \\
4.08 \\
5.00 \\
10.96 \\
3.65 \\
4.22 \\
4.59\end{array}$ & $\begin{array}{r}5.65 \\
1.51 \\
5.17 \\
2.51 \\
1.88 \\
10.70 \\
1.41 \\
3.16 \\
1.06\end{array}$ & $\begin{array}{r}0.18 \\
.14 \\
.19 \\
.05 \\
.11 \\
.38 \\
.13 \\
.12 \\
.11\end{array}$ & $\begin{array}{r}1.11 \\
.73 \\
1.01 \\
.51 \\
.30 \\
.56 \\
.54 \\
.51 \\
.56\end{array}$ \\
\hline
\end{tabular}

TABLE C.-Analyses of waters from southern Oregon.

[W. H. Heileman, analyst.]

\begin{tabular}{|c|c|c|c|c|c|c|}
\hline & A. & B. & C. & D. & E. & F. \\
\hline Total solids $\alpha_{*}$. & 28.00 & 10.00 & 36.8 & 235.00 & 432.80 & 22.00 \\
\hline $\begin{array}{l}\text { Calcium (Ca) } \\
\text { Magnesium }(\mathrm{Mg}) . .\end{array}$ & $\begin{array}{r}1.33 \\
.82\end{array}$ & $\begin{array}{r}1.28 \\
.51\end{array}$ & $\begin{array}{l}2.24 \\
1.70\end{array}$ & $\begin{array}{l}5.56 \\
4.80\end{array}$ & $\begin{array}{l}8.20 \\
8.20\end{array}$ & $\begin{array}{l}1.18 \\
6.10\end{array}$ \\
\hline Sodium and potassium ( $\mathrm{Na}+$ & & & & & & \\
\hline $\begin{array}{r}\mathrm{K}) \\
\text { Sulphate }\left(\mathrm{SO}_{4}\right)\end{array}$ & $\begin{array}{l}8.24 \\
2.90\end{array}$ & $\begin{array}{r}1.38 \\
.17\end{array}$ & $\begin{array}{l}8.35 \\
2.51\end{array}$ & $\begin{array}{l}70.00 \\
88.00\end{array}$ & $\begin{array}{l}128.50 \\
204.00\end{array}$ & $\begin{array}{l}5.48 \\
1.24\end{array}$ \\
\hline Carbonate $\left(\mathrm{CO}_{3}\right) \ldots \ldots$. & .00 & .00 & .00 & .00 & .00 & .00 \\
\hline Bicarbonate $\left(\mathrm{HCO}_{3}\right) \ldots$ & 16.66 & 4. 40 & 25.30 & 78.80 & 44. 10 & 11.60 \\
\hline Chlorine (Cl) & 3.44 & .61 & 1.97 & 15.25 & 57.40 & 3.94 \\
\hline Nitrate $\left(\mathrm{NO}_{3}\right)$ & .00 & .00 & .00 & Trace. & Trace. & .00 \\
\hline $\begin{array}{c}\text { Total solids by summa- } \\
\text { tion } \ldots . . . \ldots \ldots \ldots \ldots \ldots\end{array}$ & 33.39 & 8.35 & 42.07 & 262.41 & 450.40 & 29.54 \\
\hline
\end{tabular}

a In a letter accompanying the above analyses Mr. Heileman states that "Total solids" means total mineral solids "determined by evaporating a known portion of the clear water to dryness and weighing the residue. In an evaporation there is always a loss of certain acid radicles, principally carbonate and bicarbonate, or at least a change in these two radicles. The effect of this is to make the total solids as directly determined lower in parts than is the summary of the analysis. There is good ground for assuming that the difference between total solids and the summary of the analysis is due to a loss in the bicarbonates in the total solids determination."
A. Spring at Alkali Lake.
B. Stream at A. Eglis's, Wagontire Mountain.
C. Well of J. Wilson, near Fossil Lake.
D. Well of J. C. Green, near Fossil Lake.
E. Well of John Ross, Christmas Lake Valley.
F. Springs of Ana River. 
The most noticeable facts shown by these analyses are the absence of carbonates in the waters and in all the soils except that of Thousand Spring Valley, and the high sulphate content, to which salt the bicarbonate and chloride are of secondary importance. The three soils having highest sulphate content (samples 1, 3, and 6) are also the highest in chloride, containing percentages of these white alkalis that are considered to be the limit of tolerance for nearly any crop. For ordinary crops this limit is usually placed at 0.05 to 0.10 per cent - for the carbonate of soda and 0.25 to 0.50 per cent for the chloride, while nearly 1 per cent of the sulphate may be endured. So it is seen that, with the exception of sample No. 1 (from J. H. Bonham's ranch, in Thousand Spring Valley), which has been found by trial too alkaline for plant growth, and Nos. 3 and 6 , which were taken from evidently alkaline areas, the surface soils do not contain enough of the alkalis to be seriously detrimental.

\section{SOIL CONSTITUENTS.}

In Hilgard's recent work on soils the effects of the several valuable constituents of the soil, as well as of the alkalies, are fully treated. From his deductions the following extracts are taken: ${ }^{a}$

\section{INSOLUBLE RESIDUE.}

About 69 per cent has been found to be the general average of insoluble matter in soils of arid regions throughout the United States. This consists chiefly of free silica (quartz), but the hydrous silicates, forming most of the material known as clays, are also usually included under this head. With this proportion the soils analyzed are seen to agree fairly well.

\section{LIME.}

Physically even a small amount of lime carbonate, by its solubility in the carbonated soil water, will act most beneficially in causing the flocculation of clay and in the subsequent conservation of the flocculent or tilth condition by acting as a light cement, holding the soil crumbs together when the capillary water has evaporated, thus favoring the penetration of both water and air and of the roots themselves. * * * Amounts of lime carbonate in excess of 2 per cent do not add to the favorable effects, except as would so much sand.

As to chemical effects, among the most important are-

1. The maintenance of the neutrality of the soil by the neutralization of acids formed by the decay of organic matter or otherwise.

2. The maintenance, in connection with the proper degrees of moisture and warmth, of the conditions of abundant bacterial life, * * * more especially those of nitrification, thus supplying the readily assimilable form of nitrogen; also in favoring the development and activity of the root bacteria of legumes and of the other nitrogengathering bacteria, such as Azotobacter.

3 . The rendering available, directly or indirectly, of relatively small percentages of plant food, notably phosphoric acid and potash. * * *

4. The prompt conversion of vegetable matter into black, neutral humus and (as shown in the case of the soils of the arid region) the concentration of the nitrogen in 
the same, while accelerating the oxidation of the carbon and hydrogen, as shown by S. W. Johnson and others.

7. In alkali soils, according to Cameron and May, it counteracts the injurious action of the soluble salts upon the growth of plants, not only in the form of carbon. ate, but also in those of sulphate and chloride.

An average arid-region soil as given by Mercker, Halle station, Germany, ${ }^{a}$ contains 1.36 per cent lime, 0.73 per cent potash, and 0.12 per cent phosphoric acid. For a "good" soil he gives the lime (in a sandy soil) at 0.20 to 0.30 per cent; potash, 0.25 to 0.40 per cent;" phosphoric acid, 0.15 to 0.25 per cent; from which it is seen that the arid soils are usually low in phosphoric acid but high in lime and potash.

With these results the soil analyses (Table B, p. 72) are seen to compare fairly well, being (with the exception of No. 6) rather low in phosphoric acid but high in lime. Sample No. 6 contains a very high lime content-too high, in fact, as it may cause marliness and render the soil unfavorable to plant growth unless properly handled.

In general, however, the results of these analyses are satisfactory, showing the soils to be not far different from those of other fertile though arid valleys. They are well supplied with lime, potash, and organic matter, but are rather low in phosphoric acid.

\section{SALTS PRESENT.}

Around the lake edges and some playas of the higher lands efflorescent saline crusts form. Ten of these were analyzed to determine the proportion of the several salts present, and the results are given in the following table:

Tests on alkali samples (mostly crusts).

[Results show percentage, figured on material analyzed. W. H. Heileman, analyst.]

\begin{tabular}{|c|c|c|c|c|c|c|c|c|}
\hline \multirow[b]{2}{*}{ No. } & \multirow[b]{2}{*}{ Locality. } & \multirow[b]{2}{*}{$\begin{array}{c}\text { Sulphates } \\
\left(\mathrm{SO}_{4}\right) \\
\text { Qualitative } \\
\text { only except } \\
\text { No. } 7 .\end{array}$} & \multirow[b]{2}{*}{$\begin{array}{l}\text { Carbon- } \\
\text { ates } \\
\left(\mathrm{CO}_{3}\right)\end{array}$} & \multirow[b]{2}{*}{$\begin{array}{l}\text { Bicar- } \\
\text { bonates } \\
\left(\mathrm{HCO}_{3}\right)\end{array}$} & \multirow[b]{2}{*}{$\begin{array}{l}\text { Chlorine } \\
\text { (Cl). }\end{array}$} & \multicolumn{3}{|c|}{ Calculated as sodium salt. } \\
\hline & & & & & & $\begin{array}{l}\text { Sodium } \\
\text { carbonate } \\
\left(\mathrm{Na}_{2} \mathrm{CO}_{3}\right)\end{array}$ & $\begin{array}{c}\text { Sodium } \\
\text { hicarbon- } \\
\text { ate } \\
\left(\mathrm{NaHCO}_{3}\right) .\end{array}$ & $\begin{array}{l}\text { Sodium } \\
\text { chloride } \\
\text { (NaCl). }\end{array}$ \\
\hline 1 & $\begin{array}{l}\text { East side Summer } \\
\text { Lake. }\end{array}$ & Heary ..... & 14. 28 & ต. 93 & 051 & 25.28 & 13.50 & 0.84 \\
\hline 2 & South end Christ- & .... do. & 6. 02 & 465 & .38 & 10.65 & 6.32 & .63 \\
\hline $3 b$ & West side Alkali & $\ldots . d o \ldots .$. & 6.74 & 4. 66 & 6.23 & 11.93 & 6. 34 & 10.28 \\
\hline 4 & Edge of pool in Al- & .... do.... & 14.64 & 9.07 & 15.35 & 25. 90 & 12. 33 & 25.31 \\
\hline 5 & $\begin{array}{l}\text { Center of Alkali } \\
\text { Flat. }\end{array}$ & .... do. & 274 & $\$ .77$ & .71 & 6.62 & 11.92 & 1.17 \\
\hline 6 & $\begin{array}{l}\text { Eastern pool north- } \\
\text { west of Christmas } \\
\text { Lake. }\end{array}$ & Very heavy. & .60 & .13 & 2.25 & 1.06 & .18 & 3.71 \\
\hline 7 & $\begin{array}{c}\text { Western pool } \\
\text { northwest of } \\
\text { Christmas Lake. }\end{array}$ & (c) & & & & & & \\
\hline 8 & $\begin{array}{l}\text { Efflorescence in } \\
\text { "Sucker Flat." }\end{array}$ & Heavy . . & .18 & .30 & 1.67 & .32 & .41 & 2.75 \\
\hline 9 & $\begin{array}{l}\text { Playa in North Al- } \\
\text { kali. }\end{array}$ & ..... do. & 8.07 & 6. 43 & 5.15 & 14.28 & 8.74 & 8.50 \\
\hline 10 & $\begin{array}{l}\text { North end Lake } \\
\text { Abert. }\end{array}$ & ......do. & 22.40 & 10.24 & 1.54 & 39.65 & 13.92 & 2.54 \\
\hline
\end{tabular}


From these analyses it is seen that the sulphate of soda (Glauber's salt) is the most abundant in all these deposits, as it is in the soils themselves.

The crust that forms over the playa of Alkali Lake is occasionally used as stock salt. As before stated, borax claims have been located in this flat, but analysis of the material shows it to consist, as elsewhere, of the sulphate, carbonates, and chloride of soda; there can be but little borax (biborate of soda) in this deposit.

The pools about 10 miles northwest of Christmas Lake, from which samples Nos. 6 and 7 were obtained, are shown in Pl. III, $C$ (p. 10). The salt, No. 7 , is also used for stock, but sometimes with injurious effects on the animals; nor is this to be wondered at, when analysis shows it to be nearly pure Glauber's salt.

\section{ALKALINE SOILS.}

The proper treatment of alkaline soils and the methods of farming in arid regions are treated in several bulletins of the Department of Agriculture, ${ }^{a}$ but a short discussion of the subject may not be out of place here.

\section{THE ALKALIES AND THEIR EFFECTS.}

The three chief salts known as alkali are the chloride, sulphate, and carbonate of soda, called respectively common salt, Glauber's salt, and sal soda. The two former are the white alkalies, while the latter is known as black alkali, since it turns organic matter with which it comes into contact brown or black. Borax also sometimes occurs as an alkali, but it is by no means as common as the others. The nitrate and phosphate of soda and the sulphate of potash also occur in nearly all soils, but as nutritive salts, essential to plant life, not as injurious ones.

Plants vary greatly in the amount of alkali they will endure. Members of the Goosefoot family, which includes the saltbushes and beets, will stand much of all three salts, while the legumes (peas and beans) resent small amounts of either. Common salt and Glauber's salt are by no means as harmful as the black alkali. In general-

\footnotetext{
* * * when present in soils to the exclusion of other salts, 0.05 per cent of sodium carbonate represents about the upper limit of concentration for common crops. Onehalf of 1 per cent of sodium chloride is commonly regarded as the endurance limit of crops, and 1 per cent of sodium sulphate. Sodium sulphate, then, is the least injurious and sodium carbonate the most injurious of the salts usually constituting the greater part of alkali under ordinary field conditions, while sodium chloride occupies a middle position. $b$
}

\footnotetext{
$a$ The following Farmers' Bulletins treat of subjects of especial interest to those living in the arid regions: No. 52, The Sugar Beet, 48 pp.; No. 77, The Liming of Soils, 24 pp.; No. 88, Alkali Lands, 23 pp.; No. 108, Saltbushes, 20 pp.; No. 139, Emmer: A Grain for the Semiarid Regions; 16 pp.; No. 215, Alfalfa Growing, 40 pp.; No. 266, Management of Soils to Conserve Moisture, 30 pp. These may be obtained free on application to the Secretary of Agriculture, Washington, D. C.

$b$ Dorsey, Clarence W., Reclamation of alkali soils: Bull. No. 34, Bureau of Soils, U. S. Dept. Agriculture, 1906, p. 10 .
} 
The chloride and sulphate seem to act largely by their presence in excess in the sap, reducing the vitality of the plant. The carbonate, attacking the bark of stalks and roots just beneath the surface, blackens it and makes it spongy, virtually girdling the tree or plant. This salt also has the property of puddling the soil when much moisture is present, and forms a hardpan surface.

The effect on plant life of the bicarbonates, which are also present in considerable amount, is but little understood, but it is not in general considered to be detrimental.

Analyses of soils made by Heileman both before and after prolonged irrigation indicate that by flooding methods of irrigation the bicarbonates are to some extent changed to carbonates, seeming to show that the carbonate salts are at all times unstable.

Hilgard ${ }^{a}$ also states that when irrigation ditches in sandy land saturate the soil, thus raising the water table and bringing close to the surface the entire mass of alkali salts and keeping them there for some time, "alkali salts originally 'white' will by chemical change become 'black' by the formation of carbonate of soda from the Glauber's salt, greatly aggravating the injury to vegetation."

\section{TREATMENT OF ALKALINE SOILS.}

In regions of slight rainfall it is of particular importance that as much of the moisture as possible be kept in the ground, near the surface, where it can best be taken up by plants. " The prevention of evaporation is the chief object in this endeavor, and is partially accomplished by shading the ground, as in the case of alfalfa and similar crops that furnish their own shade, by mulching with straw, or by frequent cultivation to keep the upper few inches of soil in a light, porous condition, so as to prevent further rise of moisture to the surface.

In arid lands brought under irrigation the increased evaporation often greatly accelerates the slower natural action of the ground waters in bringing to the surface and depositing soluble salts on evaporation, and regions formerly not alkaline, as the Yellowstone Valley near Billings, ${ }^{b}$ may become so by excessive irrigation.

Leaching down and washing out of the soil by thorough irrigation, where there is good underdrainage, is the best way of getting rid of these salts; but if the drainage is poor, the application of a minimum amount of water and cultivation to prevent its rise and evaporation is practiced to keep the salts down below the plant roots. For shallow-rooted crops, as the cereals, deep plowing, to turn the alkaline surface soil under, is also often of great benefit.

$a$ Hilgard, E. W., Nature, value, and utilization of alkali lands: Bull. No. 128, College of Agriculture, Univ. California, 1900, p. 6 .

$b$ Whitney, Milton, and Means, Thomas H., The alkali soils of the Yellowstone Valley: Bull. No. 14, Division of Soils, U. S. Dept. Agriculture, 1898. 
The chloride and sulphate can not be neutralized, but by the application of gypsum (land plaster) the carbonate may be changed to the comparatively harmless sulphate.

Theoretically the amount of gypsum to be applied should be onethird more in weight than the amount of soda in the land, but owing to impurities in the commercial material about twice the theoretical amount is necessary to neutralize all of the soda. It is not necessary to apply it all at once, but this should be done when rains or irrigation will carry the gypsum down and bring it into contact with the sodium carbonate. The gypsum also changes any borax that may be present to the harmless borate of lime. Two hundred pounds to the acre is an ordinary treatment, the effect being noticeable in two or three days by the disappearance of the discolored spots.

If in any of the valleys of Lake County it should be found desirable to use gypsum on parts of the land, it can probably be best obtained at Lime, on the eastern border of the State, where there is a deposit of good quality, as yet but little exploited.

Almost all of the alkaline salts are contained in the upper 4 or 5 feet of soil, and in level unirrigated lands they are often concentrated in the second or third foot. The amount of alkaline salts in a region is thus limited, and, aside from underdraining, may often be directly removed by collecting the crust by sweeping or with scrapers, and sometimes by planting and harvesting varieties of salt bush. Some of these take up nearly one-fifth of their dry weight of salts (mostly common salt), and hence materially reduce the alkaline content of the land.

\section{CONDITIONS IN LAKE COUNTY.}

It has been shown that throughout the valley lands of Lake County the chief alkali is the sulphate. The excess of lime in the soil, as has been stated, will to some extent compensate this, and with proper care in irrigating and plowing, it should not cause serious trouble. Neither are troubles from excessive irrigation and rise of the groundwater level apt to be serious in the valleys of Lake County, because of the fairly low present water level and the improbability of development of water to such an extent that it will be used lavishly. From the beginning, however, rather careful irrigation and cultivation immediately afterwards, is advisable, as the salts are much more easily kept down than gotten rid of when they have collected in serious amount.

The high productiveness of the arid lands when brought under cultivation, and the noxious salts removed or kept down, makes them valuable and well worth reclaiming; hence they are receiving more and more attention as other vacant lands become scarcer. 
CROPS ADAPTABLE TO ALKALINE SOILS.

Alfalfa when well started will stand a considerable amount of alkali, but the seed is extremely sensitive to black alkali, and is often killed before germination unless gypsum is used in sowing. Sugar beets are also adaptable to alkaline lands. Glauber's salt little affects their sugar-making quality, and a relatively large amount of common salt is required to render them unfit for this purpose. The cereals wheat, rye, and barley also resist moderate amounts of alkali. Root plants, however, such as potatoes, do not do well as a rule, tending to become watery when grown in alkaline ground.

Of fruits, there are few that will grow on the desert tracts where alkali, drought, and frost must to a greater or less extent be endured; but of those suitable to regions subject to frosts grapes, pears, and apples will stand the greatest amount of alkali. Of other trees, for shade or wood, the conifers (pines, firs, cedars, etc.) are very sencitive to black alkali and will not endure much white alkali, hence they are usually debarred from the lower valleys of arid regions. Cottonwoods will grow where water is near the surface, but they can not withstand drought. Other trees, as the red gum, which will withstand strong alkali, are susceptible to frost. Thus it is that, although pines, junipers, and cottonwoods are found along the margins, they do not grow native in the main parts of such valleys, which are given over to sage and salt bushes.

\section{COST OF DEEP WELIS.}

As few deep wells have been sunk in southern Oregon, there is among the settlers no definite idea of what such a well may cost. Figures showing the cost in other localities are therefore here introduced to indicate what may be expected in this matter.

In unconsolidated alluvial materials wells are often bored to depths of 50 feet or more, and up to 3 feet in diameter, with forms of the earth auger or lipped bucket. Such an outfit was used successfully in Christmas Lake Valley in the summer and fall of 1906 to put down several wells. This method, of course, can not be used in compacted or coarse material.

In deeper gravels and sands the California or "stovepipe" method is extensively used. In this method short sections of riveted steel pipe from 8 to 14 inches or more in diameter are sunk by hydraulic jacks, sometimes to a depth of more than 1,000 feet. The material within the casing is removed with a sand bucket or sand pump as the sinking proceeds, and the casing is perforated at water-bearing strata by a heavy cutting knife. This method is much used in southern California and in San Joaquin Valley in central California. 
The following tables, taken from Water-Supply Paper No. 137 of the United States Geological Survey, indicate the usual costs of such wells near Santa Ana, Cal.:

Cost, per foot, of drilling wells.

\begin{tabular}{|c|c|c|c|c|c|c|c|}
\hline & 4-inch. & 5-inch. & 6-inch. & 7-inch. & 8-inch. & 91-inch. & 10-inch. \\
\hline $\begin{array}{l}\text { First } 100 \text { feet } \\
\text { Additional for each } 50 \text {-foot ind }\end{array}$ & $\begin{array}{r}\$ 0.30 \\
.25\end{array}$ & $\begin{array}{r}\$ 0.30 \\
.25\end{array}$ & $\begin{array}{r}\$ 0.35-.40 \\
.20-.30\end{array}$ & $\begin{array}{r}\$ 0.40 \\
.20-.35\end{array}$ & $\begin{array}{l}\$ 0.40-.50 \\
.20-.35\end{array}$ & $\begin{array}{r}\$ 0.60-.65 \\
.20-.35\end{array}$ & $\begin{array}{r}\$ 0.65 \\
.35\end{array}$ \\
\hline
\end{tabular}

Following is the general price per foot of riveted steel casing made up into 2-foot joints of the sizes and gages generally used. The price varies, of course, with the steel market.

Cost of well casing.

\begin{tabular}{|c|c|c|c|c|c|}
\hline Diameter in inches & Gage. & $\begin{array}{l}\text { Price fer } \\
\text { foot. }\end{array}$ & Diameter in inches. & Gage. & $\begin{array}{l}\text { Price per } \\
\text { foot. }\end{array}$ \\
\hline 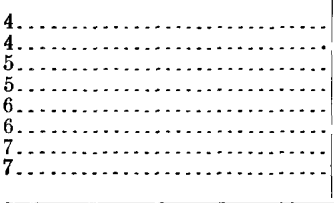 & $\begin{array}{l}16 \\
14 \\
16 \\
14 \\
16 \\
14 \\
16 \\
14\end{array}$ & $\begin{array}{r}\$ 0.32 \\
.38 \\
.35 \\
.43 \\
.42 \\
.50 \\
.48 \\
.55\end{array}$ & 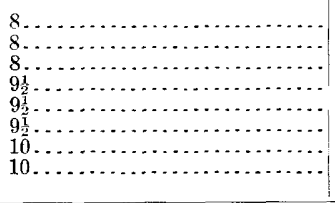 & $\begin{array}{l}16 \\
14 \\
12 \\
16 \\
14 \\
12 \\
16 \\
14\end{array}$ & $\begin{array}{r}\$ 0.55 \\
.64 \\
.78 \\
.65 \\
.75 \\
.94 \\
.68 \\
.78\end{array}$ \\
\hline
\end{tabular}

It should be remembered that these prices are for the material near centers of population; in a region like southern Oregon, therefore, the freight would make the cost considerably greater.

The hydraulic method has been successfully used in fine sediments where other methods have failed. A powerful jet of water just below the casing loosens the material and carries it upward out of the hole, so that by adding joints at the top the string of casing is rapidly sunk into the silts. Often a 4 -inch well can be sunk to a depth of 400 or 500 feet, cleaned out, and perforated in a couple of days. These wells are usually sunk by contract, cased and ready for use, for about $\$ 1$ a foot.

For penetrating rock, however, the oil rig, using a heavy drill bit alternately raised and dropped, is the only practical well-drilling outfit. The following costs of drilling in other localities are given to show what may be expected in Lake County if deep drilling is attempted. In southeastern Washington the following prices rule: ${ }^{a}$

The charges for well drilling in the southern part of the wheat lands [of Washington] are as follows: In soil, gravel, etc., above basalt, 50 cents a foot; in rock (which is generally in great part massive basalt, though other varieties after the first basalt is struck are not differentiated), $\$ 2.25$ per foot for the first 300 feet, and 50 cents per foot

$a$ Calkins, F. C., Geology and water resources of a portion of east-central Washington: WaterSupply Paper No. 118, U. S. Geol. Survey, 1905, p. 60. 
additional for each 100 feet below that depth. Water for the engine, coal, and board for the outfit are furnished by the owner of the ranch.

In the vicinity of Ritzville [Washington] the terms are slightly higher. For the first 300 feet there the charge is $\$ 2.50$, and 50 cents higher for each additional 50 feet. On these terms, however, the driller furnishes coal, the cost of which is estimated at about 25 cents for each foot drilled in basalt. In all cases water is guaranteed, and the risk of losing tools (which generally also necessitates abandoning the hole) is borne by the driller. The average cost of a well at these rates is probably not far from $\$ 800$, though it reaches a maximum of over $\$ 2,000$.

"Stovepipe" wells can probably be sunk with success in Summer Lake and Goose Lake valleys, and possibly also in those of Silver and Christmas lakes. But in the latter two, if drilling for deep water be attempted, the country rock, basalt, will be met beneath the sediments, and will probably have to be penetrated some distance before rock water, if such occurs, is struck. The idea, to some extent prevalent, that water will be found "if one only goes deep enough" is a fallacy; and if the bottom of the basaltic series should be reached and more siliceous rock encountered, like the rhyolite of Gray Butte or of Horning Bend, work might as well be stopped, for there is little hope of striking water-bearing strata in such rock. It is improbable, however, that such material will be encountered in these valleys at depths to which drilling is apt to be carried.

\section{SUMMARY.}

The reclamation of the fertile lands in eastern Oregon will depend on the available supply of water, for, as President Roosevelt said in his first message to Congress in 1901, "In the arid region it is water, not land, which measures production." On this account there will probably always remain some fertile land, as in the southwestern part of the United States, irreclaimable for lack of water. While in some parts of the arid regions dry farming of grain is carried on with more or less success, it is improbable that it can profitably be followed in the valleys that have been under discussion.

The supply of surface (stream) water available for irrigation in Lake County is fairly well known, and should it be developed it will by no means be sufficient to irrigate all of the arable land. The underground supply is as yet unknown, but on the whole, as has been shown, the indications seem favorable to the development of such water in the valleys of Silver, Christmas, and Summer lakes at least.

The reclamation of these valleys will not only increase the agricultural wealth of the State, but its stock-raising interests will also be greatly benefited. In severe winters the supply of wild hay from the marshes is very inadequate, and many head of stock perish every year from hunger and exposure. 
Grain, alfalfa, and sugar beets promise to be the chief crops in the valleys, and it seems that for several years to come nearly all produce will find a home market. The rocky high deserts will probably never be fit for other than grazing purposes, but if feed can be raised in the valleys, to carry greater numbers of sheep and cattle through the severe weather, the winter losses will be decreased and many more head of stock can be ranged in the country. The scarcity of water on the high deserts during the summer (when it is sometimes 30 miles between water holes) will remain a drawback to the grazing of cattle and sheep over these areas during this season. In other regions, as in Texas, wells have been sunk at intervals of 8 or 10 miles, and windmills and troughs supply this deficiency. But until tests have first been made in the more favorable localities, it can not be said whether it is possible or feasible thus to supply water on the Oregon plateaus. $48133-\mathrm{IRR} 220-08-6$ 



\section{INDEX.}

A.

bluffs bordering.

changes in ......................... 38

drainage to .................... $31,40,41$

evaporation from

40

scarp and landslide area near, view of... 12

section of, figure showing............. (it)

view of .................... 50

water of, analysis of ................. 13

Abert Lake basin, description of .......... $51-52$

Abrams, Le Roy, plants identified by...... 17

Acidic effusives, character and distribution of.

22

Acknowledgments to those aiding..........

Agriculture, character of ................. 19

Alkali, assays of ........................ 74

nature and effects of . ............... $75-76$ presence of.................... 11-14,74-75

Alkali Flat, alkali at, tests of............ 74

Alkali Lake, alkali at, use of............ 74

hills near, view of.................. 10

sink near, view of .................... 10

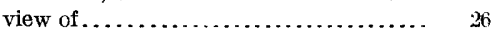

water of, analysis of ................ $\quad 72$

Alkali Lake valley, bluffs bordering ........ 10 description of .................... $38,68-70$ soil of, analysis of ................... 72 springs in ......................... $49-70$

Alkaline soils, crops adapted to........... 78 treatment of .................... $75,7 \mathrm{i}-77$

Alkaline water, electrolytic tests of........ 13

Alluvium, occurrence and character of..... 25 water supply and, relation of ......... 25

Analyses of soils, table of ............... 71 of waters, discussion of ............... 66

table of . ................ 72

Ana River, description of ................

flow of ...................... 40,41-42 source of . . . . . . . . .

springs of . . . . . . . .

water of, analysis of

Ana River project, status of . . . . . . . . . . $70-71$

Andesite, occurrence and character of..... 22

Animal life, character of ................. $\quad 17$

Antelope Valley, description of ............ 52

Artesian conditions, occurrence of........ 45$46,56-57,58-54,67$

B.

Basalt, occurrence and character of water in 47.55

Basaltic effusives, character and distribution of $23-24$
Page.

Beals, E. A., on Oregon climate......... 14

Bear Creek, description of ................ 32

flow of . ..................... 34, 35,40

Block stracture, occurrence of............ 25

origin of . . . . . . . . . . .

plates showing.................... 50,60

Bluffs. See Scarps.

Bonham, J. H., irrigation by............. 54

Bridge Creek, description of.............. 31-32

flow of .......................... 34, 35, 40

Buckhorn Creek, origin of.............. 54

Bullard Creek, flow of .................. $\quad 39$

Burns, well near...................... 48

C.

California, artesian water in ............. $\quad 46$

Carey Act, project under................. 71

Casing, well, cost of . . . . . . . . . . ...... 79

Chatard, T. M., on Abert Lake........... 13

Chewaucan Marsh, blufis bordering........ 10 evaporation from .................. 41 section of, figure showing............. 66

Chewaucan Marsh valley, description of.... 52-53 origin of . . . . . . . . . .

Chewaucan project, status of........... 70-71

Chewaucan River, description of .......... 31 flow of . . . . . . . . . . . . . . . . $33,35,40,55$

Chrisman, F. M., well of ................ 58

Christmas Lake, alkali at, test of....... 74,75 ground water near................ 65 springs at . . . . . . . . . . . . . . .

Christmas Lake valley, agriculture in..... 61 artesian possihilities in .............. 67

borings in ...................... $63-65$

burned area in, riew of ............. 58

description of . . . . . . . . . . . . . . . . . . . $59-68$

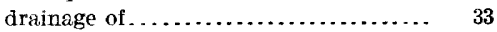

ground waters in . . . . . . . . . . . . $63-65,66$

character of ...................65-66

pamping in......................... 62

reservoirs in . . . . . . . . . . . . . . . . . . $62-63$

irrigation in . . . . . . . . . . .

lakes in . . . . . . . . . . . . . . . . . .

map of ............................ 60

pools in, view of .................. 10

rock waters in . . . . . . . . . . . . . . . $67-68$

sagebrush in, view of $\ldots \ldots \ldots \ldots \ldots \ldots . \quad 58$

sand hills in ...................... 11

section of, figure showing ............ 66

settlement in ..................... 59-60

soils of, analyses of ................. 72

springs in . . . . . . . . . . . . . $6 \ldots \ldots \ldots \ldots 67$

views in $\ldots \ldots \ldots \ldots \ldots \ldots \ldots \ldots \ldots \ldots, 58$ 
Page.

Christmas Lake valley, wells in

wells in, waters of, analyses of

63-65 66,72

Cliff (post-office), location of............. 59 soil near, analysis of ............... 72

Climate, character of . .................. 14-16

Colorado Desert, Cal., artesian water in ... 45

Condon, Thomas, work of................ 8

Connell-Ritzville district, Washington, rock water in.

Cope, E. D., work of

Cottonwood Creek, description of ......... 32

flow of .......................... $\quad 39$

Conley Hills, structure of ............. 59

Coyote Creek, description of . . . . . . . . . 31, 52

flow of ......................... 35,40

Coyote Hills, gold in ................... $\quad 20$

Crater Lake, evaporation from........... 41

Crooked Creek, description of............ 31 flow of ......................... 35, 11

Crooks Peak, altitude of............... 9

Crops, nature of . ............ 1ti-17, 19, 78,80-81

D.

Decomposition of soil, depth of .......... 44,45

Deep waters, oceurrence of . . . . . . . . . . . 46, 57

relation of, to rock structure......... 4 it-48

temperature of ................... 18

Deformation, effects of.................. $28-29$

Desert land law, provisions of.......... 41,62

Diller, J. S., on evaporation.............. $\$ 1$

Dorsey, C. W., on alkali................ 75

Drainage, lack of .................... $\quad 3,10$ See also Streams; Lakes.

Drews Creek, description of ............ $\quad 32$

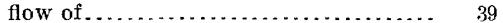

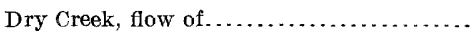

E.

Effusive rocks, character and distribution of $22-2,4$ Electrolytic bridge, tests of water by ..... 13

Elevations, data on.................. 9

Erosion, effects of . . . . . . . . . . . . . . . $29-30$

Eruptive rocks, character and distribution of......................... 24

Evaporation, rate of $\ldots \ldots \ldots \ldots \ldots \ldots \ldots+40-42$

\section{F.}

Fall River, flow of................... 43

Faults, occurrence and character of .... 25-26,28 relation of, to searps.............. $\quad 27$ relation of, to underground water..... $\quad 47$

Field work, extent of. .................. $7-8$

Folds, occurrence and character of ..... 26-27,28

Forests, relation of, to run-off. ........... 36-37

Forests, National, reservation of......... 71

Fort Douglas, Utah, evaporation at..... 41

Fort Rock, location and character of...... 23 view of ......................... 26 well near........................ 65

Fossil Lake, sand hills near............. 11 settlement at. ................... 59-60 soil near, analysis of ............... 72 springs at . . . . . . . . . . . . . . . . . . 59-60 wells near, water of, analyses of....... 72 See also Sucker Flat.

Frémont, John C., exploration hy ........ 20-2].
G.

Page.

Gannett, Henry, on evaporation... ...... 41

on Oregon lumber .................. 19-20

Geography, description of ............... 9

Geologic cross sections, plate showing.... 66

Geologic history, outline of ............. 27-31

Geology, account of .................. 21-31

Germany, soil of, lime in............... $\quad 74$

Glauber's salt, effects of . . . . . . . . . . . . . $75-76$

Gold, discovery of. ................... 20,21

foose Lake, bluffs bordering............. $\quad 10$ changes in ....................... 12,38

drainage to.................. $32,39,42-43$

evaporation from .................... 40,43

Goose Lake Valley, description of. . ....... 50-51 section of, figure showing............. 66 springs in ......................... 51

Grazing, industry of.............. 18-19,80-81

(7round water, level of .................. 44-45

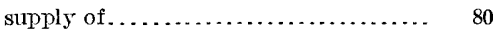
See also particular valleys, places, etc.

Gypsitm. neutralization by .............. $\quad 77$

$\mathrm{H}$.

Harney, well near.................... 48

Harney Basin, wells in................ 48

Heileman, W. H., analyses by .......... 71,76

High desert, deformation on............. 29 location and cha racter of. ............ 10

sink in, view of ................... 10

Hilgard, E. W., on soils. . . . . . . . . . . $73-74,76$

History of settlement, notes on........ 20-21

History, geologic, outline of............. 27-31

Honey Creek, description of. ........... 32-33,49

Hyd rography, description of. ........... 31-43

Hydrology, description of.............. 43-48

\section{I.}

Immigration, beginning of. ............. 21 Industries, deseription of.............. 18-20

Irrigation, relation of, to alkali........... 76

$$
\text { J. }
$$

Tohnson Creek, flow of. 40,55

source of.

Juniper Canyon, springs in . . ............. 54-55

K.

Kelly Creek, flow of.................... 39

Keno, evaporation at.................. 41

L.

Lakie deposits, description of.

Lakes, changes in. . ............... 12,30,37-38 character and distribution of . . . .... 9, 11-12 origin of........................ 30 views of ...................... $10,26,50$ water of, character of. .............. 12-14

Lake valleys, descriptions of .......... 49-70

Lakeview, rainfall at . . . . . . . . . . . . . 15-16,39 springs near......................... 51 temperature at................... 15 view of............................ 18 water supply of.................... 50

Landes, I., flow measurements by ......... $\quad 32$

Landslides, occurrence and character of.... 11.25 view of.......................... 12 
Page.

Lava, character and distribution of ....... 11

Lime, deposition of .................... 24 occurrence of, in soil................ 73-74

Lime (post-office), gypsum at .......... 77

Long, A. W., well of .................. 65

Lost Cabin gold district, mining in....... 20

Lost Creek, description of. ............. 33

Lumbering, work of . . . . . . . . . . . . . . . 19-20

\section{M.}

Map, geologic, of Oregon.............. Pocket.

Map, index, showing location of area ....... 7

- Map, reconnaissance, of south-central Oregon ...................... Pocket.

Mining, beginning of................. 20

Monoclines, relation of, to ground water... $\quad 47$

Moss Creek, description of.............. 31,52

flow of . ........................ 35,40

Mound Spring, description of. ..........66,67

Mountains, character and distribution of . .

N.

New Pine Creek, gold mining on......... 20 location of . ...................... 50

North Alkali Valley, alkali in, test of..... $\quad 74$ soil of, analysis of ................ 72 water in ...................... 69-70

Northern desert. drainage of............. 33

\section{O.}

Obsidan, occurrence and character of ..... 22 Oregon, geologic map of . . . . . . . . . . . . . . Pocket. maps of .................... 7 , Pocket.

\section{$\mathrm{P}$.}

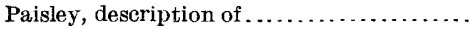

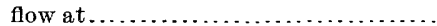
weather station at..................

Pauline Marsh, description of . . . . . . . . . . . evaporation from

Peter Creek, description of . . . . . . . . . . 33, 64 soil on, analysis of .................. 72 wells on.......................... 64-65

Physiography, development of . . . . . . . . 27-31

Plant life, effects of alkali on........... $75-76$

Plant food, relation of, to soils........... 72

Playas, character and distribution of...... 10

Population, data on..... . ........... 18

\section{Q.}

Quaternary lakes, history of .

\section{R.}

Railroads, access by

Rainfall, records of.

relation of, to run-off

Reclamation, future of .

$80-81$

Reclamation law, provisions of.......... 70-71

Reclamation projects, descriptions of...... 70-71

Rhyolites, occurrence and character of ....

Rocks, character and age of . . . . . . . . . . 21-22 descriptions of ...................... $22-25$

structure of...................... 25-27

Run-off, relation of, to forests........... 36-37 relation of, to rainfall ............... 35-36

Russell, I. C., on southern Oregon ........ 30,47
Russell, I. C., work of

Page.

S.

Sagehrush, view of .................... 58

Salt bush, alkali removed by ............ 77

Saltpeter, occurrence of ................ $\quad 20$

Salts. See Alkali.

Sand dumes, character and distribution of. . 11 Sand Springs, description of.............. $\quad 66$ view of . . . . . . . . . .

Sandstone, occurrence of .............. 47

Scarps, description of .................. 9-10 origin of . . . . . . . . . . . relation of, to folds.................. 27

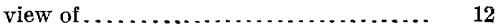

Settlements, description of .............. 18

Sevenmile Ridge, borings near........... 65

Shallow waters, occurrence of ...... 44-46,56-57

Silver Creek, description of .............. 31 flow of . . ....................... 34, 35, 40

Silver Lake, bluffs hordering............ 10 changes in . . . . . . . . . . . . . . . . . . 12, 37-38 drainage to......................... 31-32 evaporation from ................. 40, 41

flow near........................ 34 water of, character of ............... 14

Silver Lake (post-office), rainfall at. . .... 15, 39 temperature at..................... 15 wells at............................. 58

Silver Lake project, status of . . . . . . . $70-71$ Silver Lake Valley, artesian prospects in... 58-59 description of ..................... $57-59$

Sinks, character and distribution of....... 10 views of ......................... 10

Snyder, J. P., work of ................... 8

Soda, occurrence of .................... 20

Soils, analyses of $\ldots \ldots \ldots \ldots \ldots \ldots \ldots \ldots \ldots, 71$

constituents of..................... $73-75$

description of ...................... 71-78

plant food in....................... 72

See also Alkaline soils.

South Warner Valley, section of, flgure showing .................... 66

Spencer, J. W., on rock decay........... 44

Sprague River, drainage to............. 32

Springs, occurrence and character of...... 32 ,

$33,41-43,54-57,58,69-70$

view of . . . . . . . . . . . . . 58

Stock raising, industry of.............. 18-19

Stovepipe well, description of . .......... 78-80

Streams, deseriptions of . . . . . . . . . . . . . . . 31-37 supply from...................... 80

Structure, description of. . . . . . . . . . . 25-27 plates showing............. 50.60, Pocket. relation of, to ground water.......... 46-48

Sucker Flat, alkali at, test of............ 74 settlement at...................... $59-60$ wells on ........................... 65

Summer Lake, alkali at, test of.......... $\quad 74$ bluffs along........................ 10 changes in.......................... 38 drainage to ...................... 32,40 evaporation from ................ 40, 41-42 landslides near.................... 10 name of ......................... $\quad 20$ water of, character of ................ 13-14 


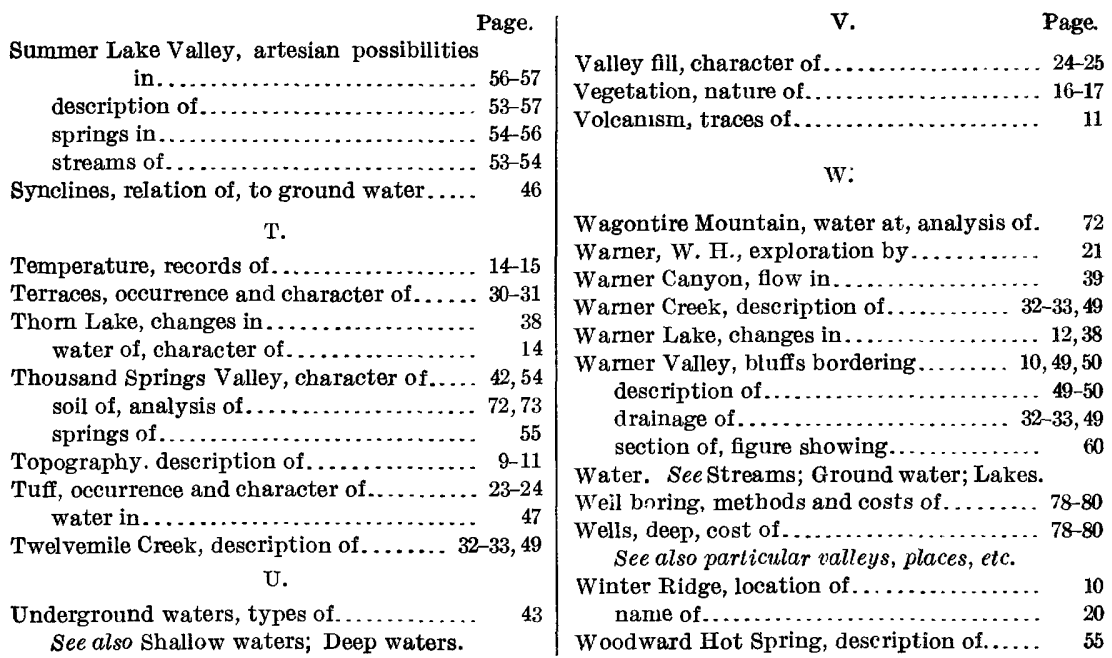



